\title{
Isotopic constraints on the genesis and evolution of basanitic lavas at
}

Haleakala, Island of Maui, Hawaii

Erin H. Phillips ${ }^{\mathrm{a}^{*}}$, Kenneth W.W. Sims ${ }^{\mathrm{a}}$, David R. Sherrod ${ }^{\mathrm{b}}$, Vincent J.M. Salters ${ }^{\mathrm{c}}$, Jurek Blusztajn $^{\mathrm{d}}$, Henrietta Dulai ${ }^{\mathrm{e}}$ 
ABSTRACT

2 To understand the dynamics of solid mantle upwelling and melting in the Hawaiian

3 plume, we present new major and trace element data, $\mathrm{Nd}, \mathrm{Sr}, \mathrm{Hf}$, and $\mathrm{Pb}$ isotopic 4 compositions, and ${ }^{238} \mathrm{U}_{-}{ }^{230} \mathrm{Th}_{-}{ }^{226} \mathrm{Ra}$ and ${ }^{235} \mathrm{U}_{-}{ }^{231} \mathrm{~Pa}^{2}{ }^{227} \mathrm{Ac}$ activities for 13 Haleakala

5 Crater nepheline normative basanites with ages ranging from $\sim 900$ to $4100 \mathrm{yr}$ B.P.. These

6 basanites of the Hana Volcanics exhibit an enrichment in incompatible trace elements and

7 a more depleted isotopic signature than similarly aged Hawaiian shield lavas from

8 Kilauea and Mauna Loa. Here we posit that as the Pacific lithosphere beneath the active 9 shield volcanoes moves away from the center of the Hawaiian plume, increased

10 incorporation of an intrinsic depleted component with relatively low ${ }^{206} \mathrm{~Pb} /{ }^{204} \mathrm{~Pb}$ produces

11 the source of the basanites of the Hana Volcanics. Haleakala Crater basanites have 12 average $\left({ }^{230} \mathrm{Th} /{ }^{238} \mathrm{U}\right)$ of $1.23(\mathrm{n}=13)$, average age-corrected $\left({ }^{226} \mathrm{Ra} /{ }^{230} \mathrm{Th}\right)$ of $1.25(\mathrm{n}=13)$,

13 and average $\left({ }^{231} \mathrm{~Pa} /{ }^{235} \mathrm{U}\right)$ of $1.67(\mathrm{n}=4)$, significantly higher than Kilauea and Mauna Loa

14 tholeiites. U-series modeling shows that solid mantle upwelling velocity for Haleakala

15 Crater basanites ranges from $\sim 0.7$ to $1.0 \mathrm{~cm} / \mathrm{yr}$, compared to $\sim 10$ to $20 \mathrm{~cm} / \mathrm{yr}$ for

16 tholeiites and $\sim 1$ to $2 \mathrm{~cm} / \mathrm{yr}$ for alkali basalts. These modeling results indicate that solid

17 mantle upwelling rates and porosity of the melting zone are lower for Hana Volcanics

18 basanites than for shield-stage tholeiites from Kilauea and Mauna Loa and alkali basalts

19 from Hualalai. The melting rate, which is directly proportional to both the solid mantle

20 upwelling rate and the degree of melting, is therefore greatest in the center of the

21 Hawaiian plume and lower on its periphery. Our results indicate that solid mantle

22 upwelling velocity is at least 10 times higher at the center of the plume than at its

23 periphery under Haleakala.

In order to interpret the dynamics and structure of the Hawaiian plume, it is necessary to

28 consider not only the predominant and well-studied shield-stage tholeiitic volcanism, but

29 also late-stage alkaline volcanism. These silica-undersaturated lavas tap magma from the

30 periphery of the plume as the Pacific lithosphere beneath the active shield volcanoes

31 moves away from the plume center. Shield-stage volcanism in Hawaii has been widely

32 studied since the work of the pioneering geologists H. T. Stearns and G. A. Macdonald in 
33 the 1940s. Haleakala, which is located on the island of Maui approximately $240 \mathrm{~km}$ to the 34 northwest of the inferred center of the hotspot (DePaolo and Stolper, 1996; Fig. 1),

35 presents an opportunity to study alkaline volcanism on the trailing edge of the Hawaiian

36 plume. The youngest $(<0.15-0.12 \mathrm{Ma})$ alkaline lavas from Haleakala are the Hana

37 Volcanics, which have been classified as rejuvenated stage volcanism (Bergmanis et al.,

38 2000; Stearns and Macdonald, 1942). This assertion, however, has been challenged by

39 Sherrod et al. (2003) based on the lack of a significant volcanic hiatus prior to eruption of

40 the Hana Volcanics and the geochemical similarity of the upper Kula and Hana

41 Volcanics. Regardless of their classification as either postshield stage or rejuvenated

42 stage volcanism, the youngest Haleakala lavas are highly alkaline, silica-undersaturated

43 basanites from the periphery of the Hawaiian plume. In this study, we will refer to these

44 lavas as postshield stage, consistent with Sherrod et al. (2003).

46 Here we examine a suite of 13 young basanitic lavas from Haleakala Crater using U-

47 series, $\mathrm{Nd}, \mathrm{Sr}, \mathrm{Hf}$, and $\mathrm{Pb}$ isotopes, and major- and trace-element abundances. These

48 silica-undersaturated basanites are ideal samples to study waning volcanism at the

49 Hawaiian hotspot as the Pacific plate moves to the northwest at a rate of 9-10 $\mathrm{cm} / \mathrm{yr}$

50 (Clague and Dalrymple, 1987). As such, these late-stage lavas provide clues on the

51 structure and geodynamical processes of the Hawaiian plume, the mantle sources of

52 alkaline lavas, and the processes that occur during melting and magma transport. By

53 comparing the major and trace element concentrations and isotope compositions of

54 known-age Haleakala basanites to young, similarly aged shield-stage tholeiites from

55 Kilauea and Mauna Loa and alkali basalts from Hualalai and Mauna Kea, we are able to

56 draw conclusions about the Hawaiian plume as a whole.

58 U-series isotopes $\left({ }^{238} \mathrm{U}_{-}{ }^{230} \mathrm{Th}^{-226} \mathrm{Ra}\right.$ and $\left.{ }^{235} \mathrm{U}_{-}{ }^{231} \mathrm{~Pa}\right)$ are especially useful in elucidating the

59 time scales of melting processes because the half-lives of ${ }^{230} \mathrm{Th}(75.4 \mathrm{kyr}),{ }^{226} \mathrm{Ra}(1.6$

$60 \mathrm{kyr})$, and ${ }^{231} \mathrm{~Pa}(32.8 \mathrm{kyr})$ are on the same order as the time scales of melt generation and

61 extraction. The small solid/liquid partition coefficients of $\mathrm{U}, \mathrm{Th}, \mathrm{Ra}$, and Pa make it

62 possible to glean information about the porosity of the melting zone and the rate of 
63 mantle upwelling (e.g., Beattie, 1993; Elkins et al., 2008; LaTourrette et al., 1993; Salters

64 and Longhi, 1999; Sims et al., 1999).

66 The source of Hawaiian lavas and the possible presence of a mafic component in the 67 mantle beneath Hawaii are topics of considerable debate. Some studies have implied that 68 partial melting of subducted oceanic plates, combined with mantle peridotite, play a role 69 in the generation of Hawaiian lavas (e.g., Hauri, 1996; Sobolev et al., 2005), while others

70 suggest that peridotite melting alone can produce the geochemical signatures observed 71 (e.g., Elkins et al., 2008; Sims et al., 1995, 1999; Stracke et al., 1999). Additionally, a

72 characteristic of late-stage alkaline lavas in Hawaii, such as Haleakala Crater basanites, is

73 their depleted $\mathrm{Nd}, \mathrm{Sr}$, and $\mathrm{Hf}$ isotope signatures that accompany enrichment in

74 incompatible trace elements (e.g., Chen and Frey, 1983; 1985). The origin of the depleted

75 signature is debated (e.g., Bizimis et al., 2013; Blichert-Toft et al., 1999; Chen and Frey,

76 1985; Cousens and Clague, 2015; Dixon et al., 2008; Frey et al., 2005; Garcia et al.,

77 2010; West and Leeman, 1987; Xu et al., 2005). Our new long-lived radioisotope data for

78 Haleakala Crater basanites answer questions regarding the mantle source of Hawaiian

79 lavas and, when combined with U-series isotopic data and major and trace element

80 geochemical data, provide a mapping of the upwelling structure of the Hawaiian plume.

Hawaii is considered by many to be the quintessential example of hotspot volcanism.

\section{GEOLOGIC BACKGROUND}

87 hotspot volcanism in the context of mantle plumes (e.g., Morgan, 1971; Wilson, 1963).

88 Three lines of evidence that support the existence of stationary mantle upwellings

89 beneath moving lithospheric plates are: (1) well-documented observations of age

90 progressive island chains, typified by the Hawaiian-Emperor islands and seamounts

91 (Wilson, 1963); (2) seismic imaging of low velocity zones at depth (e.g., Wolfe et al.,

92 2011; Zhao et al., 2013); and (3) geochemical models (Bourdon and Sims, 2003;

93 Pietruszka et al., 2001; Sims et al., 1999) and fluid mechanical models (Hauri et al., 
94 1994; Ribe and Christensen, 1999; Watson and McKenzie, 1991) that reveal rapidly

95 upwelling cores and more slowly upwelling peripheries.

97 The evolution of Hawaiian volcanoes comprises four stages, as recognized by Stearns 98 (1940) and described in detail by Clague (1987). Pre-shield stage volcanism consists of 99 basanite, alkali basalt, transitional basalt, and tholeiite. During the tholeiitic shield100 building stage, currently typified by Kilauea and Mauna Loa , $>95 \%$ of the volume of a

101 given volcano is erupted. Ensuing postshield stage volcanism consists primarily of 102 hawaiite, mugearite, benmoreite, and alkali basalt. The rejuvenated stage, also referred to 103 as post-erosional in early literature, is characterized by eruption of alkali basalt and 104 basanite and occurs after a period of quiescence, up to $\sim 2 \mathrm{~m} . \mathrm{y}$. after completion of the 105 postshield stage (Clague and Sherrod, 2014). Although numerous contributions have 106 focused on older postshield and rejuvenated lavas (e.g., Dixon et al., 2008; Garcia et al., 107 2010) and shield-stage lavas (e.g., Gaffney et al., 2004; Huang et al., 2005; Jackson et al., 108 2012; Nobra Silva et al., 2013; Ren et al., 2006, 2009; Weis et al., 2011), here our focus 109 is on young known-age Hawaiian lavas. Specifically we compare postshield basanites 110 from Haleakala with similarly aged (<6000 yr B.P.) tholeiites from Kilauea and Mauna

111 Loa and alkali basalts from Mauna Kea and Hualalai.

112

113 A detailed description of the petrology and geochemistry of Haleakala lavas is presented 114 by Macdonald and Powers (1968) and a general description of the geology of Haleakala 115 is given by Macdonald and Abbott (1970). Pre-shield stage lavas from Haleakala are 116 buried (Sherrod et al., 2003). The overlying lavas are divided into three units. The 117 Honomanu Basalt represents the shield-building stage and consists predominantly of 118 tholeiites. Its lavas are older than $\sim 0.93 \mathrm{Ma}$ (Chen et al., 1991). The postshield Kula 119 Volcanics unit consists mostly of alkali basalt and hawaiite, with rare mugearite and 120 ankaramite (Chen et al., 1990). These lavas erupted between $0.93 \mathrm{Ma}$ and 0.13-0.14 Ma 121 (Chen et al., 1991; Coe et al., 2004; Sherrod et al., 2003). The youngest unit at Haleakala 122 is the Hana Volcanics (Bergmanis et al., 2000; Sherrod et al., 2003), which is younger 123 than 0.15-0.12 Ma (Sherrod et al., 2003; Fig. 1). The Hana Volcanics unit is 124 predominantly basanite with scant alkali basalt. As previously stated, we refer here to the 
125 Hana Volcanics as postshield stage lavas, following the interpretation of Sherrod et al.

126 (2003), but emphasize that regardless of the classification of their eruptive stage, these

127 lavas are highly alkaline and erupted much farther from the plume center than shield-

128 stage Hawaiian tholeiites. West and Leeman (1987) note that there is no signficant

129 difference in the $\mathrm{Pb}$ or $\mathrm{Sr}$ isotopic composition between the Kula and Hana lavas,

130 consistent with the interpretation of Sherrod et al. (2003) that both units are postshield

131 lavas. The designation of eruptive stage has significance for hazard analysis due to the

132 difference in overall volume of erupted products between postshield and rejuvenated

133 stage volcanism, as well as the timing of an eruptive hiatus. The youngest lava flows on

134 Haleakala are the Keonehunehune and Kalua o Lapa flows. The Kalua o Lapa flow was

135 previously thought to have erupted in the mid to late 1700s (Oostdam, 1965; Stearns

136 and Macdonald, 1942;), but Sherrod et al. (2006) revised the combined age range of the

137 Keonehunehune and Kalua o Lapa flows to $330-460{ }^{14} \mathrm{C}$ yr B.P.

138

139

140

141 In this study we have analyzed 13 new basanite samples from Haleakala Crater, all

142 younger than $\sim 4100 \mathrm{yr}$ B.P. (Fig. 1; Table 1). Seven of these samples have radiocarbon

143 ages that range from $870 \pm 40 \mathrm{yr}$ to $4070 \pm 50 \mathrm{yr}$ B.P. (Sherrod and McGeehin, 1999). The

144 ages of the other six are bracketed by stratigraphic relations with dated lava flows, the

145 extent of weathering and soil development, and paleomagnetic directions in conjunction

146 with the paleosecular variation curve, and range from approximately 900 to $4000 \mathrm{yr}$ B.P.

147 (Sherrod et al., 2006). Knowledge of the ages of these samples is important for the

148 interpretation of their U-series disequilibria.

149

150 In previous studies by Sims et al. $(1995 ; 1999),{ }^{238} \mathrm{U}_{-}{ }^{230} \mathrm{Th}_{-}-{ }^{226} \mathrm{Ra}$ and ${ }^{235} \mathrm{U}_{-}{ }^{231} \mathrm{~Pa}$

151 disequilibria, and $\mathrm{Sr}$ and $\mathrm{Nd}$ isotope data for five samples from the southwest rift zone

152 (SWRZ) of Haleakala were reported. Hafnium isotopic data for the SWRZ samples are

153 from Stracke et al. (1999) and we present $\mathrm{Pb}$ data for these five samples in Table 3.

154 SWRZ and Haleakala Crater lavas are all part of the Hana Volcanics and are of similar

155 age and composition. Because of their similarity, the SWRZ samples and the new 
156 Haleakala Crater samples will be grouped together and referred to as the Hana Volcanics 157 in the subsequent text.

\section{ANALYTICAL METHODS}

Prior to analyses, phenocryst phases (primarily olivine, clinopyroxene, and plagioclase) were removed from rock chips by hand picking. Therefore, analyses are for groundmass only, which eliminates complications presented by possible xenocrystic material or

164 shallow fractional crystallization. Major and trace element concentrations were measured 165 at Boston University by inductively coupled plasma optical emission spectrometry (ICP166 OES) and inductively coupled plasma mass spectrometry (ICP-MS), respectively. See

167 Table 2 for details on analytical precision and analyses of rock standards.

169 Strontium, $\mathrm{Nd}$, and $\mathrm{Pb}$ isotopes were measured at Woods Hole Oceanographic Institution

170 (WHOI) with a Thermo Fisher Neptune multi-collector inductively coupled plasma mass 171 spectrometer (MC-ICP-MS). Samples were picked free of alteration and leached in

172 sequential batches of deionized water, $0.1 \mathrm{M}$ oxalic acid $+2 \% \mathrm{H}_{2} \mathrm{O}_{2}, 0.1 \mathrm{M} \mathrm{HCl}+2 \%$

$173 \mathrm{H}_{2} \mathrm{O}_{2}$, and deionized water. For $\mathrm{Sr}$ and $\mathrm{Nd}$ separation, powders were dissolved in 174 concentrated $\mathrm{HF}$ and $\mathrm{HClO}_{4}$, followed by three dry downs in $6.2 \mathrm{~N} \mathrm{HCl}$ to convert

175 fluorides to chlorides. Separation of $\mathrm{Sr}$ and $\mathrm{Nd}$ was carried out by conventional ion176 exchange chromatography using DOWEX 50 cation-exchange resin and then HDEHP-

177 coated Teflon powder (Taras and Hart, 1987). Lead was separated following the $\mathrm{HBr}-$

$178 \mathrm{HNO}_{3}$ procedure of Abouchami et al. (1999) using a single column pass. Hafnium

179 isotopes were analyzed using the Lamont Isolab 54 Secondary Ionization mass

180 spectrometer (England et al., 1992) at the National High Magnetic Field Laboratory (see

181 Salters et al., 2010). The Hf fraction was separated using the technique described by

182 Munker et al. (2001). See Table 3 and Hart and Blusztajn (2006), Hart et al. (2004;

183 2005), Munker et al. (2001) and Sims et al. (2008a) for further analytical details.

185 U-Th isotopic compositions were measured with a Thermo Fisher Neptune MC-ICP-MS

186 at WHOI. Thorium and U were separated and purified at WHOI using two anion

187 columns. Separate liquid aliquots of the same dissolution were used to measure $\mathrm{U}$ and $\mathrm{Th}$ 
concentrations. Concentrations were measured by isotope dilution using a Thermo Fisher

189 Element 2 high resolution sector-field ICP-MS at WHOI, with a peak jumping routine.

190 Samples were spiked with ${ }^{229} \mathrm{Th}$ and ${ }^{233} \mathrm{U}$ and equilibrated to attain ${ }^{232} \mathrm{Th} /{ }^{229} \mathrm{Th} \approx 30$ and

$191{ }^{238} \mathrm{U} /{ }^{233} \mathrm{U} \approx 10$. Further analytical details can be found in Table 4 and Ball et al. (2008),

192 and Sims et al. (2008b; 2008c).

194 The ${ }^{226} \mathrm{Ra}$ concentrations were analyzed by isotope dilution mass spectrometry at WHOI

195 with a Thermo Fisher Neptune MC-ICP-MS on separate aliquots from the same rock

196 dissolution. See Sims et al. (2008c) for complete details on the separation and

197 purification of $\mathrm{Ra}$ and additional analytical methods. ${ }^{231} \mathrm{~Pa}$ concentrations were measured

198 by isotope dilution on a Thermo Fisher Element 2 ICP-MS at WHOI. See Choi et al.

199 (2001), Pichat et al. (2004), Sims et al. (1999), Sims et al. (2002), and Sims et al. (2008c)

200 for further information about separation and purification of $\mathrm{Pa}$ and U-Pa methods.

201 Actinium was separated by extraction chromatographic techniques and analyzed by alpha

202 spectrometry at WHOI. See Dulaiova et al. (2013) for further details on separation and

203 analysis of ${ }^{227} \mathrm{Ac}$.

\subsection{Major and trace element geochemistry}

Haleakala Crater samples have $\mathrm{SiO}_{2}$ ranging from 41.9 to 46.8 wt. $\%$ and $\mathrm{K}_{2} \mathrm{O}+\mathrm{Na}_{2} \mathrm{O}$

\section{RESULTS} between 3.4 and 7.0 wt. \% (Table 2). Haleakala Crater and SWRZ basanites have lower

212 volcanoes (Figs. 2 and 3; Table 2). Haleakala lavas are also compared to Mauna Kea and

213 Hualalai lavas, which include alkali basalts, hawaiites and mugearites and Loihi lavas,

214 which are a combination of tholeiites and alkali basalts. For completeness, data for

215 Haleakala's shield-stage Honomanu Basalt, which is $>0.93 \mathrm{Ma}$, are also included in

216 selected figures. It is emphasized that our main goal is to compare Haleakala postshield

217 lavas with similarly aged (<6000 yr B.P.) shield-stage lavas from Kilauea, Mauna Loa,

218 Mauna Kea, and Hualalai, which are near the plume center. Haleakala's older shield-

219 stage Honomanu Basalt is not considered representative of recent plume material. 


\subsection{Sr-Nd-Hf-Pb Isotope Results}

222 Haleakala Crater samples have $\varepsilon_{\mathrm{Nd}}$ ranging from +7.3 to +8.5 , which encompass the $\varepsilon_{\mathrm{Nd}}$

223 values of the SWRZ samples (Table 3; Sims et al., 1995; 1999). ${ }^{87} \mathrm{Sr} /{ }^{86} \mathrm{Sr}$ for the Hana

224 Volcanics ranges from 0.70310 to 0.70333 (Table 3). Strontium isotopic compositions for

225 three of the SWRZ samples are slightly lower than for the new crater samples, whereas

226 the other two fall within the range of the crater samples (Sims et al., 1995; 1999).

227 Haleakala Crater and SWRZ basanites have relatively low ${ }^{87} \mathrm{Sr} /{ }^{86} \mathrm{Sr}$ and high $\varepsilon_{\mathrm{Nd}}$

228 compared to shield-stage Hawaiian lavas (Fig. 4). $\varepsilon_{\mathrm{Hf}}$ for seven crater lavas (Table 3) and

229 five SWRZ lavas (Stracke et al., 1999) ranges between +12.7 and +14.7 . Consistent with

230 the $\mathrm{Nd}$ and $\mathrm{Sr}$ isotopic data, $\varepsilon_{\mathrm{Hf}}$ values for the Hana Volcanics are higher than Hawaiian

231 shield-stage lavas (Fig. 5).

233 The Hana Volcanics samples range in ${ }^{206} \mathrm{~Pb} /{ }^{204} \mathrm{~Pb}$ from 18.166 to $18.324,{ }^{207} \mathrm{~Pb} /{ }^{204} \mathrm{~Pb}$

234 from 15.432 to 15.470 , and ${ }^{208} \mathrm{~Pb} /{ }^{204} \mathrm{~Pb}$ from 37.699 to 37.907 (Table 3; Fig. 6). Within

235 Hawaiian lavas, two trends in ${ }^{206} \mathrm{~Pb} /{ }^{204} \mathrm{~Pb}$ vs. ${ }^{208} \mathrm{~Pb} /{ }^{204} \mathrm{~Pb}$ space become apparent (Fig. 6a).

236 Compositional heterogeneity in Hawaiian lavas is not only present in a temporal sense

237 (i.e., pre-shield, shield, postshield, and rejuvenated stages), but also in a spatial sense,

238 recognized as distinct geochemical differences between shield lavas of Kea trend

239 volcanoes (including Mauna Kea, Kilauea, and Haleakala) and Loa trend volcanoes

240 (including Mauna Loa, Loihi, and Hualalai; Abouchami et al., 2005; Lassiter et al., 1996;

241 Weis et al., 2011). The compilation of data in Figure 6a depicts the Kea and Loa trends,

242 and shows that the basanites of the Hana Volcanics plot at the less radiogenic end of the

243 Kea trend, when compared strictly with similarly aged Hawaiian lavas. It should be noted

244 that older rejuvenated-stage lavas from East Molokai ( 0.34-0.57 Ma; Xu et al., 2005)

245 have $\mathrm{Pb}$ isotope compositions within the range of the Hana Volcanics. Some older

246 rejuvenated-stage lavas from Niihau (Dixon et al., 2008) and Kauai (Garcia et al., 2010)

247 also have $\mathrm{Pb}$ isotope compositions similar to the Hana Volcanics. In keeping with the aim

248 of our study, we plot only data for relatively young lavas with ages similar to the Hana

249 Volcanics.

\subsection{U-series results}


252 Basanites of the Hana Volcanics have $\left({ }^{230} \mathrm{Th} /{ }^{238} \mathrm{U}\right)$ from 1.18 to 1.32 for the 13 crater 253 samples (Table 4) and 5 SWRZ samples (Sims et al., 1995; 1999), with an average

$\left.254 \quad{ }^{230} \mathrm{Th} /{ }^{238} \mathrm{U}\right)$ of $1.24(\mathrm{n}=18)$. Age corrected $\left({ }^{226} \mathrm{Ra} /{ }^{230} \mathrm{Th}\right)$ is between 1.17 and 1.30 for the

255 Hana Volcanics samples (Table 4 and Sims et al., 1995; 1999), with an average of 1.26

256 ( $\mathrm{n}=18) .\left({ }^{231} \mathrm{~Pa} /{ }^{235} \mathrm{U}\right.$ ) for four Haleakala Crater basanite samples (Table 4) and four SWRZ

257 samples (Pickett and Murrell, 1997; Sims et al., 1995; 1999) ranges from 1.47 to 2.12,

258 with an average of $1.70(\mathrm{n}=9) .\left({ }^{227} \mathrm{Ac} /{ }^{231} \mathrm{~Pa}\right)$ was measured for four Haleakala Crater

259 samples (Table 4). All four are in equilibrium, which is as expected for samples of this

260 age $\left({ }^{227} \mathrm{Ac} \mathrm{t}_{1 / 2}=21.8 \mathrm{yr}\right)$. Sample HK-22 has $\left({ }^{231} \mathrm{~Pa} /{ }^{235} \mathrm{U}\right)$ of 2.12 , which is significantly

261 higher than other Hana Volcanics samples. The equilibrium $\left({ }^{227} \mathrm{Ac} /{ }^{231} \mathrm{~Pa}\right)$ for this sample

262 demonstrates that this high Pa value is robust and lends credence to both the $\mathrm{Pa}$ and Ac

263 methods. Additionally, this sample lies within the OIB field in $\left({ }^{230} \mathrm{Th} /{ }^{238} \mathrm{U}\right)$ versus

$264 \quad\left({ }^{231} \mathrm{~Pa} /{ }^{235} \mathrm{U}\right)$ space (Lundstrom et al., 2003; Sims et al., 2008c), albeit at the high

$265 \quad\left({ }^{231} \mathrm{~Pa} /{ }^{235} \mathrm{U}\right)$ end.

\subsection{Mantle Sources of Postshield Haleakala Lavas}

Late-stage alkaline Hawaiian lavas exhibit depleted isotopic signatures (relatively high

$\varepsilon_{\mathrm{Nd}}$ and $\varepsilon_{\mathrm{Hf}}$ and low ${ }^{87} \mathrm{Sr} /{ }^{86} \mathrm{Sr}$ ) but are enriched in highly incompatible trace elements

272 compared to shield-stage tholeiites (e.g., Bizimis et al., 2013; Chen and Frey, 1983; 1985;

273 Frey et al., 2005; Garcia et al., 2010; West and Leeman, 1987; Xu et al., 2005). This

274 seemingly contradictory observation can be explained by small degrees of partial melting,

275 which produces their characteristic basanitic compositions and light rare earth element

276 enrichments (Fig. 3). Several papers have debated the origin of the depleted isotopic

277 signature of alkaline Hawaiian lavas (e.g., Bryce et al., 2005; Frey et al., 2005; Lassiter et

278 al., 1996; Xu et al., 2005). One question in this debate is whether the depleted signatures

279 in postshield lavas are the result of mixing between the plume and the surrounding mantle

280 or the result of intrinsic heterogeneities within the plume. Early studies proposed the

281 depleted signatures were produced by increased mixing with a depleted mantle, or

282 MORB-like, component as a volcanic center moved away from the center of the

283 Hawaiian hotspot (e.g., Chen and Frey, 1985; West and Leeman, 1987). Chen and Frey 
284 (1985) argued that the enrichment of highly incompatible elements and the depleted Sr

285 and $\mathrm{Nd}$ isotopic signatures in younger alkaline Haleakala lavas compared to older

286 tholeiitic lavas requires a MORB component and a plume component. These authors

287 conclude that the depleted isotopic signatures of these late-stage alkaline lavas are the

288 result of decreased activity of the rising mantle plume and increased interaction between

289 plume derived material and the surrounding wall rock toward the periphery of the plume.

290 While the characteristic small degree of melting (F) of postshield Haleakala lavas is

291 generally agreed upon, others argue that the long-lived depleted component observed in

292 the isotopes is intrinsic to the Hawaiian plume (e.g., Bizimis et al., 2013; Fekiacova et al.,

293 2007; Frey et al., 2005; Garcia et al., 2010). In particular, Frey et al. (2005) show that

294 late-stage lavas are isotopically distinct from Pacific MORB in their $\mathrm{Pb}$ isotope ratios.

295 Further, it is debated whether the isotopic heterogeneity of the Hawaiian plume originates

296 in a deep thermal boundary layer and is vertically stretched on a large scale within the

297 plume or the isotopic heterogeneity takes the form of fertile plums dispersed throughout a

298 peridotite matrix (e.g., Abouchami et al., 2005; Hofmann and Farnetani, 2013).

299

300 Here we specifically focus on the mantle sources of the postshield lavas at Haleakala by

301 comparing their trace element and isotopic characteristics to similarly aged shield-stage

302 lavas. Although deciphering the large-scale chemical and lithological structure of the

303 Hawaiian plume is beyond the scope of this paper, understanding the mantle sources and

304 melting processes of young postshield alkaline lavas can provide perspective on the

305 entirety of the Hawaiian plume. Indeed, in comparison with other young Hawaiian lavas,

306 the Hana Volcanics have higher $\varepsilon_{\mathrm{Nd}}$ and $\varepsilon_{\mathrm{Hf}}$ and lower ${ }^{87} \mathrm{Sr} /{ }^{86} \mathrm{Sr}$ values, implying a greater

307 contribution from a depleted source in these postshield alkaline magmas (Figs. 4 and 5).

308 Haleakala Crater basanites analyzed in this study, as well as Haleakala SWRZ samples,

309 plot closer to the high $\varepsilon_{\mathrm{Nd}}$ and $\varepsilon_{\mathrm{Hf}}$ and low ${ }^{87} \mathrm{Sr} /{ }^{86} \mathrm{Sr}$ end of the array. These isotopic

310 signatures are consistent with increased involvement of a depleted component in late-

311 stage alkaline magmas as the lithosphere moves away from the center of the Hawaiian

312 hotspot.

313 
314 The $\mathrm{Pb}$ isotope ratios for the Hana Volcanics show more complicated relationships with 315 other young Hawaiian lavas (Fig. 6). As discussed in section 5.2, the Pb isotope ratios of 316 postshield Haleakala lavas are clearly within the spatial Kea trend (Abouchami et al.,

317 2005; Lassiter et al., 1996; Weis et al., 2011) and display non-radiogenic Pb isotope 318 compositions relative to other young Kea trend lavas plotted in Figure 6a. It is again 319 emphasized that the focus of our paper is to compare the Hana Volcanics to similarly 320 aged, young tholeiitic and alkali basalt lavas from near the plume center.

322 The Hana Volcanics show a positive correlation between ${ }^{87} \mathrm{Sr} /{ }^{86} \mathrm{Sr}$ and ${ }^{206} \mathrm{~Pb} /{ }^{204} \mathrm{~Pb}$, in 323 contrast to the overall negative trend of Kilauea and Mauna Loa tholeiites (Fig. 6b). West 324 and Leeman (1987) observed a similar trend for Haleakala postshield lavas and 325 concluded that two-component mixing is not a viable explanation for the isotopic and 326 geochemical characteristics of the different eruptive stages in Hawaii and that a three (or 327 more) component mixing model is required. They propose the Hawaiian mantle plume is 328 made up of primitive and enriched mantle components that are mixed to variable degrees 329 with a MORB-like component. We note, however, that the positive trend for postshield 330 lavas in $\mathrm{Sr}-\mathrm{Pb}$ isotope space (Figure 6b) does not point towards the average of the Pacific 331 MORB field (e.g., 9-10N EPR axial lavas; Sims et al., 2002), but could be explained by 332 mixing with the enriched lavas of the Garrett Transform (Wendt et al., 1999). Xu et al.

333 (2005) also discussed this negative trend in $\mathrm{Sr}-\mathrm{Pb}$ isotope space for postshield lavas from 334 Kea trend volcanoes and noted that they are influenced by a low ${ }^{206} \mathrm{~Pb} /{ }^{204} \mathrm{~Pb}$ and low

$335{ }^{87} \mathrm{Sr} /{ }^{86} \mathrm{Sr}$ component that clearly does not have a significant effect on the shield-stage 336 lavas.

338 To model mixing between Hawaiian plume material and a MORB-like component, we 339 have plotted $\mathrm{Sr}, \mathrm{Nd}$, and $\mathrm{Pb}$ isotopic ratios against the normalized $\mathrm{Ce} / \mathrm{Sm}$ ratio. (Fig. 7).

340 The utility of this comparison is that melting processes will affect the $\mathrm{Ce} / \mathrm{Sm}$ ratio but not 341 the isotope ratios. In this model, we assume Kilauea tholeiites, which along with 342 Haleakala are part of the Kea trend, are representative of the most recent eruptive 343 products from the center of the Hawaiian plume (Bryce et al. 2005; DePaolo and Stolper, 344 1996). Haleakala shield-stage lavas are much older ( $>0.9 \mathrm{Ma})$ and therefore are not 
345 considered representative of recent plume material. As illustrated in Figure 7 the Sr and

$346 \mathrm{Nd}$ isotopes can be explained by melting a two-component mixture of Hawaiian plume

347 material (represented by Kilauea tholeiites) and Pacific MORB. The ${ }^{208} \mathrm{~Pb} /{ }^{206} \mathrm{~Pb}$ data,

348 however, do not support two-component mixing because both Pacific MORB and

349 Hawaiian plume material have lower ${ }^{208} \mathrm{~Pb} /{ }^{206} \mathrm{~Pb}$ than Haleakala basanites. Varying the

350 degree of melting or the partition coefficients does not change this relationship. It is

351 permissible, however, that plume material mixed with either: (1) a high ${ }^{208} \mathrm{~Pb} /{ }^{206} \mathrm{~Pb}$

352 component $(>2.10)$ similar to the enriched MORB from the Garrett Transform (Wendt et

353 al., 1999); (2) the Depleted Rejuvenated Component (DRC) of Bizimis et al. (2013),

354 proposed to explain the isotopic compositions of Kaula lavas and pyroxenite xenoliths; or

355 (3) the Depleted Makapuu component (DMK) of Tanaka et al. (2002; 2008), proposed as

356 the depleted end member for Koolau shield lavas. In any case, the Pb isotope data suggest

357 that two-component mixing between plume material and Pacific MORB is not a viable

358 explanation for the formation of the initial solid composition of the Haleakala postshield

359 basanites; these data necessitate the involvement of a low ${ }^{206} \mathrm{~Pb} /{ }^{204} \mathrm{~Pb}\left(\right.$ high $\left.{ }^{208} \mathrm{~Pb} /{ }^{206} \mathrm{~Pb}\right)$

360 component. We argue that the most logical conclusion is that this low ${ }^{87} \mathrm{Sr} /{ }^{86} \mathrm{Sr}$, high

$361{ }^{208} \mathrm{~Pb} /{ }^{206} \mathrm{~Pb}$, and high ${ }^{143} \mathrm{Nd} /{ }^{144} \mathrm{Nd}$ component is an intrinsic part of the Hawaiian plume as

362 suggested by numerous studies including Bizimis et al. (2013), Fekiacova et al. (2007),

363 Frey et al. (2005), and Garcia et al. (2010).

365 This leads us to question the nature of this intrinsic component. While the heterogeneity

366 of the mantle is well established, the extent to which this long-lived isotopic

367 heterogeneity is the manifestation of lithological variability remains debated (e.g.,

368 Allègre and Turcotte, 1986; Donnelly et al., 2004; Hirschmann et al., 2003; Kogiso et al.,

369 2003; Sims et al., 2013; Waters et al., 2011; Workman et al., 2004). At a given pressure,

370 mafic lithologies (i.e., pyroxenites and eclogites) have lower solidus temperatures than

371 peridotites, and the difference in temperature between the solidus and liquidus of

372 pyroxenite is less than for peridotite. Pyroxenites thus produce more melt than peridotites

373 and clearly their presence in the melting region can significantly affect the geochemistry

374 of erupted lavas (e.g., Elkins et al., 2008, 2011, 2014; Hirschmann and Stolper, 1996;

375 Hirschmann et al., 2003; Ito and Mahoney, 2005; Pertermann and Hirschmann, 1999; 
376 Prytulak and Elliott, 2009; Rudge et al., 2013; Sims et al., 2013; Stracke and Bourdon,

377 2009; Waters et al., 2011). As noted above, there are clearly multiple components in the

378 source of Hawaiian lavas, indicated by long-lived radiogenic isotopes, and some studies

379 provide strong evidence for the influence of pelagic sediments in the source of Hawaiian

380 lavas (Blichert-Toft et al., 1999; Nielsen et al., 2006). Some research argues for

381 lithological heterogeneity in the Hawaiian source (e.g., Bianco et al., 2005; Hauri, 1996;

382 Jackson et al., 2012; Lassiter et al., 2000; Pietruszka et al., 2013), even including the

383 argument that the Hawaiian source is olivine free (Sobolov et al., 2005). Others maintain

384 that pyroxenite is not necessary to produce the geochemical signatures of Hawaiian lavas

385 (e.g., Elkins et al., 2008; Marske et al., 2008; Matzen et al., 2013; Pietruszka et al., 2006;

386 Salters et al., 2006; Sims et al., 1995; 1999; Stracke et al., 1999; Wagner and Grove,

387 1998; Wang and Gaetani, 2008).

389 U-Th-Ra and U-Pa disequilibria, coupled with other geochemical constraints, are

390 potentially sensitive indicators of lithological variability in the mantle source (Elkins et

391 al., 2008; Prytulak and Elliott, 2009; Stracke et al., 2006; Stracke et al., 1999; Waters et

392 al., 2011). In this context we use our U-Th-Ra and U-Pa data and major and trace element

393 data to examine lithological heterogeneity in the Hawaiian plume source. Our new data

394 from the Hana Volcanics are consistent with the conclusions of Stracke et al. (1999), who

395 use $\mathrm{Hf}, \mathrm{Nd}$, and Th isotopes to argue that mafic lithologies are unlikely in the source of

396 Hawaiian lavas. Stracke et al. (2006) point out that there is a wide range in the

397 experimentally and theoretically determined values of the partition coefficients of $\mathrm{U}$

398 relative to $\mathrm{Th}\left(\mathrm{D}_{\mathrm{U}} / \mathrm{D}_{\mathrm{Th}}\right)$ in pyroxenitic and eclogitic sources (e.g., Pertermann and

399 Hirschmann, 2002; Pertermann et al., 2004; van Westrenen et al., 1999) obfuscating the

400 distinction between pyroxenitic and peridotitic melts. In contrast to these findings, more

401 recent partitioning studies by Elkins et al. (2008) established that the partition

402 coefficients for $\mathrm{U}$ and $\mathrm{Th}$ in garnet pyroxenites are significantly different than in

403 peridotites. Differences in the fusibility of peridotites and pyroxenites can lead to

404 significant differences in not only the U-series data but also in major and trace element

405 compositions (Elkins et al., 2008, 2011, 2014; Prytulak and Elliott, 2009; Rudge et al.

406 2013; Sims et al., 2013; Waters et al., 2011). 
408 As outlined below, our data clearly show that a mixed lithological source beneath Hawaii

409 is not required to explain the U-series or other geochemical data for the Hana Volcanics.

410 In fact, when using the pyroxenitic partition coefficients of Elkins et al. (2008), we do not

411 see convergence in the modeled melting parameters for U-Th, U-Pa and Th- Ra

412 disequilibria for the Hana Volcanics basanites (Table 5 and further discussed below in

413 section 6.2). While some U-series studies demonstrate the need for pyroxenitic

414 components in the source of MORB (e.g., Elkins et al., 2011; 2014; Waters et al., 2011),

415 many OIB studies show that U-series data can be successfully modeled using a peridotitic

416 source (e.g., Elkins et al., 2008; Prytulak and Elliott, 2009; Sims et al., 1999).

418 Select trace element ratios can potentially be indicative of the presence of recycled mafic

419 components because of their contrasting solubilities and compatibilities in residual phases

420 during subduction (Kay, 1980; Pearce and Stern, 2006; Yogodzinski et al., 2015). The

421 bulk partition coefficient for $\mathrm{Ba}$ in pyroxenite is an order of magnitude larger than in

422 peridotite, whereas Ta is similar in both (Stracke and Bourdon, 2009), meaning that

423 pyroxenitic lithologies retain $\mathrm{Ba}$ in their residual solids much more readily than

424 peridotites. We posit that this partitioning difference in $\mathrm{Ba} / \mathrm{Ta}$, coupled with their

425 respective behaviors during subduction will produce lower $\mathrm{Ba} / \mathrm{Ta}$ ratios in erupted lavas

426 containing a significant pyroxenitic component in their source. Isotopically depleted

427 postshield lavas from Haleakala, including the Hana Volcanics, have high $\mathrm{Ba} / \mathrm{Ta}$ ratios

428 compared to most other young Hawaiian lavas (Fig. 8). The likelihood of a recycled

429 mafic component in the source of Hana Volcanics is therefore less likely than in the

430 source of Kilauea or Mauna Loa shield-stage tholeiites. It is noted that some trace

431 element ratios such as $\mathrm{Sr} / \mathrm{Nd}$ have also been used to discriminate between peridotitic and

432 pyroxenitic sources. Small degrees of melting in Haleakala postshield lavas, evidenced

433 by their enrichment in highly incompatible elements (Fig. 3), could have an overriding

434 effect on trace element ratios such as $\mathrm{Sr} / \mathrm{Nd}$ and mask the effect that source heterogeneity

435 would have on these ratios. We therefore posit the $\mathrm{Ba} / \mathrm{Ta}$ ratio as a good indicator of the

436 higher likelihood of a pyroxenitic component in shield-stage lavas as opposed to

437 postshield Haleakala lavas because of the combined effect of the traceable $\mathrm{Ba} / \mathrm{Ta}$ 
composition of subducted oceanic crust and the difference in the $\mathrm{Ba} / \mathrm{Ta}$ partition

439 coefficients between peridotite and pyroxenite. If a pyroxenitic component is present in

440 the Hawaiian plume, it is likely preferentially melted during the shield-stage, prior to

441 eruption of postshield Haleakala lavas. Bizimis et al. (2013) also reached a similar

442 conclusion in their study of rejuvenated lavas at Kaula. In addition to the $\mathrm{Ba} / \mathrm{Ta}$ ratios,

443 the depleted isotopic signature of Haleakala postshield lavas supports the argument

444 against a pyroxenitic component in their source (Fig. 8). If derived from a recycled mafic

445 component, the Haleakala postshield lavas would be expected to have a more enriched

446 isotopic signature.

$448 \quad 6.2$ Solid mantle upwelling rates and buoyancy flux on the periphery of the

449 Hawaiian plume

450 Because the half-life of ${ }^{226} \mathrm{Ra}(\sim 1.6 \mathrm{kyr})$ is comparable to the estimated transport time for

451 Hawaiian melts to rise through the melt column, $\left({ }^{226} \mathrm{Ra} /{ }^{230} \mathrm{Th}\right)$ data for Hawaiian basalts

452 require models that consider the time-scales of melt generation and extraction. Dynamic

453 melting (McKenzie, 1985) and chromatographic porous flow (Spiegelman and Elliott,

454 1993) are two end member fluid dynamical models invoked to explain U-series

455 disequilibria. In dynamic melting, trapped melts remain in equilibrium with the solid

456 until a critical porosity is attained, at which point melt in excess of this critical porosity is

457 extracted from the melting region. In chromatographic porous flow, melt and solid

458 maintain chemical equilibrium in the melt column and U-series disequilibria are the result

459 of the more compatible parent nuclides travelling more slowly through the melt column

460 than their respective daughter nuclides. The parent nuclides decay, leading to excesses of

461 daughter nuclides, which are exemplified by $\left({ }^{230} \mathrm{Th} /{ }^{238} \mathrm{U}\right)$ and $\left({ }^{226} \mathrm{Ra} /{ }^{230} \mathrm{Th}\right)$ greater than 1

462 in many MORB and OIB basalts. Sims et al. (1999) investigated a limited suite of

463 Hawaiian samples using ${ }^{238} \mathrm{U}_{-}^{230} \mathrm{Th}_{-}{ }^{226} \mathrm{Ra}$ and ${ }^{235} \mathrm{U}_{-}{ }^{231} \mathrm{~Pa}$ disequilibria and found that both

464 chromatographic porous flow (Spiegelman and Elliott, 1993) and dynamic melting

465 (McKenzie, 1985) models can explain the observed data and suggest that solid mantle

466 upwelling rate and maximum porosity of the melting zone are greater for tholeiites than

467 for alkali basalts and basanites and that solid mantle upwelling velocity decreases with

468 distance from the center of the Hawaiian plume, consistent with the geodynamical 
472 The Haleakala Crater data presented here are consistent with those of Sims et al. (1995;

473 1999); namely, they exhibit higher $\left({ }^{230} \mathrm{Th} /{ }^{238} \mathrm{U}\right),\left({ }^{226} \mathrm{Ra} /{ }^{230} \mathrm{Th}\right)$, and $\left({ }^{231} \mathrm{~Pa} /{ }^{235} \mathrm{U}\right)$

474 disequilibria values than Hawaiian tholeiites and alkali basalts. ${ }^{230}$ Th excesses indicate

475 melting of a source containing residual garnet. Dynamic melting models, in combination

476 with $\mathrm{Ra}$ and Th disequilibria, suggest melting rates between $1 \times 10^{-5}$ and $1 \times 10^{-4} \mathrm{~kg} \mathrm{~m}^{-3} \mathrm{yr}^{-1}$

477 with melt zone porosities between $0.2 \%$ and $0.5 \%$ for Haleakala basanites (Fig. 9). Some

478 Pa disequilibria data lie outside the dynamic melting model grid shown in Figure 9 but

479 are generally consistent with these conclusions. These melting rates and porosities for

480 Haleakala basanites are lower than those for shield-stage tholeiites from Kilauea and

481 Mauna Loa, which are greater than $2 \times 10^{-4} \mathrm{~kg} \mathrm{~m}^{-3} \mathrm{yr}^{-1}$ and between about $0.2 \%$ and $2 \%$,

482 respectively.

484 In dynamic melting models, the melt extraction velocity cannot be calculated explicitly 485 and the melt transport time is assumed to be very short compared to the half-life of the 486 shortest-lived daughter $\left({ }^{226} \mathrm{Ra} ; \mathrm{t}_{1 / 2} \sim 1.6 \mathrm{kyr}\right)$, whereas in the chromatographic porous flow 487 model melt extraction velocity relative to solid mantle upwelling is calculated explicitly 488 (e.g., Sims et al., 1999; Spiegelman and Elliott, 1993). The importance of melt transport 489 time has been highlighted in several studies including Sims et al. (2002) for EMORB 490 from the East Pacific Rise, Stracke et al. (2006) for Icelandic basalts from Theistareykir, 491 and Weatherly and Katz (2016) for MORB.

493 At Hawaii, however, data for young basalts presented here and in Sims et al. (1995;

494 1999) can be successfully modeled with dynamic melting by varying only the porosity

495 and solid mantle upwelling velocity. As a first order constraint, it is clear that ${ }^{226} \mathrm{Ra}$

496 excesses require melt transport times much less than 8,000 years (i.e., $<$ five half-lives of

$497{ }^{226} \mathrm{Ra}$ ). While we cannot argue against transport times on the order of $<1 \mathrm{kyr}$ for the Hana

498 Volcanics, there is no indication in the data that such a correction is necessary. Some

499 OIBs, such as young lavas (<300 yr B.P.) from the Canary Islands, have higher Ra 
500 excesses than the Hana Volcanics $\left(\left({ }^{226} \mathrm{Ra}{ }^{230} \mathrm{Th}\right)\right.$ up to 1.8; Lundstrom et al., 2003), but

501 they also have overall higher ${ }^{231} \mathrm{~Pa}$ excess $\left(\left({ }^{231} \mathrm{~Pa} /{ }^{235} \mathrm{U}\right)\right.$ up to 2.0$)$. Melt transport on these

502 timescales would not have an appreciable effect on $\left({ }^{231} \mathrm{~Pa} /{ }^{238} \mathrm{U}\right)$ disequilibria because the

503 half-life of ${ }^{231} \mathrm{~Pa}$ is $\sim 32.8 \mathrm{kyr}$. Therefore, in the absence of further evidence that melt

504 transport time was appreciable relative to the half-life of ${ }^{226} \mathrm{Ra}$, we do not further consider

505 it in our dynamic melting models. Additionally, if melt transport was long enough to

506 appreciably affect ${ }^{226} \mathrm{Ra} /{ }^{230} \mathrm{Th}$ disequilibrium, the initial ${ }^{226} \mathrm{Ra}$ excesses would have been

507 even larger than those measured, requiring even lower porosities. In any case, solid

508 mantle upwelling rate would be little affected because variations in this parameter are

509 mostly associated with $\left({ }^{230} \mathrm{Th} /{ }^{238} \mathrm{U}\right)$ disequilibria. As highlighted in previous studies (e.g.,

510 Sims et al., 1999, 2002; Stracke et al., 2006) uncertainties in partition coefficients are

511 significant and are the limiting factor in these calculations.

513 Chromatographic modeling results (using the UserCalc program of Spiegelman, 2000)

514 imply maximum porosity of the melt zone of $\sim 0.5-0.6 \%$ for tholeiites, $\sim 0.2-0.3 \%$ for

515 alkali basalts, and $\sim 0.1-0.3 \%$ for basanites and modeled solid mantle upwelling velocities

516 of $\sim 10-20 \mathrm{~cm} / \mathrm{yr}$ for tholeiites, $\sim 1-2 \mathrm{~cm} / \mathrm{yr}$ for alkali basalts, and $\sim 0.7-1.0 \mathrm{~cm} / \mathrm{yr}$ for

517 basanites (Fig. 10). In Figure 10, uncertainties on the average disequilibria values shown

518 are signified with one standard deviation error envelopes. For pre-shield volcanism at

519 Loihi, Sims et al. (1999) model the solid mantle upwelling velocity of Loihi tholeiites to

520 be between $\sim 15$ and $35 \mathrm{~cm} / \mathrm{yr}$ and alkali basalts between $\sim 8$ and $10 \mathrm{~cm} / \mathrm{yr}$ based on

$521 \quad\left({ }^{230} \mathrm{Th} /{ }^{238} \mathrm{U}\right)$ and $\left({ }^{231} \mathrm{~Pa} /{ }^{235} \mathrm{U}\right)$ disequilibria. Pietruszka et al. (2011) model upwelling rates

522 at Loihi of $\sim 5-6 \mathrm{~cm} / \mathrm{yr}$, utilizing their $\left({ }^{230} \mathrm{Th} /{ }^{238} \mathrm{U}\right)$ data and $\left({ }^{226} \mathrm{Ra} /{ }^{230} \mathrm{Th}\right)$ data of Rubin et

523 al. (2005).

525 The following equations display the relationships between the critical parameters

526 considered in the chromatographic porous flow model (see Spiegelman and Elliott, 1993

527 and Appendix 1 in Sims et al., 1999).

$$
w=\Gamma d \rho l \phi 2
$$

529 where $w$ is the average melt velocity, $\Gamma$ is the melting rate, $d$ is the length of the melt 530 column, $\rho_{l}$ is the density of the melt, and $\phi$ is the porosity. The melting rate is defined as: 
532 where $\mathrm{W}$ is the solid upwelling velocity and $F_{\max }$ is the maximum melt fraction. These 533 equations serve to demonstrate that the melting rate is directly proportional to both the 534 solid upwelling rate $(W)$ and the degree of melting $\left(F_{\max } / d\right)$. As previously shown, 535 Haleakala postshield basanites exhibit higher $\left({ }^{230} \mathrm{Th} /{ }^{238} \mathrm{U}\right)$ than other young Hawaiian 536 lavas. $\left({ }^{230} \mathrm{Th} /{ }^{238} \mathrm{U}\right)$ is correlated with other trace element ratios, including $\mathrm{Sm} / \mathrm{Nd}$ as 537 represented by $\alpha_{\mathrm{Sm} / \mathrm{Nd}}$ (Fig. 11), where $\alpha_{\mathrm{Sm} / \mathrm{Nd}}$ represents $\mathrm{Sm} / \mathrm{Nd}$ fractionation and is 538 defined as $(\mathrm{Sm} / \mathrm{Nd})_{\text {magma }} /(\mathrm{Sm} / \mathrm{Nd})_{\text {source. }}$ Lavas of the Hana Volcanics show a greater 539 degree of $\mathrm{Sm} / \mathrm{Nd}$ fractionation than Hawaiian tholeiites and alkali basalts, demonstrating 540 that $\left({ }^{230} \mathrm{Th} /{ }^{238} \mathrm{U}\right)$ and $\mathrm{Sm} / \mathrm{Nd}$ fractionation vary with composition and this variability in 541 trace element ratio fractionation and major element composition can be attributed to 542 varying degrees of partial melting (Sims et al., 1995; 1999). We emphasize that the 543 basanitic composition (high $\mathrm{Na}_{2} \mathrm{O}+\mathrm{K}_{2} \mathrm{O}$ ) and enrichment in highly incompatible trace 544 elements require that the Haleakala postshield lavas are the result of small degrees of 545 partial melting. The correlation between $\mathrm{U} / \mathrm{Th}$ fractionation, $\mathrm{Sm} / \mathrm{Nd}$ fractionation, and 546 major element indices, including $\mathrm{Na}_{8.0}$ and the silica saturation index, in Hawaiian data is 547 parameterized by Sims et al. (1995). In the buoyant Hawaiian plume, elemental U/Th 548 fractionation plays an important role in generating $\left({ }^{230} \mathrm{Th} /{ }^{238} \mathrm{U}\right)$ disequilibrium, whereas 549 in less buoyant plumes ${ }^{230}$ Th ingrowth is more significant (Elliott, 1997; Sims and Hart, 550 2006; Sims et al., 1995; 1999). In this regard, we note that the lower upwelling rate at the 551 plume edge increases the amount of ingrown ${ }^{230} \mathrm{Th}$, but the postshield basanitic lavas 552 from Haleakala are also lower degree melts than the shield-stage tholeiites, and so we 553 argue that both of these factors are influencing the large ${ }^{230} \mathrm{Th}$ excesses in the Haleakala 554 basanites. As indicated by equation (2) above, the small degrees of partial melting of the

555 Haleakala basanites coupled with low melting rates, produce high $\left({ }^{230} \mathrm{Th} /{ }^{238} \mathrm{U}\right)$

556 disequilibria. Our models show that the solid mantle upwelling rates for Haleakala 557 postshield lavas are at least 10 times lower than for shield-stage tholeiites from Kilauea 558 and Mauna Loa.

560 In this modeling context we note that utilization of $\mathrm{D}$ values for a garnet pyroxenite 561 source from Elkins et al. (2008) did not converge on a unique solution for Haleakala 
562 basanites or Hualalai alkali basalts in chromatographic porous flow models (Table 5).

563 For Kilauea and Mauna Loa tholeiites, the upper end of the range of D values for garnet

564 pyroxenites from Elkins et al. (2008) resulted in no model convergence, whereas the

565 lower end of the range resulted in modeled solid mantle upwelling velocity of 90-200

$566 \mathrm{~cm} / \mathrm{yr}$ and porosity of 5-7\%. As discussed in the previous section, the range in D values

567 for $\mathrm{U}$ and $\mathrm{Th}$ in mafic lithologies complicates using $\mathrm{U}$-series disequilibria to definitively

568 discriminate between peridotitic, pyroxenitic, and eclogitic sources (Stracke et al., 2006).

569 Although some variation is apparent in the modeled porosity and solid mantle upwelling

570 velocity based on different $\mathrm{D}$ values for garnet peridotite sources (Table 5), there is a

571 robust difference between the solid mantle upwelling rates and porosities for shield-stage

572 tholeiites from Kilauea and Mauna Loa and the postshield basanites from Haleakala.

574 Because $\left({ }^{230} \mathrm{Th} /{ }^{238} \mathrm{U}\right),\left({ }^{226} \mathrm{Ra} /{ }^{230} \mathrm{Th}\right)$, and $\left({ }^{231} \mathrm{~Pa}{ }^{235} \mathrm{U}\right)$ disequilibrium is partially a function

575 of mantle upwelling rate (equation 2 above), the buoyancy flux (B) of a mantle plume can

576 be calculated from the following expression (Bourdon et al., 1998; Bourdon and Sims,

577 2003):

578

579 where $\mu$ is the viscosity and $\mathrm{W}$ is the upwelling rate. The buoyancy flux for a plume of

580 entirely thermal origin as defined by Sleep (1990) and discussed by Chabaux and Allègre 581 (1994) is:

$$
B=\rho m \propto \Delta T Q p
$$

583 where $\rho_{\mathrm{m}}$ is the density of the mantle $\left(3300 \mathrm{~kg} / \mathrm{m}^{3}\right), \alpha$ is the thermal expansion coefficient $584\left(3 \times 10^{-5}{ }^{\circ} \mathrm{C}^{-1}\right), \Delta \mathrm{T}$ is the excess temperature of the plume, and $\mathrm{Q}_{\mathrm{p}}$ is the volume flux of the 585 plume. Chabaux and Allègre (1994) demonstrate an inverse relationship between

$586\left({ }^{230} \mathrm{Th} /{ }^{238} \mathrm{U}\right)$ disequilibria and buoyancy flux. Bourdon et al. (2006) suggest a similar 587 inverse relationship between $\left({ }^{231} \mathrm{~Pa} /{ }^{235} \mathrm{U}\right)$ disequilibria and buoyancy flux.

589 The buoyancy flux of the Hawaiian swell, or the topographic anomaly related to the 590 hotspot, is estimated by Sleep (1990) as $8.7 \mathrm{Mg} / \mathrm{s}$. Based on three-dimensional numerical 591 modeling, Ribe and Christensen (1994) propose that the buoyancy flux of the Hawaiian 592 plume itself is $4.1 \mathrm{Mg} / \mathrm{s}$. Ribe and Christensen (1999) further refine this estimate by 
593 taking into account both the thermal buoyancy flux and the depletion buoyancy flux to

594 arrive at a total buoyancy flux of $4.0 \mathrm{Mg} / \mathrm{s}$.

596 We note that buoyancy flux estimates do not take into consideration differences in 597 upwelling rates between the center of the plume and its periphery. Using the U-series 598 data presented here for postshield lavas at Haleakala and the relationships between U599 series disequilibria and buoyancy flux presented in Bourdon et al. (2006), we estimate the 600 buoyancy flux at the trailing edge of the Hawaiian plume. Using the average Hana 601 Volcanics $\left({ }^{230} \mathrm{Th} /{ }^{238} \mathrm{U}\right)$ of $1.24(\mathrm{n}=18 ; 0.0451 \sigma$ std dev $)$, the average $\left({ }^{231} \mathrm{~Pa} /{ }^{235} \mathrm{U}\right)$ of 1.70

$602(\mathrm{n}=9 ; 0.1901 \sigma \mathrm{std} \mathrm{dev})$, and assuming a viscosity of $5 \times 10^{20} \mathrm{~Pa} \mathrm{~s}$, a buoyancy flux of $\sim 1.5$ $603 \mathrm{Mg} / \mathrm{s}$ is inferred based on $\left({ }^{230} \mathrm{Th} /{ }^{238} \mathrm{U}\right)$ and $\sim 2.2 \mathrm{Mg} / \mathrm{s}$ based on $\left({ }^{231} \mathrm{~Pa} /{ }^{235} \mathrm{U}\right)$. Bourdon et 604 al. (2006) also model buoyancy flux based on excess temperature and predict the excess 605 temperature at the top of the Hawaiian plume to be $200^{\circ} \mathrm{C}$. Putirka (2008) estimates the 606 excess temperature of the Hawaiian plume as $290^{\circ} \mathrm{C}$. Assuming an excess temperature 607 between $200^{\circ} \mathrm{C}$ and $300^{\circ} \mathrm{C}$, a buoyancy flux of $\sim 1.5-2.2 \mathrm{Mg} / \mathrm{s}$ is inferred from both $608\left({ }^{230} \mathrm{Th} /{ }^{238} \mathrm{U}\right)$ and $\left({ }^{231} \mathrm{~Pa} /{ }^{235} \mathrm{U}\right)$ (see Fig. 4 in Bourdon et al., 2006). In summary, the 609 buoyancy flux of the postshield Haleakala lavas deduced from our U-series isotope data 610 and the models of Bourdon et al. (2006) is between $\sim 1.5$ and $2.2 \mathrm{Mg} / \mathrm{s}$. Clearly there are

611 large uncertainties associated with the parameters discussed here, but this buoyancy flux

612 estimate for the periphery of the Hawaiian plume is approximately one half of the

613 buoyancy flux value of $4.1 \mathrm{Mg} / \mathrm{s}$ for the plume as a whole calculated by Ribe and

614 Christensen (1994). Undoubtedly the buoyancy flux is greatest at the center of the plume;

615 however, it is necessary to integrate the buoyancy flux over the whole of a mantle plume,

616 including the slower upwelling periphery, in order to arrive at a reliable estimate for

617 overall buoyancy flux.

\subsection{An updated model for the dynamics of the Hawaiian plume}

The preceding discussion leads to the following observations and inferences regarding

622 Haleakala postshield lavas and their relation to young shield-stage lavas from the plume

623 center: (1) Relative to young Hawaiian shield-stage lavas, Haleakala postshield lavas

624 have low $\mathrm{SiO}_{2}$ contents and high abundances of incompatible elements (2) Haleakala 
625 postshield lavas have more depleted isotopic signatures than shield-stage lavas (3)

626 Haleakala postshield lavas, in comparison to shield-stage lavas, are the result of lower

627 melting rates, which are a function of both lower solid mantle upwelling velocities and

628 smaller degrees of melting (see equation 2) (4) Haleakala postshield lavas melted from a

629 source containing residual garnet.

631 Our dataset provides an opportunity to incorporate constraints on melting processes and

632 sources from major and trace element data, long-lived radiogenic isotope data, and U-

633 series data. While the major and trace elements and long-lived radiogenic isotopes

634 constrain extents of melting and source variability, the U-series data presented here allow

635 us to examine the variation in melting rates across the plume. As we have emphasized

636 above, this melting rate is a function of both $\mathrm{F}_{\max } / \mathrm{d}$ and solid mantle upwelling rates (W).

637 Our modeling shows that the Hana volcanics are the manifestation of both relatively

638 small degrees of melting and lower solid mantle upwelling rates. The solid mantle

639 upwelling rates of Haleakala basanites are at least 10 times lower than shield-stage

640 tholeiites from Kilauea and Mauna Loa. We can therefore use the U-series disequilibria

641 to compare solid mantle upwelling rate to other parameters including the degree of

642 melting and the composition of the source of different Hawaiian lavas. Figure 12 shows

643 comparisons of some relevant geochemical parameters with $\left({ }^{230} \mathrm{Th} /{ }^{238} \mathrm{U}\right),\left({ }^{226} \mathrm{Ra} /{ }^{230} \mathrm{Th}\right)$,

644 and $\left({ }^{231} \mathrm{~Pa} /{ }^{235} \mathrm{U}\right) . \mathrm{SiO}_{2}$ is lower in basanites from Haleakala Crater and $\mathrm{SWRZ}$ than in

645 other young Hawaiian volcanoes. There is a general negative correlation between $\mathrm{SiO}_{2}$

646 and $\left({ }^{230} \mathrm{Th} /{ }^{238} \mathrm{U}\right)$ and $\left({ }^{231} \mathrm{~Pa} /{ }^{235} \mathrm{U}\right)$ and also between $\mathrm{SiO}_{2}$ and $\left({ }^{226} \mathrm{Ra} /{ }^{230} \mathrm{Th}\right)$ if Hualalai data

647 are not considered. The La/Sm ratio is considered a good indicator of the degree of partial

648 melting because of the significantly different partition coefficients of La and Sm

$649\left(\mathrm{D}_{\mathrm{La}}<\mathrm{D}_{\mathrm{Sm}}\right)$. Haleakala basanites display higher $\mathrm{La} / \mathrm{Sm}$ than most other young Hawaiian

650 lavas, with the shield-stage lavas of Kilauea and Mauna Loa having the lowest $\mathrm{La} / \mathrm{Sm}$

651 ratios within the young Hawaiian lavas examined here. La/Sm ratios correlate well with

$652\left({ }^{230} \mathrm{Th} /{ }^{238} \mathrm{U}\right)$ and $\left({ }^{231} \mathrm{~Pa} /{ }^{235} \mathrm{U}\right)$, suggesting that lower solid mantle upwelling velocities are

653 coupled with smaller degrees of partial melting. We use the $\mathrm{Ba} / \mathrm{Ta}$ ratio to investigate the

654 possible presence of a recycled mafic component in the source of Hawaiian lavas. As

655 previously discussed, Haleakala basanites have higher $\mathrm{Ba} / \mathrm{Ta}$ ratios than most shield- 
656 stage Kilauea and Mauna Loa lavas, suggesting that a recycled mafic component is a 657 more likely possibility in the shield-stage lavas than in postshield lavas. Ba/Ta ratios in

658 some Hualalai lavas are as high as or higher than Haleakala basanites, so the $\mathrm{Ba} / \mathrm{Ta}$ ratio

659 does not distinguish between the sources of Hualalai and Haleakala lavas. In general,

660 lower solid mantle upwelling rates correspond to higher $\mathrm{Ba} / \mathrm{Ta}$ ratios, and therefore to a

661 more peridotitic source. Last, $\varepsilon_{\mathrm{Nd}}$ is positively correlated with U-series disequilibria

662 ratios, indicating that more depleted sources are coupled with lower solid mantle

663 upwelling rates.

665 The postshield Hana Volcanics represent the waning stages of melting of the Hawaiian 666 plume as the Pacific lithosphere moves to the northwest. They are the manifestation of 667 low melting rates (smaller degrees of melting and lower upwelling rates) of a silica668 undersaturated depleted source within the plume. As the distance from the plume center 669 increases, rates of solid mantle upwelling decrease by at least a factor of 10. Finally, if a 670 mafic component is present within the Hawaiian plume, it likely was exhausted during 671 shield-stage volcanism before postshield volcanism commenced at Haleakala.

\section{CONCLUSIONS}

677 Hawaiian plume and to better understand dynamics of mantle upwelling. Geochemical

678 and isotopic analyses of thirteen new samples from Haleakala Crater with ages of less

679 than $\sim 4100$ yr B.P. confirm that these late-stage lavas have high alkali contents and

680 enriched incompatible element concentrations, confirming that they are the result of small

681 degrees of partial melting compared to shield-stage tholeiites.

682 - Haleakala Crater basanites have higher $\varepsilon_{\mathrm{Nd}}$ and $\varepsilon_{\mathrm{Hf}}$ and lower ${ }^{87} \mathrm{Sr} /{ }^{86} \mathrm{Sr}$ isotopic values

683 than shield-stage Hawaiian tholeiites, implying a greater contribution from a depleted

684 source on the periphery of the plume. The $\mathrm{Pb}$ isotopes show that the depleted component

685 is unlike Pacific MORB and likely is an intrinsic component to the Hawaiian plume.

686 - The high $\mathrm{Ba} / \mathrm{Ta}$ ratios, coupled with the depleted isotopic signature, of the Hana

687 Volcanics imply that pyroxenitic or eclogitic lithologies are unlikely in their source. If a 
mafic component is present within the Hawaiian plume, it is likely exhausted during shield-stage melting, leaving only a depleted peridotitic component to melt during postshield volcanism.

- Average $\left({ }^{230} \mathrm{Th} /{ }^{238} \mathrm{U}\right),\left({ }^{226} \mathrm{Ra} /{ }^{230} \mathrm{Th}\right)$, and $\left({ }^{231} \mathrm{~Pa} /{ }^{235} \mathrm{U}\right)$ for basanites from Haleakala are all measurably higher than shield-stage tholeiites from Kilauea and Mauna Loa. Dynamic melting models show that the Haleakala basanites result from lower melting rates (which

694 are directly proportional to both the solid mantle upwelling rate and the degree of

695 melting) than the tholeiites. Chromatographic porous flow modeling also confirms that

696 solid mantle upwelling rates and porosity of the melting zone are lower on the periphery

697 of the Hawaiian plume than at the plume center. Specifically, Haleakala Crater basanites

698 have solid mantle upwelling velocities of $0.7-1.0 \mathrm{~cm} / \mathrm{yr}$, whereas shield-stage tholeiites have solid mantle upwelling velocities of 10-20 cm/yr.

\section{ACKNOWLEDGEMENTS}

Funding for this project was provided by NSF grants EAR-0001924 and EAR-9909473 to KWWS. The University of Wyoming Department of Geology and Geophysics, the Wyoming NASA Space Grant Consortium, and the Uranium-series Symposium 2014 provided travel funds to EHP to present results of this research. Matthew Jull is thanked for assistance with fieldwork and Glenn Gaetani is acknowledged for providing thoughtful insights. We thank Terry Plank and colleagues at Boston University for analyzing the major and trace element concentrations. Associate Editor Fred Frey, Andreas Stracke, Aaron Pietruszka, and an anonymous reviewer provided constructive reviews that significantly improved the manuscript. Marc Norman and Shichun Huang are also thanked for editorial handling.

\section{REFERENCES}

Abouchami W., Galer S. J. G., and Koschinsky A. (1999) Pb and Nd isotopes in NE Atlantic Fe-Mn crusts: proxies for trace metal paleosources and paleocean circulation. Geochim. Cosmochim. Acta 63, 1489-1505.

Abouchami W., Hofmann A. W., Galer S. J. G., Frey F. A., Eisele J., and Feigenson M. (2005) Lead isotopes reveal bilateral asymmetry and vertical continuity in the Hawaiian mantle plume. Nature 434, 851-856.

Adam J. and Green T. (2006) Trace element partitioning between mica- and amphibole-bearing garnet lherzolite and hydrous basanitic melt: 1. Experimental results and the investigation of controls on partitioning behaviour. Contrib. Mineral. Petrol. 152, 1-17. 
Allègre C. J. and Turcotte, D. L. (1986) Implications of a two-component marble-cake mantle. Nature 323, $123-127$.

Andersen M. B., Elliott T., Freymuth H., Sims K. W. W., Niu Y., and Kelley K. A. (2015) The terrestrial uranium isotope cycle. Nature 517, 356-359.

Ball, L., Sims K. W. W., and Schwieters J. (2008) Measurement of ${ }^{234} \mathrm{U} /{ }^{238} \mathrm{U}$ and ${ }^{230} \mathrm{Th} /{ }^{232} \mathrm{Th}$ in volcanic rocks using the Neptune MC-ICP-MS. J. Anal. Atom. Spectrom. 23, 173-180. doi: 10.1039/b703193a.

Beattie P. (1993) Uranium-thorium disequilibria and partitioning on melting of garnet peridotite. Nature 363, 63-65.

Bergmanis E. C., Sinton J. M. and Trusdell F. A. (2000) Rejuvenated volcanism along the southwest rift zone, East Maui, Hawai'i. Bull. Volcanol 62, 239-255.

Bianco T. A., Ito G., Becker J. M. and Garcia M.O. (2005) Secondary Hawaiian volcanism formed by flexural arch decompression. Geochem. Geophys. Geosyst. 6.

Bizimis M., Salters V. J. M., Garcia, M. O. and Norman M. D. (2013) The composition and distribution of the rejuvenated component across the Hawaiian plume: Hf-Nd-Sr-Pb isotope systematics of Kaula lavas and pyroxenite xenoliths. Geochem. Geophys. Geosyst. 14.

Blichert-Toft J., Frey F. A. and Albarède F. (1999) Hf Isotope Evidence for Pelagic Sediments in the Source of Hawaiian Basalts. Science 285, 879-882.

Bourdon B., Joron J.-L., Claude-Ivanaj C. and Allegre C. J. (1998) U-Th-Pa-Ra systematics for the Grande Comore volcanics: melting processes in an upwelling plume. Earth Planet. Sci. Lett. 164, 119-133.

Bourdon B., Ribe N. M., Stracke A., Saal A. E. and Turner S. P. (2006) Insights into the dynamics of mantle plumes from uranium-series geochemistry. Nature 444, 713-717.

Bourdon B. and Sims K. W. W. (2003). U-series constraints on intraplate magmatism. In: Uranium Series Geochemistry, Reviews in Mineralogy and Geochemistry 52 (eds. B. Bourdon, G. M. Henderson, C. C. Lundstrom, and S. P. Turner), 215-253. doi: 10.2113/0520215.

Bryce J. G., DePaolo D. J., and Lassiter J. C., (2005) Geochemical structure of the Hawaiian plume: Sr, Nd, and Os isotopes in the $2.8 \mathrm{~km}$ HSDP-2 section of Mauna Kea volcano. Geochem. Geophys. Geosyst. 6.

Chabaux F. and Allègre C. J. (1994) ${ }^{238} \mathrm{U}^{230}{ }^{23} \mathrm{~h}-{ }^{226} \mathrm{Ra}$ disequilibria in volcanics: A new insight into melting conditions. Earth Planet. Sci. Lett. 126, 61-74.

Cheng H., Edwards, R. L., Hoff J., Gallup C. D., Richards D. A., and Asmerom Y. (2000) The half-lives of uranium-234 and thorium-230. Chem. Geol., 169, 17-33.

Chen, C.-Y. and Frey F. A. (1983) Origin of Hawaiian tholeiite and alkalic basalt. Nature 302, 785-789.

Chen C.-Y. and Frey F. A. (1985) Trace element and isotopic geochemistry of lavas from Haleakala Volcano, East Maui, Hawaii: Implications for the origin of Hawaiian basalts. J. Geophys. Res. 90, 8743-8768.

Chen C.-Y., Frey F. A. and Garcia M. O. (1990) Evolution of alkalic lavas at Haleakala Volcano, east Maui, Hawaii. Contrib. Mineral. Petrol. 105, 197-218.

Chen C.-Y., Frey F. A., Garcia M. O., Dalrymple G. B. and Hart S. R. (1991) The tholeiite to alkalic basalt transition at Haleakala Volcano, Maui, Hawaii. Contrib. Mineral. Petrol. 106, 183-200.

Choi M.S., Francois R., Sims K. W. W., Bacon M. P., Leger-Brown S., Fleer A. P., Ball L., Schneider D., and Pichat S. (2001) Rapid determination of ${ }^{230} \mathrm{Th}$ and ${ }^{231} \mathrm{~Pa}$ in seawater by desolvated micronebulization Inductively Coupled Plasma magnetic sector mass spectrometry. Mar. Chem. 76, 99112.

Clague D. A. (1987) Hawaiian alkaline volcanism. In: Alkaline Igneous Rocks, Geological Society Special Publication No. 30 (ed. J. G. Fitton and B. G. J. Upton). Blackwell Scientific Publications, Oxford.

Clague D. A. and Dalrymple G. B. (1987) The Hawaiian-Emperor volcanic chain Part 1. Geologic evolution. USGS Prof. Pap. 1350, 5-54.

Clague D. A. and Sherrod D. R. (2014) Growth and Degradation of Hawaiian Volcanoes. In: Characteristics of Hawaiian Volcanoes (eds. M. P. Poland, T. J. Takahashi, and C. M. Landowski). U.S. Geological Survey Professional Paper 1801, 97-146.

Coe R. S., Singer B. S., Pringle M. S. and Zhao X. (2004) Matuyama-Brunhes reversal and Kamikatsura event on Maui: paleomagnetic directions, ${ }^{40} \mathrm{Ar} /{ }^{39} \mathrm{Ar}$ ages and implications. Earth Planet. Sci. Lett. 222, 667-684.

Cohen A. S. and O’Nions R. K., 1993. Melting rates beneath Hawaii: Evidence from uranium series isotopes in recent lavas. Earth Planet. Sci. Lett. 120, 169-175. 
Cohen A. S., O’Nions R. K. and Kurz M. D. (1996) Chemical and isotopic variations in Mauna Loa tholeiites. Earth Planet. Sci. Lett. 143, 111-124.

Cooper K. M., Reid M. R., Murrell M. T., and Clague D. A. (2001) Crystal and magma residence at Kilauea Volcano, Hawaii: ${ }^{230} \mathrm{Th}-{ }^{226} \mathrm{Ra}$ dating of the 1955 east rift eruption. Earth Planet. Sci. Lett. 184, 703-718.

Cousens B. L. and Clague D. A. (2015) Shield to Rejuvenated Stage Volcanism on Kauai and Niihau, Hawaiian Islands. J. Petrol. 56, 1547-1584.

DePaolo D. J. (1988) Neodymium Isotope Geochemistry. Springer-Verlag.

DePaolo D. J. and Stolper E. M. (1996) Models of Hawaiian volcano growth and plume structure: Implications of results from the Hawaii Scientific Drilling Project. J. Geophys. Res. 101, 1164311654.

Dixon J., Clague D. A., Cousens B., Monsalve M. L., and Uhl J. (2008) Carbonatite and silicate melt metasomatism of the mantle surrounding the Hawaiian plume: Evidence from volatiles, trace elements, and radiogenic isotopes in rejuvenated-stage lavas from Niihau, Hawaii. Geochem. Geophys. Geosyst. 9.

Donnelly K. E., Goldstein S. L., Langmuir C. H., and Spiegelman M. (2004) Origin of enriched ocean ridge basalts and implications for mantle dynamics. Earth Planet. Sci. Lett. 226, 347-366.

Dulaiova H., Sims K. W. W., Charette M. A., Prytulak J., and Blusztajn J. S. (2013) A new method for the determination of low-level actinium-227 in geological samples. J. RadioAnalytical and Nuclear Chem. 296, 279-283.

Elliott T. (1997) Fractionation of U and Th during mantle melting: a reprise. Chem. Geol. 139, 165-183.

Elkins L. J., Gaetani G. A. and Sims K. W. W. (2008) Partitioning of U and Th during garnet pyroxenite partial melting: Constraints on the source of alkaline ocean island basalts. Earth Planet. Sci. Lett. 265, 270-286.

Elkins L. J., Sims K. W. W., Prytulak J., Blichert-Toft J., Elliott T., Blusztajn J., Fretzdorff S., Reagan M., Haase K., Humphris S., and Schilling J.-G. (2014) Melt generation beneath Arctic Ridges: Implications from U decay series disequilibria in the Mohns, Knipovich, and Gakkel Ridges. Geochim. Cosmochim. Acta 127, 140-170.

Elkins L. J., Sims K. W. W., Prytulak J., Elliott T., Mattielli N., Blichert-Toft J., Blusztajn J., Dunbar, N., Devey C., Mertz D. F., Schilling J.-G., Murrell M. (2011) Understanding melt generation beneath the slow-spreading Kolbeinsey Ridge using ${ }^{238} \mathrm{U},{ }^{230} \mathrm{Th}$, and ${ }^{231} \mathrm{~Pa}$ excesses. Geochim. Cosmochim. Acta 75, 6300-6329.

England J. G., Zindler A., Reisberg L. C., Rubenstone J. L., Salters V., Marcantonio F., Bourdon B., Brueckner H., Turner P. J., Weaver S., and Read P. (1992) The Lamont-Doherty Geological Observatory Isolab 54 isotope ratio mass spectrometer. Int. J. Mass Spec. Ion Proc. 121, 201-240.

Fekiacova Z., Abouchami W., Galer S. J. G., Garcia M. O., and Hofmann A. W. (2007) Origin and temporal evolution of Ko'olau Volcano, Hawai'i: Inferences from isotope data on the Ko'olau Scientific Drilling Project (KSDP), the Honolulu Volcanics and ODP Site 843. Earth Planet. Sci. Lett. 261, 65-83.

Frey F. A., Huang S., Blichert-Toft J., Regelous M. and Boyet M. (2005) Origin of depleted components in basalt related to the Hawaiian hot spot: Evidence from isotopic and incompatible element ratios. Geochem. Geophys. Geosyst. 6.

Gaffney A. M., Nelson B. K., and Blichert-Toft J. (2004) Geochemical Constraints on the Role of Oceanic Lithosphere in Intra-Volcano Heterogeneity at West Maui, Hawaii. J. Petrol. 45, 1663-1687.

Garcia M. O., Jorgenson B. A., Mahoney J. J., Ito E., and Irving A. J. (1993) An Evaluation of Temporal Geochemical Evolution of Loihi Summit Lavas: Results from Alvin Submersible Dives. J. Geophys. Res. 98, 537-550.

Garcia M. O., Pietruszka A. J. and Rhodes J. M. (2003) A Petrologic Perspective of Kilauea Volcano's Summit Magma Reservoir. J. Petrol 44, 2313-2339.

Garcia M. O., Pietruszka A. J., Rhodes J. M., and Swanson K. (2000) Magmatic Processes During the Prolonged Pu'u O’o Eruption of Kilauea Volcano, Hawaii. J. Petrol. 41, 967-990.

Garcia M. O., Rhodes J. M., Trusdell F. A., and Pietruszka A. J. (1996) Petrology of lavas from the Puu Oo eruption of Kilauea Volcano: III. The Kupaianaha episode (1986-1992). Bull. Volcanol 58, 359-379.

Garcia M. O., Rubin K. H., Norman M. D., Rhodes J. M., Graham D. W., Muenow D. W., and Spencer K. (1998) Petrology and geochronology of basalt breccia from the 1996 earthquake swarm of Loihi seamount, Hawaii: magmatic history of its 1996 eruption. Bull. Volcanol 59, 577-592. 
Garcia M. O., Swinnard L., Weis D., Greene A. R., Tagami T., Sano H., and Gandy C. E. (2010) Petrology, Geochemistry and Geochronology of Kaua'i lavas over 4.5 Myr: Implications for the Origin of Rejuvenated Volcanism and the Evolution of the Hawaiian Plume. J. Petrol. 51, 1507-1540.

Hart S. R., Ball L., and Jackson M. (2005) Sr isotopes by laser ablation PIMMS: application to CPX from Samoan peridotite xenoliths. WHOI Plasma Facility Open File Technical Report, vol. 11. www.whoi.edu/science/GG/people/shart/open_file.htm

Hart S. R. and Blusztajn J. (2006) Age and geochemistry of the mafic sills, ODP site 1276, New Foundland margin. Chem. Geol. 235, 222-237. doi: 10.1016/j.chemgeo.2006.07.001.

Hart S. R., Hauri E. H., Oschmann L. A. and Whitehead J. A. (1992) Mantle Plumes and Entrainment: Isotopic Evidence. Science 256, 517-520.

Hart S. R., Workman R. K., Ball L., and Blusztajn J. (2004) High precision Pb isotope techniques from the WHOI NEPTUNE PIMMS. WHOI Plasma Facility Open File Technical Report, vol. 10. www.whoi.edu/science/GG/people/shart/open_file.htm

Hauri E. H. (1996) Major-element variability in the Hawaiian mantle plume. Nature 382, 415-419.

Hauri E. H., Whitehead J. A. and Hart S. R. (1994) Fluid dynamic and geochemical aspects of entrainment in mantle plumes. J. Geophys. Res. 99, 24275-24300.

Hirschmann M. M., Kogiso T., Baker M. B. and Stolper E. M. (2003) Alkalic magmas generated by partial melting of garnet pyroxenite. Geology 31, 481-484.

Hirschmann M. M. and Stolper E. M. (1996) A possible role for garnet pyroxenite in the origin of the "garnet signature" in MORB. Contrib. Mineral. Petrol. 124, 185-208.

Hofmann A. W. and Farnetani C.G. (2013) Two views of Hawaiian plume structure. Geochem. Geophys. Geosyst. 14.

Holden N. E. (1990) Total half-lives for selected nuclides. Pure Appl. Chem. 62, 941-958.

Huang S., Frey F. A., Blichert-Toft J., Fodor R. V., Bauer G. R. and Xu G. (2005) Enriched components in the Hawaiian plume: Evidence from Kahoolawe Volcano, Hawaii. Geochem. Geophys. Geosyst. 6.

Ito G. and Mahoney J. J. (2005) Flow and melting of a heterogeneous mantle: 1. Method and importance to the geochemistry of ocean island and mid-ocean ridge basalts. Earth Planet. Sci. Lett. 230, 29-46.

Jackson M. G., Weis D. and Huang S. (2012) Major element variations in Hawaiian shield lavas: Source features and perspectives from global ocean island basalt (OIB) systematics. Geochem. Geophys. Geosyst. 13.

Jaffey A. H., Flynn K. F., Glendenin L. E., Bentley W. C., and Essling A. M. (1971) Precision measurement of half-lives and specific activities of ${ }^{235} \mathrm{U}$ and ${ }^{238} \mathrm{U}$, Phys. Rev. C, 4, 1889-1906.

Kay R. W. (1980) Volcanic Arc Magmas: Implications of a melting-mixing model for element recycling in the crust-upper mantle system. J. Geol. 88, 497-522.

Kelley K. A., Plank T., Ludden J., and Staudigel H. (2003) Composition of altered oceanic crust at ODP sites 801 and 1149. Geochem. Geophys. Geosyst. 4, doi: 10.1029/2002GC000435.

Klein E. M. and Langmuir C. H. (1987) Global Correlations of Ocean Ridge Basalt Chemistry with Axial Depth and Crustal Thickness. J. Geophys. Res. 92, 8089-8115.

Kogiso T., Hirschmann M. M. and Frost D. J. (2003) High-pressure partial melting of garnet pyroxenite: possible mafic lithologies in the source of ocean island basalts. Earth Planet. Sci. Lett. 216, 603-617.

Lassiter J. C., DePaolo D. J. and Tatsumoto M. (1996) Isotopic evolution of Mauna Kea volcano: Results from the initial phase of the Hawaii Scientific Drilling Project. J. Geophys. Res. 101, 11769-11780.

Lassiter J. C., Hauri E. H., Reiners P. W. and Garcia M. O. (2000) Generation of Hawaiian post-erosional lavas by melting of a mixed lherzolite/pyroxenite source. Earth Planet. Sci. Lett. 178, 269-284.

LaTourrette T. Z., Kennedy A. K. and Wasserburg G. J. (1993) U-Th fractionation by garnet-evidence for a deep source and rapid rise by oceanic basalts. Science 261, 739-742.

Le Roux L. J. and Glendenin L. E. (1963) Half-life of ${ }^{232}$ Th, Proc. Natl. Meet. Nucl. Energy, 83.

Lundstrom C. C., Hoernle K. and Gill J. (2003) U-series disequilibria in volcanic rocks from the Canary Islands: Plume versus lithospheric melting. Geochim. Cosmochim. Acta 67, 4153-4177.

Lundstrom C. C., Shaw H. F., Ryerson F. J., Phinney D. L., Gill J. B. and Williams, Q. (1994) Compositional controls on the partitioning of $\mathrm{U}, \mathrm{Th}, \mathrm{Ba}, \mathrm{Pb}, \mathrm{Sr}$ and $\mathrm{Zr}$ between clinopyroxene and haplobasaltic melts: implications for uranium series disequilibria in basalts. Earth Planet. Sci. Lett. 128, 407-423.

Macdonald G. A. and Abbott A. T. (1970) Volcanoes in the sea; the geology of Hawaii. University of Hawaii Press, Honolulu. 
Macdonald G. A. and Powers H. A. (1968) A Further Contribution to the Petrology of Haleakala Volcano, Hawaii. Geol. Soc. Am. Bull. 79, 877-888.

Marske J. P., Garcia M. O., Pietruszka A. J., Rhodes J. M., and Norman M. D. (2008) Geochemical Variations during Kīlauea's Pu'u 'Ō'ō Eruption Reveal a Fine-scale Mixture of Mantle Heterogeneities within the Hawaiian Plume. J. Petrol. 49, 1297-1318.

Matzen A. K., Baker M. B., Beckett J. R., and Stolper E. M. (2013) The Temperature and Pressure Dependence of Nickel Partitioning between Olivine and Silicate Melt. J. Petrol. 54, 2521-2545.

McDonough W. F. and Sun S.-s. (1995) The composition of the Earth. Chem. Geol. 120, 223-253.

McKay G. A. (1989) Partitioning of REE between major silicate minerals and basaltic melts. In: Geochemistry and Mineralogy of REE (eds. B. R. Lipin and G. A. McKay). Reviews in Mineralogy 21, 45-75.

McKenzie D. (1985) ${ }^{230} \mathrm{Th}^{238} \mathrm{U}$ disequilibrium and the melting processes beneath ridge axes. Earth Planet. Sci. Lett. 72, 149-157.

Morgan W. J. (1971) Convection Plumes in the Lower Mantle. Nature 230, 42-43.

Munker C., Weyer, S., Scherer E., and Mezger, K. (2001) Separation of high field strength elements (Nb, $\mathrm{Ta}, \mathrm{Zr}, \mathrm{Hf}$ ) and Lu from rock samples for MC-ICPMS measurements. Geochem. Geophys. Geosyst. 2.

Nielsen S. G., Rehkämper M., Norman M. D., Halliday A. N., and Harrison D. (2006) Thallium isotopic evidence for ferromanganese sediments in the mantle source of Hawaiian basalts. Nature 439, 314317.

Nobra Silva I. G., Weis D., and Scoates J. S. (2013) Isotopic systematics of the early Mauna Kea shield phase and insight into the deep mantle beneath the Pacific Ocean. Geochem. Geophys. Geosyst. 14.

Oostdam B. L. (1965) Age of lava flows on Haleakala, Maui, Hawaii. Geol. Soc. Am. Bull. 76, 393-394.

Pearce J. A. and Stern R. J. (2006) Origin of Back-Arc Basin Magmas: Trace Element and Isotope Perspectives. In: Back-Arc Spreading Systems: Geological, Biological, Chemical, and Physical Interactions; Geophysical Monograph 166, 63-86.

Pertermann M. and Hirschmann M. M. (1999) Partial melting experiments on a MORB-like pyroxenite between 2 and $3 \mathrm{GPa}$ : Constraints on the presence of pyroxenite in basalt source regions from solidus location and melting rate. $J$. Geophys. Res. 108.

Pertermann M. and Hirschmann M.M. (2002) Trace-element partitioning between vacancy-rich eclogitic clinopyroxene and silicate melt. Am Mineral 87, 1365-1376.

Pertermann M., Hirschmann M.M., Hametner K., Günther D., and Schmidt M.W. (2004) Experimental determination of trace element partitioning between garnet and silica-rich liquid during anhydrous partial melting of MORB-like eclogite. Geochem. Geophys. Geosyst. 5, doi:10.1029/2003GC000638.

Pichat S., Sims K. W. W., François R., McManus J. F., Brown Leger S., and Albarède F. (2004) Lower export production during glacial periods in the equatorial Pacific as derived from $\left({ }^{231} \mathrm{~Pa} /{ }^{230} \mathrm{Th}\right)$ measurements in deep-sea sediments. Paleoceanography 19, PA4023, doi: 10.1029/2003PA000994.

Pickett, D. A. and Murrell M. T. (1997) Observations of ${ }^{231} \mathrm{~Pa} /{ }^{235} \mathrm{U}$ disequilibrium in volcanic rocks. Earth Planet. Sci. Lett. 148, 259-271.

Pietruszka A. J. and Garcia M. O. (1999) The size and shape of Kilauea Volcano's summit magma storage reservoir: a geochemical probe. Earth Planet. Sci. Lett. 167, 311-320.

Pietruszka A. J., Hauri E. H., Carlson R. W., and Garcia M. O. (2006) Remelting of recently depleted mantle within the Hawaiian plume inferred from the ${ }^{226} \mathrm{Ra}^{230}{ }^{230}-{ }^{238} \mathrm{U}$ disequilibria of $\mathrm{Pu}^{\prime} \mathrm{u}$ ' $\overline{\mathrm{O}}$ 'o eruption lavas. Earth Planet. Sci. Lett. 244, 155-169.

Pietruszka A. J., Keyes M. J., Duncan J. A., Hauri E. H., Carlson R. W., and Garcia M. O. (2011) Excesses of seawater-derived ${ }^{234} \mathrm{U}$ in volcanic glasses from Loihi Seamount due to crustal contamination. Earth Planet. Sci. Lett. 304, 280-289.

Pietruszka A. J., Norman M. D., Garcia M. O., Marske J. P., and Burns D. H. (2013) Chemical heterogeneity in the Hawaiian mantle plume from the alteration and dehydration of recycled oceanic crust. Earth Planet. Sci. Lett. 361, 298-309.

Pietruszka A. J., Rubin K. H. and Garcia M. O. $(2001){ }^{226} \mathrm{Ra}-{ }^{230} \mathrm{Th}-{ }^{238} \mathrm{U}$ disequilibria of historical Kilauea lavas (1790-1982) and the dynamics of mantle melting within the Hawaiian plume. Earth Planet. Sci. Lett. 186, 15-31. 
Prytulak J. and Elliott T. (2009) Determining melt productivity of mantle sources from ${ }^{238} \mathrm{U}_{-}^{230} \mathrm{Th}$ and ${ }^{235} \mathrm{U}-$ ${ }^{231} \mathrm{~Pa}$ disequilibria; an example from Pico Island, Azores. Geochim. Cosmochim. Acta 73, $2103-$ 2122.

Putirka K. (2008) Excess temperatures at ocean islands: Implications for mantle layering and convection. Geology 36, 283-286.

Ren Z.-Y., Hanyu T., Miyazaki T., Chang Q., Kawabata H., Takahashi T., Hirahara Y., Nichols A. R. L. and Tatsumi Y. (2009) Geochemical Differences of the Hawaiian Shield Lavas: Implications for Melting Process in the Heterogeneous Hawaiian Plume. J. Petrol. 50, 1553-1573.

Ren Z.-Y., Shibata T., Yoshikawa M., Johnson K. T. M., and Takahashi E. (2006) Isotope compositions of the submarine Hana Ridge lavas, Haleakala volcano, Hawaii: Implications for source compositions, melting process and the structure of the Hawaiian plume. J. Petrol. 47, 255-275.

Ribe N. M. and Christensen U.R. (1994) Three-dimensional modeling of plume-lithosphere interaction. $J$. Geophys. Res. 99, 669-682.

Ribe N. M. and Christensen U. R. (1999) The dynamical origin of Hawaiian volcanism. Earth Planet. Sci. Lett. 171, 517-531.

Robert J., Miranda C. F., and Muxart R. (1969) Mesure de la periode du protactinium-231 par microcalorimetrie, Radiochim. Acta, 11, 104-108.

Rubin K. H., van der Zander I., Smith M. C., and Bergmanis E. C. (2005) Minimum speed limit for ocean ridge magmatism from ${ }^{210} \mathrm{~Pb}_{-}{ }^{226} \mathrm{Ra}^{-230} \mathrm{Th}$ disequilibria. Nature 437, 534-538.

Rudge J. F., Maclennan J., and Stracke A. (2013) The geochemical consequences of mixing melts from a heterogeneous mantle. Geochim. Cosmochim. Acta 114, 112-143.

Salters, V. J. M., Blichert-Toft J., Fekiacova Z., Sachi-Kocher A., and Bizimis M. (2006) Isotope and trace element evidence for depleted lithosphere in the source of enriched Ko'olau basalts. Contrib. Mineral. Petrol. 151, 297-312.

Salters V. J. M. and Hart S. R. (1989) The Hf-paradox, and the role of garnet in the MORB source. Nature 342, 420-422.

Salters V. J. M. and Longhi J. (1999) Trace element partitioning during the initial stages of melting beneath mid-ocean ridges. Earth Planet. Sci. Lett. 166, 15-30.

Salters V. J. M., Longhi J. E. and Bizimis M. (2002) Near mantle solidus trace element partitioning at pressures up to 3.4 GPa. Geochem. Geophys. Geosyst. 3.

Salters V. J. M. and Sachi-Kocher A. (2010) An ancient metasomatic source for the Walvis Ridge basalts. Chem. Geol. 273, 151-167.

Salters V. J. M. and Stracke A. (2004) Composition of the depleted mantle. Geochem. Geophys. Geosyst. 5.

Salters V. J. M. and White W. M. (1998) Hf isotope constraints on mantle evolution. Chem. Geol. 145, 447-460.

Sherrod D. R., Hagstrum J. T., McGeehin J. P., Champion D. E. and Trusdell F. A. (2006) Distribution, ${ }^{14}$ C chronology, and paleomagnetism of latest Pleistocene and Holocene lava flows at Haleakalā volcano, Island of Maui, Hawai'i: A revision of lava flow hazard zones. J. Geophys. Res. 111.

Sherrod D. R. and McGeehin J. P. (1999) New Radiocarbon ages from Haleakala Crater, Island of Maui, Hawaii. USGS Open-File Report 99-143.

Sherrod D. R., Nishimitsu Y. and Tagami T. (2003) New K-Ar ages and the geologic evidence against rejuvenated-stage volcanism at Haleakalā, East Maui, a postshield-stage volcano of the Hawaiian island chain. Geol. Soc. Am. Bull. 115, 683-694.

Sims K. W. W., Blichert-Toft J., Kyle P. R., Pichat S., Gauthier P., Blusztajn J., Kelly P., Ball L. and Layne G. (2008a) A Sr, Nd, Hf, and Pb isotope perspective on the genesis and long-term evolution of alkaline magmas from Erebus volcano, Antarctica. J. Volcanol. Geoth. Res. 177, 606-618.

Sims K. W. W., DePaolo D. J., Murrell M. T., Baldridge W. S., Goldstein S. J. and Clague D. A. (1995) Mechanisms of Magma Generation Beneath Hawaii and Mid-Ocean Ridges: Uranium/Thorium and Samarium/Neodymium Isotopic Evidence. Science 267, 508-512.

Sims K. W. W., DePaolo D. J., Murrell M. T., Baldridge W. S., Goldstein S., Clague D. and Jull M. (1999) Porosity of the melting zone and variations in the solid mantle upwelling rate beneath Hawaii: inferences from ${ }^{238} \mathrm{U}_{-}^{230} \mathrm{Th}_{-}{ }^{226} \mathrm{Ra}$ and ${ }^{235} \mathrm{U}_{-}^{231} \mathrm{~Pa}$ disequilibria. Geochim. Cosmochim. Acta 63, 4119 4138, doi: 10.1016/S0016-7037(99)00313-0.

Sims K. W. W., Gill J. B., Dossetto A., Hoffmann D. L., Lundstrom C. C., Williams R. W., Ball L., Tollstrup D., Turner S., Prytulak J., Glessner J. J. G., Standish J. J., and Elliott T. (2008b) An inter- 
laboratory assessment of the Th Isotopic Composition of Synthetic and Rock standards. Geostand. Geoanal. Res. 32, 65-91. doi: 10.1111/j.1751-908X.2008.00870.x.

Sims K. W. W., Goldstein S. J., Blichert-Toft J., Perfit M. R., Kelemen P., Fornari D. J., Michael P., Murrell M. T., Hart S. R., DePaolo D. J., Layne G., Ball L., Jull M., and Bender P. (2002) Chemical and isotopic constraints on the generation and transport of magma beneath the East Pacific Rise. Geochim. Cosmochim. Acta 66, 3481-3504.

Sims K. W. W. and Hart S. R. (2006) Comparison of Th, Sr, Nd and Pb isotopes in oceanic basalts: Implications for mantle heterogeneity and magma genesis. Earth Planet. Sci. Lett. 245, 743-761.

Sims K. W. W., Hart S. R., Reagan M. K., Blusztajn J., Staudigel H., Sohn R. A., Layne G. D., Ball L. A., and Andrews J. (2008c) ${ }^{238} \mathrm{U}_{-}{ }^{230} \mathrm{Th}_{-}{ }^{226} \mathrm{Ra}_{-}{ }^{210} \mathrm{~Pb}^{-210} \mathrm{Po}^{232} \mathrm{Th}^{228}{ }^{228}$ and ${ }^{235} \mathrm{U}_{-}{ }^{231} \mathrm{~Pa}$ constraints on the ages and petrogenesis of Vailulu and Malumalu Lavas, Samoa. Geochem. Geophys. Geosyst. 9.

Sims, K. W. W., Maclennan J., Blichert-Toft J., Mervine, E. M., Blusztajn J., and Grönvold K. (2013) Short length scale mantle heterogeneity beneath Iceland probed by glacial modulation of melting. Earth Planet. Sci. Lett. 379, 146-157.

Sleep N. H. (1990) Hotspots and Mantle Plumes: Some Phenomenology. J. Geophys. Res. 95, 6715-6736.

Sobolev A. V., Hofmann A. W., Sobolev S. V. and Nikogosian I. K. (2005) An olivine-free mantle source of Hawaiian shield basalts. Nature 434, 590-597.

Spiegelman M. (2000) UserCalc: a web-based Uranium series calculator for magma-migration problems.

Spiegelman M. and Elliott T. (1993) Consequences of melt transport for uranium series disequilibrium in young lavas. Earth Planet. Sci. Lett. 118, 1-20.

Stearns H. T. (1940) Four-phase volcanism in Hawaii. Geol. Soc. Am. Bull. 51, 1947-1948.

Stearns H. T. and Macdonald G. A. (1942) Geology and ground-water resources of the island of Maui, Hawaii (including Haleakala section, Hawaii National Park). Advertiser Pub. Co., Honolulu.

Stracke A. and Bourdon B. (2009) The importance of melt extraction for tracing mantle heterogeneity. Geochim. Cosmochim. Acta 73, 218-238.

Stracke A., Bourdon B., and McKenzie D. (2006) Melt extraction in the Earth's mantle: Constraints from U-Th-Pa-Ra studies in oceanic basalts. Earth Planet. Sci. Lett. 244, 97-112.

Stracke A., Salters V. J. M. and Sims K. W. W. (1999) Assessing the presence of garnet-pyroxenite in the mantle sources of basalts through combined hafnium-neodymium-thorium isotope systematics. Geochem. Geophys. Geosyst. 1, 1-13.

Tanaka R., Makishima A., and Nakamura E. (2008) Hawaiian double volcanic chain triggered by an episodic involvement of recycled material: Constraints from temporal $\mathrm{Sr}-\mathrm{Nd}-\mathrm{Hf}-\mathrm{Pb}$ isotopic trend of the Loa-type volcanoes. Earth Planet. Sci. Lett. 265, 450-465.

Tanaka R., Nakamura E., and Takahashi E. (2002) Geochemical Evolution of Koolau Volcano, Hawaii. In: Hawaiian Volcanoes: Deep Underwater Perspectives; Geophysical Monograph 128, 311-332.

Taras B. D. and Hart S. R. (1987) Geochemical evolution of the New England seamount chain: Isotopic and trace-element constraints. Chem. Geol. 64, 35-54.

Todt W., Cliff R. A., Hanser A., and Hofmann A.W. (1996) Evaluation of a ${ }^{202} \mathrm{~Pb}^{2}{ }^{205} \mathrm{~Pb}$ double spike for high-precision lead isotope analysis. In: Earth processes, reading the isotopic code, 95 (eds. S. R. Hart and A. Basu) AGU, 429-437.

Tuli D. (2000) Nuclear wallet cards, 114 p. Brookhaven Natl. Lab., Upton, N.Y.

van Westrenen W., Blundy J., and Wood B. (1999) Crystal-chemical controls on trace element partitioning between garnet and anhydrous silicate melt. Am. Min. 84, 838-847.

Wagner T. P. and Grove T. L. (1998) Melt/harzburgite reaction in the petrogenesis of tholeiitic magma from Kilauea volcano, Hawaii. Contrib. Mineral. Petrol. 131, 1-12.

Wang Z. and Gaetani G. A. (2008) Partitioning of Ni between olivine and siliceous eclogite partial melt: experimental constraints on the mantle source of Hawaiian basalts. Contrib. Mineral. Petrol. 156, 661-678.

Waters C. L., Sims K. W. W., Perfit M. R., Blichert-Toft J., and Blusztajn J. (2011) Perspective on the Genesis of E-MORB from Chemical and Isotopic Heterogeneity at $9-10^{\circ} \mathrm{N}$ East Pacific Rise. $J$. Petrol. 52, 565-602.

Watson S. and McKenzie D. (1991) Melt Generation by Plumes - A Study of Hawaiian Volcanism. $J$. Petrol. 32, 501-537.

Wendt J. I., Regelous M., Niu Y., Hékinian R., and Collerson K. D. (1999) Geochemistry of lavas from the Garrett Transform Fault: insights into mantle heterogeneity beneath the eastern Pacific. Earth Planet. Sci. Lett. 173, 271-284. 
Weis D., Garcia M. O., Rhodes J. M., Jellinek M. and Scoates J. S. (2011) Role of the deep mantle in generating the compositional asymmetry of the Hawaiian mantle plume. Nature Geosci. 4, 831-838.

West H. B. and Leeman W. P. (1987) Isotopic evolution of lavas from Haleakala Crater, Hawaii. Earth Planet. Sci. Lett. 84, 211-225.

Weatherly S. M. and Katz R. F. (2016) Melt transport rates in heterogeneous mantle beneath mid-ocean ridges. Geochim. Cosmochim. Acta 172, 39-54.

White, W. M., Albarède F., and Telouk P. (2000) High-precision analysis of $\mathrm{Pb}$ isotope ratios by multicollector ICP-MS. Chem. Geol. 167, 257-270.

Wilson J. T., (1963) A possible origin of the Hawaiian Islands. Can. J. Phys. 41, 863-870.

Wolfe C. J., Solomon S. C., Laske G., Collins J. A., Detrick R. S., Orcutt J. A., Bercovici D. and Hauri E. H. (2011) Mantle P-wave velocity structure beneath the Hawaiian hotspot. Earth Planet. Sci. Lett. 303, 267-280.

Workman R. K., Hart S. R., Jackson M., Regelous M., Farley K. A., Blusztajn J., Kurz M. and Staudigel H. (2004) Recycled metasomatized lithosphere as the origin of the Enriched Mantle II (EM2) endmember: Evidence from the Samoan Volcanic Chain. Geochem. Geophys. Geosyst. 5.

Xu G., Frey F. F., Clague D. A., Weis D., and Beeson M. H. (2005) East Molokai and other Kea-trend volcanoes: Magmatic processes and sources as they migrate away from the Hawaiian hot spot. Geochem. Geophys. Geosyst. 6.

Yogodzinski G. M., Brown S. T., Kelemen P. B., Vervoort J. D., Portnyagin M., Sims K. W. W., Hoernle K., Jicha B. R. and Werner R. (2015) The Role of Subducted Basalt in the Source of Island Arc Magmas: Evidence from Seafloor Lavas of the Western Aleutians. J. Petrol. 0, 1-52.

Zhao D., Yamamoto Y. and Yanada T. (2013) Global mantle heterogeneity and its influence on teleseismic regional tomography. Gondwana Res. 23, 595-616.

Zindler A. and Hart S. R. (1986) Chemical geodynamics. Annu. Rev. Earth Planet. Sci. 14, 493-571.

\section{$\underline{\text { Figure Captions }}$}

Figure 1: Map of Maui (top) highlighting the Hana Volcanics and map of Haleakala

Crater (bottom) with locations of the 13 new samples presented in this paper, marked with purple stars. Ages for samples dated by ${ }^{14} \mathrm{C}$ are shown (Sherrod and McGeehin, 1999). Kea and Loa trends on general location map from Weis et al. (2011).

Figure 2: Total alkalis vs. silica diagram comparing Haleakala lavas to averages for other Hawaiian volcanoes. Measured $\mathrm{SiO}_{2}$ content is plotted and is not corrected for olivine fractionation because samples were picked free of phenocrysts prior to analysis. Haleakala Crater basanites from this study are shown as red diamonds and SWRZ samples (Sims et al., 1999) as red squares. Literature data for the Kula and Hana Volcanics are grouped together and include Hana lavas designated as either postshield or rejuvenated stage in the original work. The GEOROC database was used to compile comparison data for this figure and subsequent figures. Entries in the GEOROC database that come from references older than 1980, are not volcanic rocks, or are denoted as altered were not included in any comparison data. See supplement for full list of 
references used in comparison data. In Figure 2, averages for various stages of Hawaiian

1100 volcanoes include data entries for which an eruptive stage (e.g., postshield) is designated

1101 in the GEOROC database. Hualalai averages do not include trachyte lavas. L.D. denotes

1102 literature data.

1103

1104 Figure 3: Trace element diagram comparing the Hana Volcanics with averages for other

1105 Hawaiian volcanoes and Pacific MORB. Averages for Kilauea, Mauna Loa, Mauna Kea,

1106 Hualalai, and Loihi include data from all eruptive stages. Hualalai trachytes are excluded

1107 from average. Element concentrations normalized to primitive mantle values of

1108 McDonough and Sun (1995). See supplement for full list of references used in

1109 comparison data. L.D. denotes literature data.

1110

1111 Figure $4:{ }^{87} \mathrm{Sr} /{ }^{86} \mathrm{Sr}$ versus $\varepsilon_{\mathrm{Nd}}$ showing the depleted isotopic signature of Haleakala Crater,

1112 SWRZ and other postshield lavas compared to other Hawaiian volcanoes. Literature data

1113 for the Kula and Hana Volcanics are grouped together and include Hana lavas designated

1114 as either postshield or rejuvenated stage in the original work; this group is distinguished

1115 from literature data for the shield-stage Honomanu Basalt, which is $>0.93 \mathrm{Ma}$. Inset

1116 displays the range in Hawaiian data compared to OIB and Pacific MORB. Mantle end

1117 member compositions from the following sources: DMM (Salters and Stracke, 2004;

1118 extreme D-MORB); HIMU and EM1 (Hart et al., 1992; Zindler and Hart, 1986); EM2

1119 (Workman et al., 2004). See supplement for full list of references used in comparison

1120 data. L.D. denotes literature data.

1121

1122 Figure 5: $\varepsilon_{\mathrm{Nd}}$ versus $\varepsilon_{\mathrm{Hf}}$ showing the depleted isotopic signature of Haleakala Crater,

1123 SWRZ and other postshield lavas compared to other Hawaiian volcanoes. For SWRZ

1124 samples, Nd isotopic data reported in Sims et al. (1999) and Hf isotopic data reported in

1125 Stracke et al. (1999). Literature data for the Kula and Hana Volcanics are grouped

1126 together and include Hana lavas designated as either postshield or rejuvenated stage in

1127 the original work; this group is distinguished from literature data for the shield-stage

1128 Honomanu Basalt, which is $>0.93 \mathrm{Ma}$. Inset displays the range in Hawaiian data

1129 compared to OIB and Pacific MORB. Mantle end member composition for DMM from 
1130 Salters and Stracke (2004; extreme D-MORB). Neodymium isotopic composition for

1131 HIMU and EM1 from Hart et al. (1992) and Zindler and Hart (1986) and EM2 from

1132 Workman et al. (2004). Hafnium isotopic composition for HIMU, EM1 and EM2 from

1133 Salters and White (1998). See supplement for full list of references used in comparison

1134 data. L.D. denotes literature data.

1135

1136 Figure 6: (a.) ${ }^{206} \mathrm{~Pb} /{ }^{204} \mathrm{~Pb}$ vs. ${ }^{208} \mathrm{~Pb} /{ }^{204} \mathrm{~Pb}$ and (b.) ${ }^{206} \mathrm{~Pb} /{ }^{204} \mathrm{~Pb}$ vs. ${ }^{87} \mathrm{Sr} /{ }^{86} \mathrm{Sr}$ comparing

1137 Haleakala Crater, SWRZ, and other postshield lavas to other Hawaiian volcanoes. For

1138 SWRZ samples Sr isotopic data reported in Sims et al. (1999) and Pb isotopic data

1139 reported in Table 3. Literature data for the Kula and Hana Volcanics are grouped together

1140 and include Hana lavas designated as either postshield or rejuvenated stage in the original

1141 work; this group is distinguished from literature data for the shield-stage Honomanu

1142 Basalt, which is $>0.93$ Ma. Black line in (a.) is from Abouchami et al. (2005) and Weis et

1143 al. (2011) and divides Loa trend volcanoes (Mauna Loa, Hualalai, and Loihi) from Kea

1144 trend volcanoes (Mauna Kea, Kilauea, and Haleakala). Pink lines in (b.) outline the

1145 ranges of Pacific MORB data for the Garrett Transform from Wendt et al. (1999) and

1146 axial East Pacific Rise (EPR) samples from 950’N and 9³0’ N from Sims et al. (2002).

1147 Lead isotope comparison data from the literature include measurements made by MC-

1148 ICP-MS, double-spike TIMS, and conventional TIMS. See supplement for full list of

1149 references used in comparison data. L.D. denotes literature data.

1150

1151 Figure 7: Ce/Sm (normalized to primitive mantle values of McDonough and Sun, 1995)

1152 vs. ${ }^{87} \mathrm{Sr} /{ }^{86} \mathrm{Sr}, \varepsilon_{\mathrm{Nd}}$, and ${ }^{208} \mathrm{~Pb} /{ }^{206} \mathrm{~Pb}$. Haleakala Crater data from this study, Haleakala

1153 SWRZ from Sims et al. (1999), and other Haleakala data from the Kula and Hana

1154 Volcanics from multiple literature sources (see supplement). Literature data for the Kula

1155 and Hana Volcanics are grouped together and include Hana lavas designated as either

1156 postshield or rejuvenated stage in the original work. We assume Kilauea tholeiites most

1157 closely represent the most recent eruptive products from the center of the Hawaiian

1158 plume (Bryce et al., 2005; DePaolo and Stolper, 1996). Squares are averages for

1159 Haleakala postshield lavas (red), Kilauea (green), and Pacific MORB (gray). Triangles

1160 are calculated initial solid source values. For this calculation we use a batch melting 
1161 equation and melt fractions of 3\% for Haleakala postshield lavas, $15 \%$ for Kilauea

1162 lavas, and 20\% for Pacific MORB lavas. These melt fractions are based on modeled melt

1163 fractions for Hawaiian lavas by Sims et al. (1999) and the maximum amount of mantle

1164 melting predicted at ocean ridges by Klein and Langmuir (1987). Bulk distribution

1165 coefficients for garnet peridotite (59\% olivine, $21 \%$ opx, $8 \% \mathrm{cpx}, 12 \%$ garnet) are 0.0065

1166 for $\mathrm{Ce}$ and 0.0474 for $\mathrm{Sm}$. We plot the $\mathrm{Ce} / \mathrm{Sm}$ ratios in order to utilize self-consistent

1167 partition coefficients from Salters and Longhi (1999) and Salters et al. (2002), who do not

1168 report La partitioning data; an average of the partition coefficients of all experiments at

1169 pressures $>2.4 \mathrm{GPa}$ from both publications were used for cpx, opx, and garnet; the

1170 partition coefficient for olivine from the $1 \mathrm{GPa}$ experiment was used because higher

1171 pressure experimental data was not given. Utilization of different partition coefficients

1172 (e.g., Adam and Green, 2006 for basanites) shifts the initial solid values slightly to the

1173 left or right on this plot, but does not affect the interpretation of the model. Also shown

1174 are the isotopic values of the Depleted Rejuvenated Component (DRC) of Bizimis et al.

1175 (2013) in blue $\left({ }^{87} \mathrm{Sr} /{ }^{86} \mathrm{Sr}\right.$ for the DRC is defined as $\left.<0.70305\right)$ and the isotopic values of

1176 the Depleted Makapuu component (DMK) of Tanaka et al. (2008) in orange. Based on Sr

1177 and Nd isotopic data the Haleakala solid mantle source could be a two-component mix of

1178 the Pacific MORB and plume (Kilauea) initial solids. The Pb isotope data, however,

1179 suggest that this is not the case and that the Haleakala initial solid is likely a mixture of

1180 plume material and a high ${ }^{208} \mathrm{~Pb} /{ }^{206} \mathrm{~Pb}$ component, possibly an extreme Pacific MORB

1181 composition, the DRC of Bizimis et al. (2013), or the DMK component of Tanaka et al.

1182 (2008). Lead isotope comparison data from the literature include measurements made by

1183 MC-ICP-MS, double-spike TIMS, and conventional TIMS. See supplement for full list of

1184 references used in comparison data. L.D. denotes literature data.

1185

1186 Figure 8: $\varepsilon_{\mathrm{Nd}}$ versus Ba/Ta for Haleakala Crater, SWRZ and other postshield lavas

1187 compared to other Hawaiian volcanoes. For SWRZ samples, Nd isotopic data reported in

1188 Sims et al. (1999). Literature data for the Kula and Hana Volcanics are grouped together

1189 and include Hana lavas designated as either postshield or rejuvenated stage in the original

1190 work; this group is distinguished from literature data for the shield-stage Honomanu 
1191 Basalt, which is $>0.93 \mathrm{Ma}$. See supplement for full list of references used in comparison

1192 data. L.D. denotes literature data.

1194 Figure 9: $\left({ }^{230} \mathrm{Th} /{ }^{238} \mathrm{U}\right)$ vs. $\left({ }^{231} \mathrm{~Pa} /{ }^{235} \mathrm{U}\right)$ (top) and $\left({ }^{230} \mathrm{Th} /{ }^{238} \mathrm{U}\right)$ vs. $\left({ }^{226} \mathrm{Ra} /{ }^{230} \mathrm{Th}\right)$ (bottom) for 1195 Hawaiian lavas. Pickett and Murrell (1997) report $\left({ }^{231} \mathrm{~Pa} /{ }^{235} \mathrm{U}\right)$ for select Hawaiian 1196 samples for which other U-series data are reported in Sims et al. (1999). ${ }^{230} \mathrm{Th} /{ }^{238} \mathrm{U}$ ) and $\left.1197{ }^{226} \mathrm{Ra} /{ }^{230} \mathrm{Th}\right)$ data for one whole rock sample from Cooper et al. (2001) is included in 1198 comparison data. Grid lines represent dynamic melting models (after McKenzie, 1985) 1199 and show that melting rates for Haleakala basanites are between approximately $1 \times 10^{-5}$ 1200 and $1 \times 10^{-4} \mathrm{~kg} \mathrm{~m}^{-3} \mathrm{yr}^{-1}$ with melt-zone porosity from $0.2 \%$ to $0.5 \%$, significantly lower 1201 than shield-stage tholeiites.

1203 Figure 10: Chromatographic porous flow modeling using the web-based UserCalc 1204 program of Spiegelman (2000) for Kilauea and Mauna Loa tholeiites (a), Hualalai alkali 1205 basalts (b), and Haleakala basanites (c). This program is based on the chromatographic 1206 models of Spiegelman and Elliott (1993). The contour plots model the solid mantle 1207 upwelling velocity and porosity of the melt zone using three $\mathrm{U}$-series nuclide pairs (red 1208 for $\left({ }^{230} \mathrm{Th} /{ }^{238} \mathrm{U}\right)$; green for $\left({ }^{226} \mathrm{Ra} /{ }^{230} \mathrm{Th}\right)$; blue for $\left.\left({ }^{231} \mathrm{~Pa} /{ }^{235} \mathrm{U}\right)\right)$. The point at which the 1209 three lines coincide is the modeled porosity and solid mantle upwelling velocity. Average 1210 disequilibria values for tholeiites are shown in the left plot and include data from Cohen 1211 and O'Nions (1993), Cohen et al. (1996), Cooper et al. (2001; whole rock data), Pickett 1212 and Murrell, (1997), Pietruszka et al. (2001; 2006), and Sims et al. (1999). Average 1213 disequilibria values for Hualalai alkali basalts from Pickett and Murrell (1997) and Sims 1214 et al. (1999) are shown in the middle plot. Average disequilibria values for Haleakala 1215 basanites are shown in the right plot and include new Haleakala Crater lavas and 1216 Haleakala SWRZ lavas (Pickett and Murrell, 1997; Sims et al., 1995; 1999). Models were 1217 produced using inverted $\mathrm{D}$ values for $\mathrm{U}$ and $\mathrm{Th}$ for garnet peridotite source of Sims et al. 1218 (1999) and for Ra and Pa from Lundstrom et al. (1994). Error envelopes (dashed) signify 12191 standard deviation of the mean values. The upper error bound for $\left({ }^{230} \mathrm{Th} /{ }^{238} \mathrm{U}\right)$ for the 1220 tholeiites is outside the plotted area (a). 
1222 Figure 11: Alpha Sm/Nd vs. $\left({ }^{230} \mathrm{Th} /{ }^{238} \mathrm{U}\right)$ for Hawaiian volcanoes. Alpha $\mathrm{Sm} / \mathrm{Nd}$

1223 represents $\mathrm{Sm} / \mathrm{Nd}$ fractionation and is defined as $(\mathrm{Sm} / \mathrm{Nd})_{\mathrm{magma}} /(\mathrm{Sm} / \mathrm{Nd})_{\text {source. }}$. Batch

1224 melting and accumulation fractional melting models for a garnet lherzolite source (12\%

1225 garnet, $8 \% \mathrm{cpx}, 21 \% \mathrm{opx}, 59 \%$ olivine) utilize the following $\mathrm{D}$ values: $\mathrm{D}_{\mathrm{Sm}}=0.04 ; \mathrm{D}_{\mathrm{Nd}}=$

$12260.02 ; \mathrm{D}_{\mathrm{Th}}=0.0026 ; \mathrm{D}_{\mathrm{U}}=0.0052$ (McKay, 1989; Salters and Longhi, 1999; Salters et al.,

1227 2002). Alpha Sm/Nd for Kilauea calculated from data in Garcia et al. (1996; 2000)

1228 Marske et al. (2008), and Pietruszka et al. (2006). Alpha Sm/Nd for Loihi calculated from

1229 data in Garcia et al. $(1993 ; 1998)$ and Pietruszka et al. $\left(2011\right.$; corrected $\left({ }^{230} \mathrm{Th} /{ }^{238} \mathrm{U}\right)$

1230 values).

1231

1232 Figure 12: $\left({ }^{230} \mathrm{Th} /{ }^{238} \mathrm{U}\right),\left({ }^{226} \mathrm{Ra} /{ }^{230} \mathrm{Th}\right)$, and $\left({ }^{231} \mathrm{~Pa} /{ }^{235} \mathrm{U}\right)$ versus $\mathrm{SiO}_{2}, \mathrm{La} / \mathrm{Sm}, \mathrm{Ba} / \mathrm{Ta}$, and

$1233 \varepsilon_{\mathrm{Nd}}$ for Haleakala and other Hawaiian volcanoes. L.D. denotes literature data and includes

1234 data from the following sources: Cohen and O’Nions (1993), Cohen et al. (1996), Garcia

1235 et al. (1992; 1993; 1996; 1998; 2000; 2003), Marske et al. (2008), Pickett and Murrell

1236 (1997), Pietruszka and Garcia (1999), Pietruszka et al. (2001; 2006; 2011), Sims et al.

1237 (1999). Measured $\mathrm{SiO}_{2}$ content is plotted and is not corrected for olivine fractionation

1238 because samples were picked free of phenocrysts prior to analysis. 
Table 1: Locations and ages of Haleakala Crater basanite samples.

\begin{tabular}{|c|c|c|c|c|c|}
\hline & Source or flow name & Latitude, $\mathrm{N}$ & Longitude, $\mathrm{W}$ & Age, in ${ }^{14} \mathrm{C}$ yr B.P. & Reference \\
\hline HK-16 & Sliding Sands lava & $20^{\circ} 42.483^{\prime}$ & $156^{\circ} 12.749^{\prime}$ & $1000-2000$ & 2 \\
\hline HK-17 & $\mathrm{Pu}^{\prime} \mathrm{u}$ o Pele lava & $20^{\circ} 42.594^{\prime}$ & $156^{\circ} 12.745^{\prime}$ & $\sim 4000$ & 2 \\
\hline HK-18 & Ka Lu'u o ka 'O'o lava & $20^{\circ} 42.597^{\prime}$ & $156^{\circ} 12.649^{\prime}$ & $<970 ; 800-950$ & 2 \\
\hline HK-19 & $\mathrm{Pu}^{\varsigma} \mathrm{u}$ Maile lava & $20^{\circ} 42.455^{\prime}$ & $156^{\circ} 10.435^{\prime}$ & $4070 \pm 50$ & 1 \\
\hline HK-21 & Pu'u Nole lava & $20^{\circ} 42.814^{\prime}$ & $156^{\circ} 10.568^{\prime}$ & $1160 \pm 50$ & 1 \\
\hline HK-22 & Kalua Awa lava & $20^{\circ} 43.464^{\prime}$ & $156^{\circ} 09.286^{\prime}$ & $1040 \pm 40$ & 1 \\
\hline HK-23 & Hanakauhi fissure & $20^{\circ} 43.790^{\prime}$ & $156^{\circ} 10.352^{\prime}$ & $870 \pm 40$ & 1 \\
\hline HK-25 & Aphyric spatter rampart & $20^{\circ} 43.823^{\prime}$ & $156^{\circ} 10.155^{\prime}$ & $1870 \pm 40$ & 1 \\
\hline HK-26 & Kalua Awa lava & $20^{\circ} 43.764^{\prime}$ & $156^{\circ} 10.083^{\prime}$ & $900-1040$ & 2 \\
\hline HK-28 & Halali`i lava & $20^{\circ} 43.342^{\prime}$ & $156^{\circ} 12.085^{\prime}$ & $<940$ & 2 \\
\hline HK-29 & Youngest $\mathrm{Ka} \mathrm{Lu}$ 'u o ka 'O'o lava & $20^{\circ} 43.812^{\prime}$ & $156^{\circ} 13.426^{\prime}$ & $<970$ & 2 \\
\hline HK-30 & Halali‘i lava & $20^{\circ} 44.455^{\prime}$ & $156^{\circ} 12.219^{\prime}$ & $940 \pm 50$ & 1 \\
\hline HK-31 & Ka Lu'u o ka 'O'o lava & $20^{\circ} 44.561^{\prime}$ & $156^{\circ} 13.053^{\prime}$ & $970 \pm 50$ & 1 \\
\hline
\end{tabular}

All samples collected by K. Sims and D. Sherrod, May 1999. Geographic coordinates referable to datum WGS84.

1: ${ }^{14} \mathrm{C}$ age from Sherrod and McGeehin, 1999

2: Age bracketed by stratigraphic relations with dated lava flows, extent of weathering and soil development,

and paleomagnetic directions in conjunction with paleosecular variation curve (Sherrod et al., 2006). 
Table 2: Major and trace element data for Haleakala Crater basanites.

\begin{tabular}{|c|c|c|c|c|c|c|c|c|c|c|c|c|c|c|c|c|c|}
\hline & HK-16 & HK-17 & HK-18 & HK-19 & HK-21 & HK-22 & $\begin{array}{c}\text { HK- } \\
23 \\
\end{array}$ & $\begin{array}{c}\text { HK- } \\
25 \\
\end{array}$ & $\begin{array}{c}\text { HK- } \\
26 \\
\end{array}$ & $\begin{array}{c}\text { HK- } \\
28 \\
\end{array}$ & $\begin{array}{c}\text { HK- } \\
29 \\
\end{array}$ & $\begin{array}{c}\text { HK- } \\
30 \\
\end{array}$ & $\begin{array}{c}\text { HK- } \\
31 \\
\end{array}$ & $\begin{array}{c}\text { BHVO- } \\
2 \\
\end{array}$ & $\begin{array}{c}\text { BHVO- } \\
2 \\
\end{array}$ & $\% \mathrm{RSD}$ & $\begin{array}{c}\text { BHVO-2 } \\
\text { recommended }\end{array}$ \\
\hline $\mathrm{SiO}_{2}$ (wt.\%) & 44.91 & 45.95 & 41.96 & 45.25 & 42.28 & 42.88 & 41.91 & 46.78 & 43.89 & 42.95 & 42.59 & 44.87 & 42.69 & 50.09 & 50.34 & $0.4 \%$ & $49.9 \pm 0.6$ \\
\hline $\mathrm{TiO}_{2}$ & 3.61 & 3.23 & 3.94 & 3.40 & 3.20 & 3.29 & 4.01 & 2.87 & 3.38 & 3.38 & 3.92 & 3.13 & 3.86 & 2.70 & 2.69 & $0.2 \%$ & $2.73 \pm 0.04$ \\
\hline $\mathrm{Al}_{2} \mathrm{O}_{3}$ & 16.64 & 16.38 & 14.03 & 16.49 & 12.39 & 12.65 & 14.75 & 17.59 & 12.90 & 13.05 & 13.79 & 15.55 & 13.86 & 13.56 & 13.54 & $0.1 \%$ & $13.5 \pm 0.2$ \\
\hline $\mathrm{Fe}_{2} \mathrm{O}_{3}$ & 14.45 & 14.05 & 15.88 & 13.88 & 15.88 & 15.11 & 16.06 & 12.24 & 15.17 & 15.20 & 15.78 & 13.65 & 15.55 & 12.41 & 12.35 & $0.3 \%$ & $12.3 \pm 0.2$ \\
\hline $\mathrm{MnO}$ & 0.20 & 0.20 & 0.21 & 0.20 & 0.19 & 0.19 & 0.22 & 0.22 & 0.19 & 0.19 & 0.21 & 0.21 & 0.21 & 0.16 & 0.16 & $0.0 \%$ & $0.13 \pm 0.004$ \\
\hline $\mathrm{MgO}$ & 5.46 & 5.94 & 6.90 & 5.08 & 10.61 & 9.34 & 6.01 & 3.65 & 8.77 & 9.49 & 6.83 & 6.01 & 6.88 & 7.27 & 7.27 & $0.0 \%$ & $7.23 \pm 0.12$ \\
\hline $\mathrm{CaO}$ & 8.99 & 9.93 & 11.29 & 8.59 & 11.94 & 11.95 & 10.12 & 7.73 & 11.98 & 11.97 & 11.15 & 9.43 & 11.24 & 11.38 & 11.32 & $0.4 \%$ & $11.4 \pm 0.2$ \\
\hline $\mathrm{Na}_{2} \mathrm{O}$ & 4.05 & 3.90 & 3.76 & 4.36 & 2.53 & 2.63 & 4.09 & 5.13 & 2.87 & 2.73 & 3.94 & 4.27 & 3.73 & 2.35 & 2.24 & $3.3 \%$ & $2.22 \pm 0.08$ \\
\hline $\mathrm{K}_{2} \mathrm{O}$ & 1.41 & 1.39 & 1.43 & 1.58 & 0.88 & 0.82 & 1.61 & 1.88 & 0.93 & 0.93 & 1.56 & 1.65 & 1.53 & 0.54 & 0.53 & $0.7 \%$ & $0.52 \pm 0.01$ \\
\hline $\mathrm{P}_{2} \mathrm{O}_{5}$ & 0.57 & 0.58 & 0.58 & 0.58 & 0.37 & 0.37 & 0.64 & 0.82 & 0.39 & 0.38 & 0.58 & 0.64 & 0.56 & 0.27 & 0.27 & $0.4 \%$ & $0.27 \pm 0.02$ \\
\hline Total & 100.29 & 101.54 & 100.00 & 99.42 & 100.27 & 99.23 & 99.41 & 98.90 & 100.48 & 100.28 & 100.35 & 99.40 & 100.12 & 100.73 & 100.72 & & \\
\hline $\mathrm{H}^{2} \mathrm{O}^{-}$ & 1.22 & 1.14 & 0.35 & 0.39 & 0.78 & 0.72 & 0.68 & 1.23 & 0.19 & 0.48 & 0.01 & 0.91 & 0.93 & & 0.776 & & \\
\hline LOI & 0.10 & 0.20 & -0.25 & -0.29 & -0.64 & -0.63 & -0.20 & 0.15 & -0.05 & -0.15 & -0.01 & -1.09 & -1.23 & & -0.460 & & \\
\hline Li (ppm) & 8.14 & 7.73 & 7.21 & 8.66 & 5.28 & 5.52 & 8.11 & 10.57 & 6.14 & 5.80 & 7.40 & 8.91 & 7.38 & 4.76 & 4.89 & $1.9 \%$ & 5 \\
\hline $\mathrm{Be}$ & 2.12 & 2.09 & 2.08 & 2.07 & 1.35 & 1.45 & 2.34 & 3.03 & 1.53 & 1.54 & 2.21 & 2.41 & 2.22 & 1.25 & 1.24 & $0.5 \%$ & \\
\hline $\mathrm{Sc}$ & 15.9 & 18.0 & 20.7 & 14.7 & 29.4 & 28.2 & 16.4 & 7.46 & 28.2 & 28.3 & 21.1 & 15.8 & 22.4 & 31.1 & 30.9 & $0.5 \%$ & $32 \pm 1$ \\
\hline $\mathrm{Ni}$ & 15.0 & 44.3 & 63.5 & 8.53 & 128 & 144 & 34.4 & 0.60 & 134 & 113 & 62.2 & 51.8 & 65.6 & 115 & 116 & $0.1 \%$ & $119 \pm 7$ \\
\hline $\mathrm{Cu}$ & 40.8 & 49.3 & 81.4 & 36.1 & 42.8 & 71.0 & 49.4 & 15.7 & 75.3 & 45.6 & 82.9 & 39.0 & 86.0 & 139 & 139 & $0.1 \%$ & $127 \pm 7$ \\
\hline Ga corr & 23.8 & 24.4 & 26.7 & 23.9 & 21.9 & 22.7 & 27.5 & 27.4 & 24.1 & 22.7 & 26.6 & 25.7 & 27.1 & 21.0 & 20.4 & $2.1 \%$ & $21.7 \pm 0.9$ \\
\hline $\mathrm{Cr}$ & 2.38 & 109 & 21.3 & 2.17 & 420 & 408 & 6.49 & 1.01 & 402 & 395 & 23.9 & 145 & 65.4 & 284 & 284 & $0.0 \%$ & $280 \pm 19$ \\
\hline Co & 39.2 & 39.8 & 51.8 & 35.5 & 61.4 & 57.5 & 49.7 & 23.6 & 55.2 & 54.9 & 52.9 & 40.7 & 53.1 & 44.8 & 44.1 & $1.2 \%$ & $45 \pm 3$ \\
\hline Y & 30.8 & 29.9 & 28.5 & 30.6 & 24.1 & 23.9 & 29.7 & 33.0 & 25.3 & 25.0 & 28.2 & 30.8 & 29.0 & 26.5 & 26.6 & $0.1 \%$ & $26 \pm 2$ \\
\hline $\mathrm{Zr}$ & 249 & 242 & 268 & 257 & 190 & 191 & 280 & 330 & 200 & 191 & 269 & 277 & 275 & 185 & 182 & $0.9 \%$ & $172 \pm 11$ \\
\hline V & 243 & 260 & 386 & 215 & 386 & 385 & 371 & 126 & 403 & 380 & 388 & 252 & 399 & 307 & 308 & $0.1 \%$ & $317 \pm 11$ \\
\hline $\mathrm{Nb}$ & 60.6 & 58.3 & 61.3 & 63.1 & 37.7 & 37.9 & 67.2 & 77.7 & 40.5 & 40.0 & 62.3 & 63.8 & 63.0 & 19.5 & 19.4 & $0.5 \%$ & $18 \pm 2$ \\
\hline Cs & 0.42 & 0.40 & 0.39 & 0.38 & 0.20 & 0.24 & 0.42 & 0.56 & 0.27 & 0.28 & 0.38 & 0.45 & 0.39 & 0.11 & 0.10 & $5.1 \%$ & \\
\hline $\mathrm{Zn}$ corr & 113 & 107 & 116 & 103 & 103 & 98.4 & 124 & 117 & 103 & 100 & 118 & 117 & 116 & 94.9 & 94.0 & $0.7 \%$ & $103 \pm 6$ \\
\hline $\mathrm{Ba}$ & 726 & 646 & 635 & 761 & 424 & 388 & 708 & 806 & 423 & 431 & 650 & 676 & 659 & 135 & 133 & $0.7 \%$ & $130 \pm 13$ \\
\hline $\mathrm{Rb}$ & 37.7 & 38.0 & 38.4 & 42.0 & 23.5 & 23.0 & 42.5 & 52.4 & 26.3 & 26.7 & 38.3 & 42.8 & 40.4 & 10.7 & 10.7 & $0.0 \%$ & $9.8 \pm 1.0$ \\
\hline $\mathrm{Sr}$ & 1005 & 912 & 902 & 1013 & 591 & 599 & 977 & 1059 & 629 & 610 & 905 & 933 & 920 & 397 & 395 & $0.4 \%$ & $389 \pm 23$ \\
\hline
\end{tabular}




\begin{tabular}{|c|c|c|c|c|c|c|c|c|c|c|c|c|c|c|c|c|c|}
\hline $\mathrm{Pb}$ & 2.99 & 2.55 & 2.57 & 2.95 & 1.47 & 1.51 & 2.76 & 2.49 & 1.59 & 1.49 & 2.58 & 2.75 & 2.60 & 1.63 & 1.61 & $1.1 \%$ & \\
\hline Th & 3.85 & 3.68 & 3.73 & 3.97 & 2.47 & 2.45 & 4.19 & 5.41 & 2.62 & 2.57 & 3.89 & 4.25 & 3.97 & 1.24 & 1.27 & $1.6 \%$ & $1.2 \pm 0.3$ \\
\hline $\mathrm{U}$ & 1.07 & 1.06 & 1.10 & 1.06 & 0.69 & 0.72 & 1.21 & 1.59 & 0.77 & 0.74 & 1.12 & 1.22 & 1.11 & 0.43 & 0.43 & $0.1 \%$ & \\
\hline $\mathrm{La}$ & 36.4 & 35.3 & 37.8 & 37.4 & 24.5 & 23.7 & 40.5 & 49.2 & 25.4 & 24.9 & 37.6 & 39.8 & 38.2 & 14.6 & 14.7 & $0.8 \%$ & $15 \pm 1$ \\
\hline $\mathrm{Ce}$ & 78.8 & 77.1 & 83.1 & 80.5 & 55.0 & 54.1 & 88.0 & 105 & 57.9 & 56.5 & 83.4 & 86.5 & 85.4 & 37.4 & 37.8 & $0.7 \%$ & $38 \pm 2$ \\
\hline $\operatorname{Pr}$ & 10.1 & 9.84 & 10.7 & 10.2 & 7.28 & 7.19 & 11.3 & 13.0 & 7.68 & 7.42 & 10.8 & 11.1 & 11.0 & 5.40 & 5.45 & $0.6 \%$ & \\
\hline $\mathrm{Nd}$ & 41.9 & 40.7 & 44.7 & 42.0 & 31.3 & 31.2 & 47.2 & 52.5 & 33.2 & 31.8 & 44.7 & 44.8 & 45.4 & 24.8 & 24.9 & $0.3 \%$ & $25.0 \pm 1.8$ \\
\hline Sm & 8.98 & 8.68 & 9.50 & 8.90 & 7.10 & 7.15 & 10.1 & 10.7 & 7.57 & 7.29 & 9.65 & 9.51 & 9.84 & 6.13 & 6.09 & $0.4 \%$ & $6.2 \pm 0.4$ \\
\hline $\mathrm{Eu}$ & 3.05 & 2.90 & 3.12 & 3.02 & 2.36 & 2.38 & 3.30 & 3.49 & 2.52 & 2.43 & 3.18 & 3.17 & 3.26 & 2.04 & 2.05 & $0.2 \%$ & \\
\hline Gd & 8.51 & 8.19 & 8.85 & 8.43 & 6.88 & 6.91 & 9.20 & 9.65 & 7.29 & 7.13 & 8.89 & 8.88 & 9.15 & 6.29 & 6.36 & $0.8 \%$ & $6.3 \pm 0.2$ \\
\hline $\mathrm{Tb}$ & 1.28 & 1.23 & 1.30 & 1.27 & 1.04 & 1.04 & 1.36 & 1.43 & 1.09 & 1.07 & 1.33 & 1.34 & 1.36 & 1.00 & 1.00 & $0.1 \%$ & 0.9 \\
\hline Dy & 6.55 & 6.29 & 6.38 & 6.47 & 5.30 & 5.33 & 6.70 & 7.14 & 5.59 & 5.51 & 6.46 & 6.65 & 6.60 & 5.40 & 5.46 & $0.9 \%$ & \\
\hline Но & 1.19 & 1.14 & 1.11 & 1.18 & 0.95 & 0.94 & 1.18 & 1.28 & 0.99 & 0.98 & 1.12 & 1.20 & 1.15 & 1.01 & 1.03 & $1.0 \%$ & $1.04 \pm 0.04$ \\
\hline $\mathrm{Er}$ & 2.96 & 2.82 & 2.64 & 2.94 & 2.28 & 2.27 & 2.82 & 3.17 & 2.40 & 2.37 & 2.67 & 2.98 & 2.77 & 2.53 & 2.55 & $0.4 \%$ & \\
\hline $\mathrm{Yb}$ & 2.34 & 2.23 & 1.92 & 2.36 & 1.72 & 1.71 & 2.08 & 2.49 & 1.79 & 1.79 & 1.93 & 2.26 & 1.98 & 2.07 & 2.04 & $0.9 \%$ & $2.0 \pm 0.2$ \\
\hline $\mathrm{Lu}$ & 0.34 & 0.32 & 0.27 & 0.34 & 0.25 & 0.24 & 0.30 & 0.36 & 0.26 & 0.26 & 0.27 & 0.33 & 0.28 & 0.30 & 0.29 & $0.5 \%$ & $0.28 \pm 0.01$ \\
\hline $\mathrm{Hf}$ & 6.07 & 5.83 & 6.55 & 6.13 & 5.01 & 5.10 & 6.88 & 7.37 & 5.34 & 5.04 & 6.72 & 6.48 & 6.82 & 4.69 & 4.78 & $1.3 \%$ & $4.1 \pm 0.3$ \\
\hline $\mathrm{Ta}$ & 3.68 & 3.49 & 3.75 & 3.80 & 2.31 & 2.40 & 4.14 & 4.76 & 2.56 & 2.49 & 3.85 & 3.88 & 3.91 & 1.28 & 1.28 & $0.2 \%$ & 1.4 \\
\hline
\end{tabular}

Major elements analyzed by ICP-OES at Boston University. Trace elements analyzed by VG PQ ExCell quadrupole ICP-MS at Boston University following the procedures of Kelley et al. (2003).

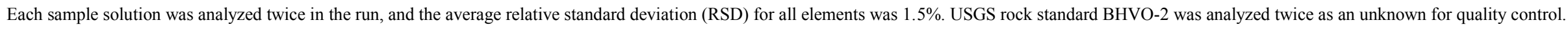
The inter-run precision can be assessed from the difference in BHVO-2 in the two runs and is generally better than 2\% relative standard deviation (RSD).

This precision is typical of that obtained in comparable analyses over several years in the Boston University lab. USGS recommended values of BHVO-2 are shown for comparison. 
Table 3: $\mathrm{Sr}, \mathrm{Nd}, \mathrm{Hf}$, and $\mathrm{Pb}$ isotopic data for Hana Volcanics samples.

\begin{tabular}{|c|c|c|c|c|c|c|c|c|}
\hline & ${ }^{87} \mathrm{Sr} /{ }^{86} \mathrm{Sr}^{\mathrm{a}, \mathrm{g}}$ & ${ }^{143} \mathrm{Nd} /{ }^{144} \mathrm{Nd} d^{b, g}$ & $\varepsilon_{\mathrm{Nd}}^{\mathrm{c}}$ & ${ }^{176} \mathrm{Hf} /{ }^{177} \mathrm{Hf}^{\mathrm{d}}$ & $\varepsilon_{\mathrm{Hf}}^{\mathrm{e}}$ & ${ }^{206} \mathrm{~Pb} /{ }^{204} \mathrm{~Pb}^{\mathrm{f}, \mathrm{g}}$ & ${ }^{207} \mathrm{~Pb} /{ }^{204} \mathrm{~Pb}^{\mathrm{f}, \mathrm{g}}$ & ${ }^{208} \mathrm{~Pb} /{ }^{204} \mathrm{~Pb}^{\mathrm{f}, \mathrm{g}}$ \\
\hline \multicolumn{9}{|c|}{ Haleakala Crater: } \\
\hline HK-16 & 0.703291 & 0.513019 & 7.4 & 0.283130 & 12.7 & 18.299 & 15.464 & 37.889 \\
\hline HK-17 & 0.703298 & 0.513043 & 7.9 & & & 18.295 & 15.461 & 37.882 \\
\hline HK-18 & 0.703331 & 0.513070 & 8.4 & 0.283176 & 14.3 & 18.174 & 15.445 & 37.738 \\
\hline HK-19 & 0.703292 & 0.513012 & 7.3 & 0.283187 & 14.7 & 18.310 & 15.460 & 37.907 \\
\hline HK-21 & 0.703324 & 0.513026 & 7.6 & & & 18.248 & 15.452 & 37.814 \\
\hline HK-22 & 0.703202 & 0.513065 & 8.3 & 0.283174 & 14.2 & 18.192 & 15.443 & 37.742 \\
\hline HK-23 & 0.703145 & 0.513056 & 8.2 & 0.283134 & 12.8 & 18.171 & 15.434 & 37.699 \\
\hline HK-25 & 0.703191 & 0.513057 & 8.2 & & & 18.206 & 15.449 & 37.770 \\
\hline HK-26 & 0.703183 & 0.513075 & 8.5 & & & 18.199 & 15.447 & 37.754 \\
\hline HK-28 & 0.703204 & 0.513044 & 7.9 & 0.283180 & 14.4 & 18.213 & 15.450 & 37.793 \\
\hline HK-29 & 0.703140 & 0.513064 & 8.3 & & & 18.171 & 15.440 & 37.712 \\
\hline HK-30 & 0.703195 & 0.513038 & 7.8 & 0.283150 & 13.4 & 18.203 & 15.444 & 37.756 \\
\hline HK-31 & 0.703199 & 0.513070 & 8.4 & & & 18.170 & 15.438 & 37.710 \\
\hline \multicolumn{9}{|c|}{ Haleakala Southwest Rift Zone (SWRZ; Sims et al., 1995; 1999; Stracke et al., 1999) ${ }^{\mathrm{h}}$ : } \\
\hline HK-02 & 0.70325 & 0.512228 & 7.7 & 0.283157 & 13.6 & 18.324 & 15.464 & 37.876 \\
\hline HK-04 & 0.70327 & 0.512220 & 7.5 & 0.283152 & 13.5 & 18.291 & 15.470 & 37.887 \\
\hline HK-06 & 0.70310 & 0.512259 & 8.3 & 0.283169 & 14.0 & 18.216 & 15.432 & 37.702 \\
\hline HK-10 & 0.70311 & 0.512242 & 7.9 & 0.283157 & 13.6 & 18.166 & 15.440 & 37.722 \\
\hline HK-11 & 0.70310 & 0.512255 & 8.2 & 0.283165 & 13.9 & & & \\
\hline
\end{tabular}

${ }^{\mathrm{a}} \mathrm{Sr}$ isotopes measured at WHOI using a Thermo Fisher Neptune MC-ICP-MS. Isotopic ratios normalized for instrumental mass fractionation relative to ${ }^{86} \mathrm{Sr}{ }^{88} \mathrm{Sr}=0.1194$. Results normalized to $\mathrm{NBS} 987=0.710240$. Internal precision for $\mathrm{Sr}$ was $5-10 \mathrm{ppm}(2 \sigma)$; external precision was estimated at $<30 \mathrm{ppm}(2 \sigma)$. Total procedural blanks for $\mathrm{Sr}$ were $<400 \mathrm{pg}$. Average measured value for NBS987 was $0.710244 \pm 0.000030(2 \sigma)$.

${ }^{\mathrm{b}} \mathrm{Nd}$ isotopes measured at WHOI using a Thermo Fisher Neptune MC-ICP-MS. Isotopic ratios normalized for instrumental mass fractionation relative to ${ }^{146} \mathrm{Nd} /{ }^{144} \mathrm{Nd}=0.7219$. Results normalized to LaJolla $=0.511847$. Internal precision for $\mathrm{Nd}$ was $5-10 \mathrm{ppm}(2 \sigma)$; external precision estimated at $<30 \mathrm{ppm}(2 \sigma)$. Total procedural blanks were $<100 \mathrm{pg}$. Average measured value for LaJolla was $0.511825 \pm 0.000008(2 \sigma)$.

${ }^{\mathrm{c}} \mathcal{E}_{\mathrm{Nd}}$ for Haleakala Crater samples calculated using $\varepsilon_{\mathrm{Nd}}(\mathrm{CHUR})=0.512638$. 
${ }^{\mathrm{d}} \mathrm{Hf}$ isotopes measured using the Lamont Isolab 54 Secondary Ionization mass spectrometer (England et al., 1992) at the National high Magnetic Field Laboratory. JMC-475 was used as a standard and the long term average for this standard of 0.2822 for

${ }^{176} \mathrm{Hf} /{ }^{177} \mathrm{Hf}$ was also obtained in this study. Hf isotope ratios are corrected to 0.282165 for JMC-475. External precision for Hf estimated at $<30 \mathrm{ppm}(2 \sigma)$. Total procedural blanks were $<30 \mathrm{pg}$.

${ }^{\mathrm{e}} \varepsilon_{\mathrm{Hf}}$ calculated using $\varepsilon_{\mathrm{Hf}}(\mathrm{CHUR})=0.282772$.

${ }^{\mathrm{f}} \mathrm{Pb}$ isotopes measured at WHOI using a Thermo Fisher Neptune MC-ICP-MS. Pb isotope compositions were normalized for instrumental mass bias relative to NBS/SRM $997{ }^{203} \mathrm{Tl} /{ }^{205} \mathrm{Tl}=0.41891$. NBS981 was analyzed as a bracketing standard (White et al., 2000); the following values for NBS981 from Todt et al. (1996) were used for normalization: ${ }^{206} \mathrm{~Pb} /{ }^{204} \mathrm{~Pb}=16.9356$, ${ }^{207} \mathrm{~Pb} /{ }^{204} \mathrm{~Pb}=15.4891$, and ${ }^{208} \mathrm{~Pb} /{ }^{204} \mathrm{~Pb}=36.7006$. The internal precision of $\mathrm{Pb}$ isotopic ratios (xxx/204) was 15-60 ppm. External reproducibility ranged from $75 \mathrm{ppm}(2 \sigma)$ for ${ }^{207} \mathrm{~Pb} /{ }^{206} \mathrm{~Pb}$ to $200 \mathrm{ppm}(2 \sigma)$ for ${ }^{208} \mathrm{~Pb} /{ }^{204} \mathrm{~Pb}$. The total procedural blank was $120-150 \mathrm{pg}$. Analyses of USGS standards AGV-1 gave ${ }^{206} \mathrm{~Pb} /{ }^{204} \mathrm{~Pb}=18.9414,{ }^{207} \mathrm{~Pb} /{ }^{204} \mathrm{~Pb}=15.6548$, and ${ }^{208} \mathrm{~Pb} /{ }^{204} \mathrm{~Pb}=38.5615$ and for BCR- $1{ }^{206} \mathrm{~Pb} /{ }^{204} \mathrm{~Pb}=18.8215,{ }^{207} \mathrm{~Pb} /{ }^{204} \mathrm{~Pb}=15.6356$, and ${ }^{208} \mathrm{~Pb} /{ }^{204} \mathrm{~Pb}=38.7309$.

${ }^{\mathrm{g}}$ See Hart et al. $(2004,2005)$ and Hart and Blusztajn (2006) for further details on Sr, Nd, and Pb isotopic methods.

${ }^{\mathrm{h}} \mathrm{Nd}$ and Sr isotopes for Haleakala SWRZ samples reported in Sims et al. $(1995 ; 1999) . \varepsilon_{\mathrm{Nd}}$ calculated using $\varepsilon_{\mathrm{Nd}}(\mathrm{CHUR})=0.511836$. These were measured at UC Berkeley and normalized to ${ }^{146} \mathrm{Nd} /{ }^{142} \mathrm{Nd}=0.636151$. Hf isotopes for SWRZ samples reported in Stracke et al. (1999). 
Table 4: U-series data for Hana Volcanics samples. ${ }^{\mathrm{a}, \mathrm{b}, \mathrm{c}}$

\begin{tabular}{|c|c|c|c|c|c|c|c|c|c|c|c|c|}
\hline & {$[\mathrm{Th}] \mu \mathrm{g} / \mathrm{g}^{\mathrm{e}}$} & {$[\mathrm{U}] \mu \mathrm{g} / \mathrm{g}^{\mathrm{e}}$} & {$\left[{ }^{226} \mathrm{Ra}\right] \mathrm{fg} / \mathrm{g}^{\mathrm{f}}$} & {$\left[{ }^{231} \mathrm{~Pa}\right] \mathrm{fg} / \mathrm{g}^{\mathrm{g}}$} & $\begin{array}{l}{ }^{230} \mathrm{Th} /{ }^{232} \mathrm{Th}\left(\times 10^{-6}\right) \\
\quad \pm 2 \sigma \operatorname{RSE}(\%)\end{array}$ & $\left({ }^{230} \mathrm{Th} /{ }^{232} \mathrm{Th}\right)^{\mathrm{d}}$ & $\left({ }^{230} \mathrm{Th} /{ }^{238} \mathrm{U}\right)^{\mathrm{d}}$ & $\left({ }^{226} \mathrm{Ra} /{ }^{230} \mathrm{Th}\right)_{\text {measured }}$ & $\left({ }^{226} \mathrm{Ra}{ }^{230} \mathrm{Th}\right)_{\text {age corr. }}$ & $\left({ }^{231} \mathrm{~Pa}{ }^{235} \mathrm{U}\right)$ & {$\left[{ }^{227} \mathrm{Ac}\right] \mathrm{fg} / \mathrm{g}^{\mathrm{h}}$} & $\left({ }^{227} \mathrm{Ac} /{ }^{231} \mathrm{~Pa}\right)$ \\
\hline \multicolumn{13}{|c|}{ Haleakala Crater: } \\
\hline HK-16 & 3.85 & 1.07 & 510 & & $5.773 \pm 0.1 \%$ & 1.069 & 1.267 & 1.113 & 1.213 & & & \\
\hline HK-17 & 3.68 & 1.06 & 454 & & $5.731 \pm 0.1 \%$ & 1.061 & 1.214 & 1.046 & 1.253 & & & \\
\hline HK-18 & 3.73 & 1.10 & 530 & 542 & $5.806 \pm 0.1 \%$ & 1.075 & 1.197 & 1.188 & 1.283 & 1.509 & 0.36 & $1.02^{\mathrm{i}}$ \\
\hline HK-19 & 3.97 & 1.06 & 492 & 552 & $5.756 \pm 0.1 \%$ & 1.065 & 1.315 & 1.045 & 1.252 & 1.599 & 0.36 & $1.00^{\mathrm{i}}$ \\
\hline HK-21 & 2.47 & 0.69 & 351 & 327 & $5.922 \pm 0.1 \%$ & 1.096 & 1.301 & 1.167 & 1.273 & 1.466 & 0.21 & $0.99^{\mathrm{i}}$ \\
\hline HK-22 & 2.45 & 0.72 & 342 & 493 & $5.724 \pm 0.2 \%$ & 1.059 & 1.197 & 1.184 & 1.287 & 2.115 & 0.33 & 1.03 \\
\hline HK-23 & 4.19 & 1.21 & 587 & & $5.763 \pm 0.1 \%$ & 1.067 & 1.218 & 1.179 & 1.259 & & & \\
\hline HK-25 & 5.41 & 1.59 & 707 & & $5.708 \pm 0.1 \%$ & 1.057 & 1.181 & 1.113 & 1.250 & & & \\
\hline HK-26 & 2.62 & 0.77 & 358 & & $5.705 \pm 0.1 \%$ & 1.056 & 1.184 & 1.165 & 1.250 & & & \\
\hline HK-28 & 2.57 & 0.74 & 347 & & $5.772 \pm 0.2 \%$ & 1.068 & 1.222 & 1.137 & 1.204 & & & \\
\hline HK-29 & 3.89 & 1.12 & 551 & & $5.826 \pm 0.1 \%$ & 1.078 & 1.231 & 1.180 & 1.271 & & & \\
\hline HK-30 & 4.25 & 1.22 & 560 & & $5.759 \pm 0.1 \%$ & 1.066 & 1.224 & 1.111 & 1.165 & & & \\
\hline HK-31 & 3.97 & 1.11 & 560 & & $5.826 \pm 0.1 \%$ & 1.078 & 1.271 & 1.177 & 1.268 & & & \\
\hline \multicolumn{13}{|l|}{ Standards ${ }^{\mathrm{j}}$ : } \\
\hline ATHO & 7.44 & 2.26 & 844 & & $5.495 \pm 0.1 \%$ & 1.015 & 1.104 & 1.003 & & & & \\
\hline TML & 30.50 & 10.79 & 3604 & & $5.820 \pm 0.2 \%$ & 1.070 & 0.998 & 0.989 & & & & \\
\hline BCR-2 & 5.89 & 1.71 & 565 & 555 & $4.740 \pm 0.2 \%$ & 0.874 & 0.992 & 0.986 & & 0.997 & 0.36 & 0.99 \\
\hline BHVO- $1^{\mathrm{k}}$ & & & & 163 & & & & & & & 0.11 & 1.02 \\
\hline \multicolumn{13}{|c|}{ a ( ) denotes activity } \\
\hline \multicolumn{13}{|c|}{${ }^{b} \lambda 238=1.551 \times 10^{-10} \mathrm{yr}^{-1} ; \lambda 232=4.948 \times 10^{-11} \mathrm{yr}^{-1} ; \lambda 226=4.331 \times 10^{-4} \mathrm{yr}^{-1} ; \lambda 231=2.115 \times 10^{-5} \mathrm{yr}^{-1} ; \lambda 235=9.8485 \times 10^{-10} \mathrm{yr}^{-1}(\mathrm{Jaffey}$ et al., 1971; Le Roux and Glendenin, 1963 ; } \\
\hline \multirow{2}{*}{\multicolumn{13}{|c|}{$\begin{array}{l}\text { Holden, 1990; Tuli, 2000; Robert et al., 1969). } 2 \sigma \text { total errors are }<2.2 \% \text { for }[\mathrm{U}],<1.6 \% \text { for }[\mathrm{Th}],<3.5 \% \text { for }[\mathrm{Ra}] \text { and }<2.4 \% \text { for }[\mathrm{Pa}] \text {. These errors include uncertainties in } \\
\text { spike calibrations as well as measurement error and uncertainty in standards against which instrument measurements were calibrated. These errors do not include }\end{array}$}} \\
\hline & & & & & & & & & & & & \\
\hline \multicolumn{13}{|c|}{ uncertainties in $\lambda 238(0.07 \%), \lambda 232(0.5 \%), \lambda 226(0.4 \%), \lambda 231(0.04 \%)$ or $\lambda 235(0.07 \%)$} \\
\hline \multicolumn{13}{|c|}{${ }^{\mathrm{c}}$ Activity ratios calculated using $\lambda 230=9.158 \times 10^{-6} \mathrm{yr}^{-1}$ (Cheng et al., 2000) and $\lambda 232=4.948 \times 10^{-11} \mathrm{yr}^{-1}$ (Le Roux and Glendenin, 1963 ). $2 \sigma$ errors range from $0.4 \%$ to $1 \%$} \\
\hline \multicolumn{13}{|c|}{ and do not include uncertainties in $\lambda 230(0.4 \%)$ or $\lambda 232(0.5 \%)$. } \\
\hline \multirow{2}{*}{\multicolumn{13}{|c|}{$\begin{array}{l}\text { IIsotopic compositions were measured with a Thermo Fisher Neptune MC-ICP-MS at WHOI. }{ }^{232} \mathrm{Th} \text { and }{ }^{238} \mathrm{U} \text { were measured on a Faraday cup and }{ }^{230} \mathrm{Th} \text { on an axial, discrete } \\
\text { dynode ion counter with a repelling potential quadrupole (RPQ). Abundance sensitivity over } 2 \mathrm{AMU} \text { at } 85 \% \text { transmission was } \sim 50 \text { ppb. An exponential correction was used }\end{array}$}} \\
\hline & & & & & & & & & & & & \\
\hline \multicolumn{13}{|c|}{ to correct for the tailing of ${ }^{232} \mathrm{Th}$ on ${ }^{230} \mathrm{Th}$. Use of UCSC Th 'A' for Th-bracketing results in inter-day reproducibility of $0.4-1.5 \%(2 \sigma) .{ }^{236} \mathrm{U} /{ }^{238} \mathrm{U}$ ratios of U010 were } \\
\hline \multicolumn{13}{|c|}{ measured to correct for mass bias drift and to calibrate SEM yield. Standard-sample-standard bracketing was used for uranium analyses. } \\
\hline \multicolumn{13}{|c|}{${ }^{\mathrm{e}} \mathrm{U}$ and $\mathrm{Th}$ concentrations were measured by isotope dilution using a Thermo Fisher Element 2 high resolution sector-field ICP-MS at WHOI. Mass fractionation was } \\
\hline \multicolumn{13}{|c|}{ corrected by sample-standard bracketing with NBL-112A, using a linear interpolation of ${ }^{235} \mathrm{U} /{ }^{238} \mathrm{U}$ measurements of the standard. } \\
\hline \multicolumn{13}{|c|}{${ }^{\mathrm{f}}{ }^{226} \mathrm{Ra}$ concentrations were analyzed by isotope dilution mass spectrometry at WHOI with a Thermo Fisher Neptune MC-ICP-MS. Aliquots were spiked with ${ }^{228}$ Ra to attain } \\
\hline${ }^{226} \mathrm{Ra} /{ }^{228} \mathrm{Ra}$ & 10. Measurem & hent errors do & not include the & uncertainty in $\lambda$ & 226 , which is $0.4 \%$. & & & & & & & \\
\hline
\end{tabular}


with NBS 960.

${ }^{\mathrm{h}} \mathrm{A}$ value of $20.0 \mathrm{dpm} / \mathrm{g}$ was obtained for IAEA liquid standard (certified value of $19.5 \mathrm{dpm} / \mathrm{g}$ ).

${ }^{\mathrm{i}}\left({ }^{227} \mathrm{Ac}{ }^{231} \mathrm{~Pa}\right)$ is an average of 2 analyses of HK-18 $(1.025 ; 1.011)$, of 2 analyses for HK-19 $(0.996 ; 0.996)$, and of 4 analyses for HK-21 $(2 \sigma \mathrm{SD}=0.042)$.

${ }^{\mathrm{j}} \mathrm{ATHO}, \mathrm{TML}$, and BCR-2 rock standards were measured at WHOI in replicate $(\mathrm{N})$ for quality assurance by MC-ICP-MS over the same time interval as the Haleakala Crater samples analyzed in this study. Averages of replicate measurements are shown in the table. For ATHO, N=8 for [Th], [U],

$\left({ }^{230} \mathrm{Th} /{ }^{232} \mathrm{Th}\right)$, and $\left({ }^{230} \mathrm{Th} /{ }^{238} \mathrm{U}\right) ; \mathrm{N}=15$ for measured ${ }^{230} \mathrm{Th} /{ }^{232} \mathrm{Th} ; \mathrm{N}=3$ for $[\mathrm{Ra}]$ and $\left({ }^{226} \mathrm{Ra} /{ }^{230} \mathrm{Th}\right)$. For TML N=12 for $[\mathrm{Th}],[\mathrm{U}],\left({ }^{230} \mathrm{Th} /{ }^{232} \mathrm{Th}\right)$, and $\left({ }^{230} \mathrm{Th} /{ }^{238} \mathrm{U}\right) ;$

$\mathrm{N}=15$ for measured ${ }^{230} \mathrm{Th} /{ }^{232} \mathrm{Th} ; \mathrm{N}=5$ for $[\mathrm{Ra}]$ and $\left({ }^{226} \mathrm{Ra}{ }^{230} \mathrm{Th}\right)$. For BCR-2, $\mathrm{N}=6$ for $[\mathrm{Th}],[\mathrm{U}],\left({ }^{230} \mathrm{Th} /{ }^{232} \mathrm{Th}\right)$ and $\left({ }^{230} \mathrm{Th} /{ }^{238} \mathrm{U}\right) ; \mathrm{N}=10$ for measured ${ }^{230} \mathrm{Th} /{ }^{232} \mathrm{Th} ; \mathrm{N}=6$

for $[\mathrm{Ra}]$ and $\left({ }^{226} \mathrm{Ra} /{ }^{230} \mathrm{Th}\right)$. Sims et al. (2008b) compare analyses of synthetic and rock standards analyzed at WHOI with those of other laboratories.

${ }^{\mathrm{k}}\left({ }^{227} \mathrm{Ac}{ }^{231} \mathrm{~Pa}\right)$ for BHVO-1 is average of 3 analyses $(2 \sigma \mathrm{SD}=0.088)$. 
Table 5: Summary of solid mantle upwelling velocities and porosity from contour plots generated with chromatographic porous flow model (Spiegelman, 2000) using four different sets of D values for $\mathrm{U}$ and Th. D values for Ra and Pa from Lundstrom et al. (1994) were used for all models.

\begin{tabular}{cccc}
\hline & Tholeiites (Kilauea and Mauna Loa) & Alkali basalts (Hualalai) & Basanites (Haleakala) \\
$50 \mathrm{~km}$ melt column; $15 \%$ melting & $10 \mathrm{~km}$ melt column; $3 \%$ melting & $10 \mathrm{~km}$ melt column; $3 \%$ melting \\
\hline
\end{tabular}

\section{Inverted D values (Sims et al., 1999) garnet peridotite}

Maximum porosity

Solid mantle upwelling velocity

\section{Salters and Longhi, 1999 \\ garnet peridotite}

Maximum porosity

Solid mantle upwelling velocity

\section{Lundstrom et al., 1994 garnet peridotite}

Maximum porosity

Solid mantle upwelling velocity

\section{Elkins et al., 2008}

\section{garnet pyroxenite}

Maximum porosity

Solid mantle upwelling velocity

$$
0.5-0.6 \%
$$

$10-20 \mathrm{~cm} / \mathrm{yr}$

$2-3 \%$

$50-80 \mathrm{~cm} / \mathrm{yr}$

$1-2 \%$

$20-30 \mathrm{~cm} / \mathrm{yr}$

$5-7 \%$ to no convergence*

$90-200 \mathrm{~cm} / \mathrm{yr}$ to no convergence*
$0.2-0.3 \%$

$1-2 \mathrm{~cm} / \mathrm{yr}$

$1-2 \%$

$2-4 \mathrm{~cm} / \mathrm{yr}$

$0.5-0.7 \%$

$1-2 \mathrm{~cm} / \mathrm{yr}$

*Elkins et al. (2008) provide a range for $\mathrm{U}$ and Th partition coefficients for garnet pyroxenite. For modeled tholeiites, the high end of the range produced no
convergence and the low end of the range indicated maximum porosities of $5-7 \%$ and solid mantle upwelling velocity of $90-200 \mathrm{~cm} / \mathrm{yr}$.

*Elkins et al. (2008) provide a range for $\mathrm{U}$ and Th partition coefficients for garnet pyroxenite. For modeled tholeiites, the high end of the
convergence and the low end of the range indicated maximum porosities of 5-7\% and solid mantle upwelling velocity of $90-200 \mathrm{~cm} / \mathrm{yr}$.

$1-2 \%$

$1-2 \mathrm{~cm} / \mathrm{yr}$

no convergence

no convergence

$0.1-0.3 \%$

$0.7-1.0 \mathrm{~cm} / \mathrm{yr}$

no convergence

no convergence 


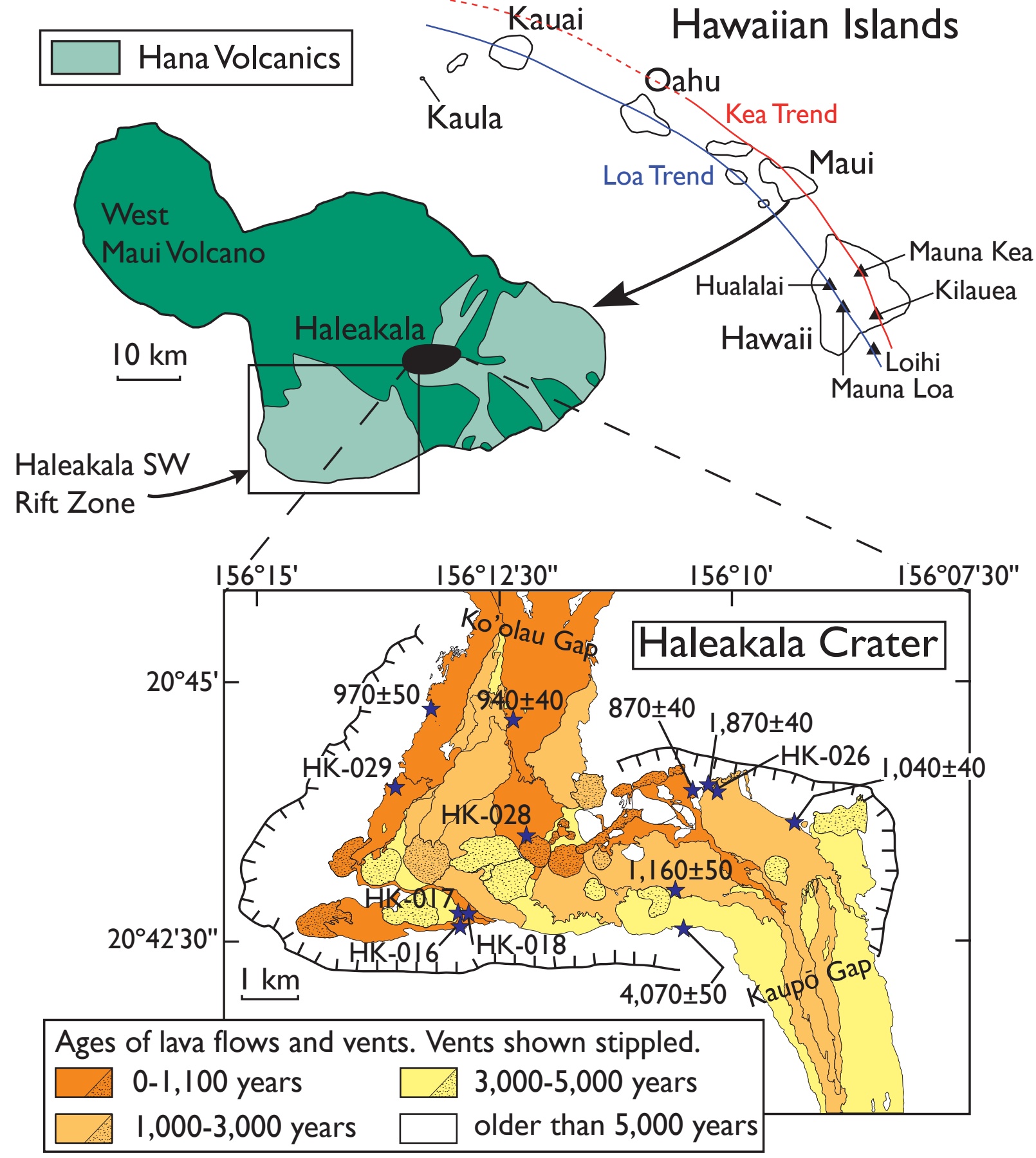

Figure 1 
Figure 2

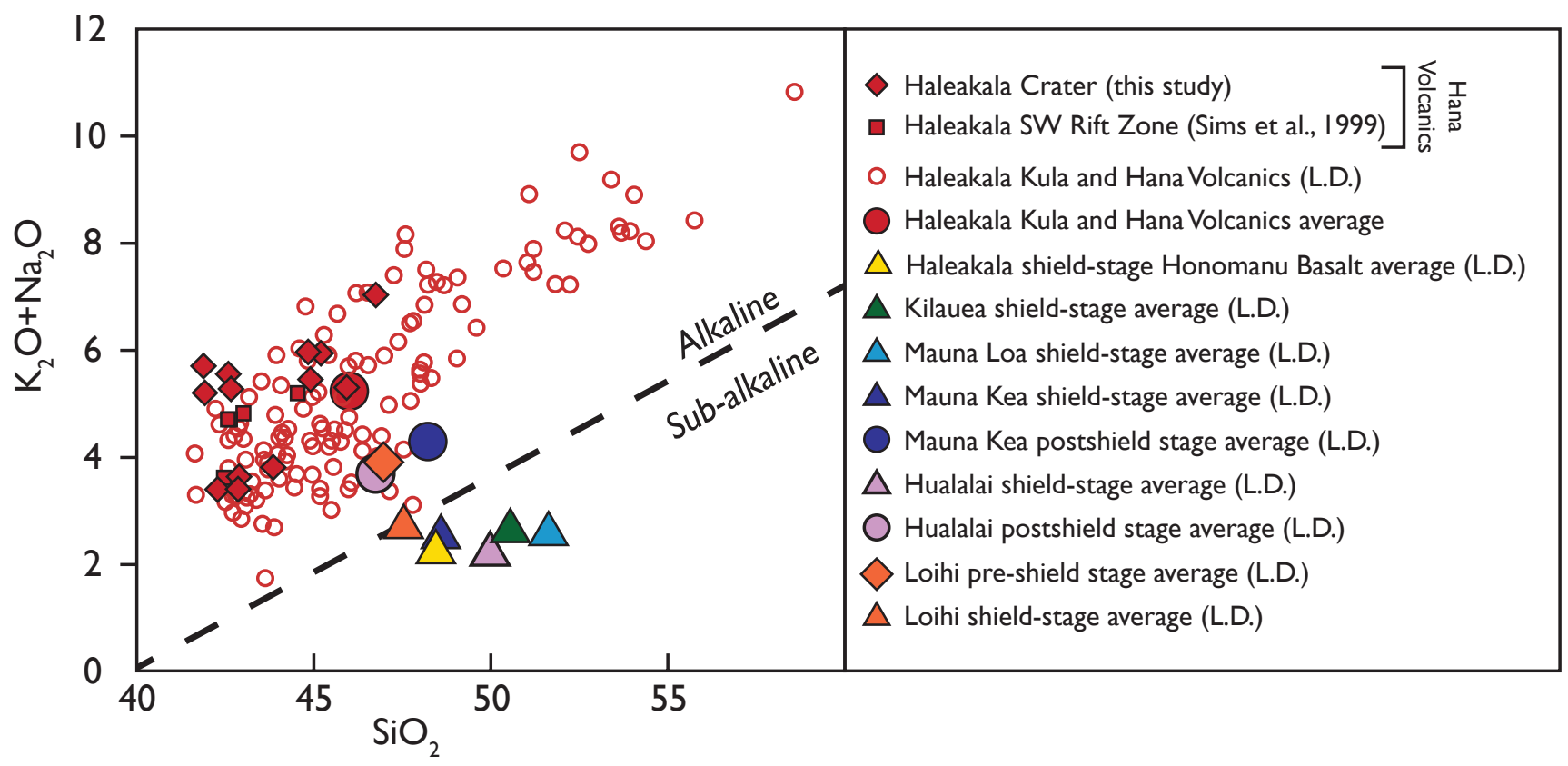

Figure 2 


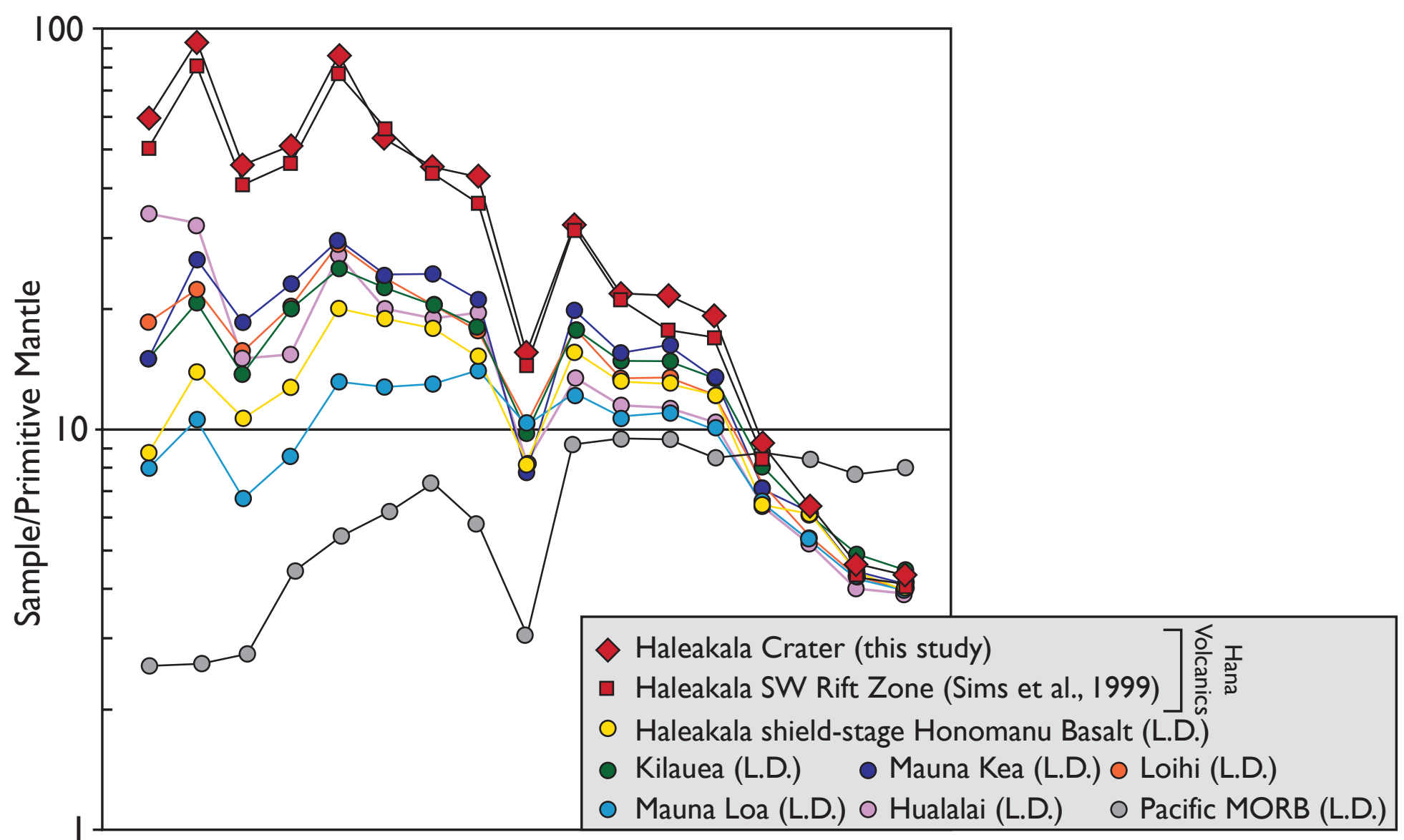

$\mathrm{Rb}$ Ba Th $U$ Nb La Ce Sr Pb Nd Sm Hf Eu Dy Y Yb Lu

Figure 3 


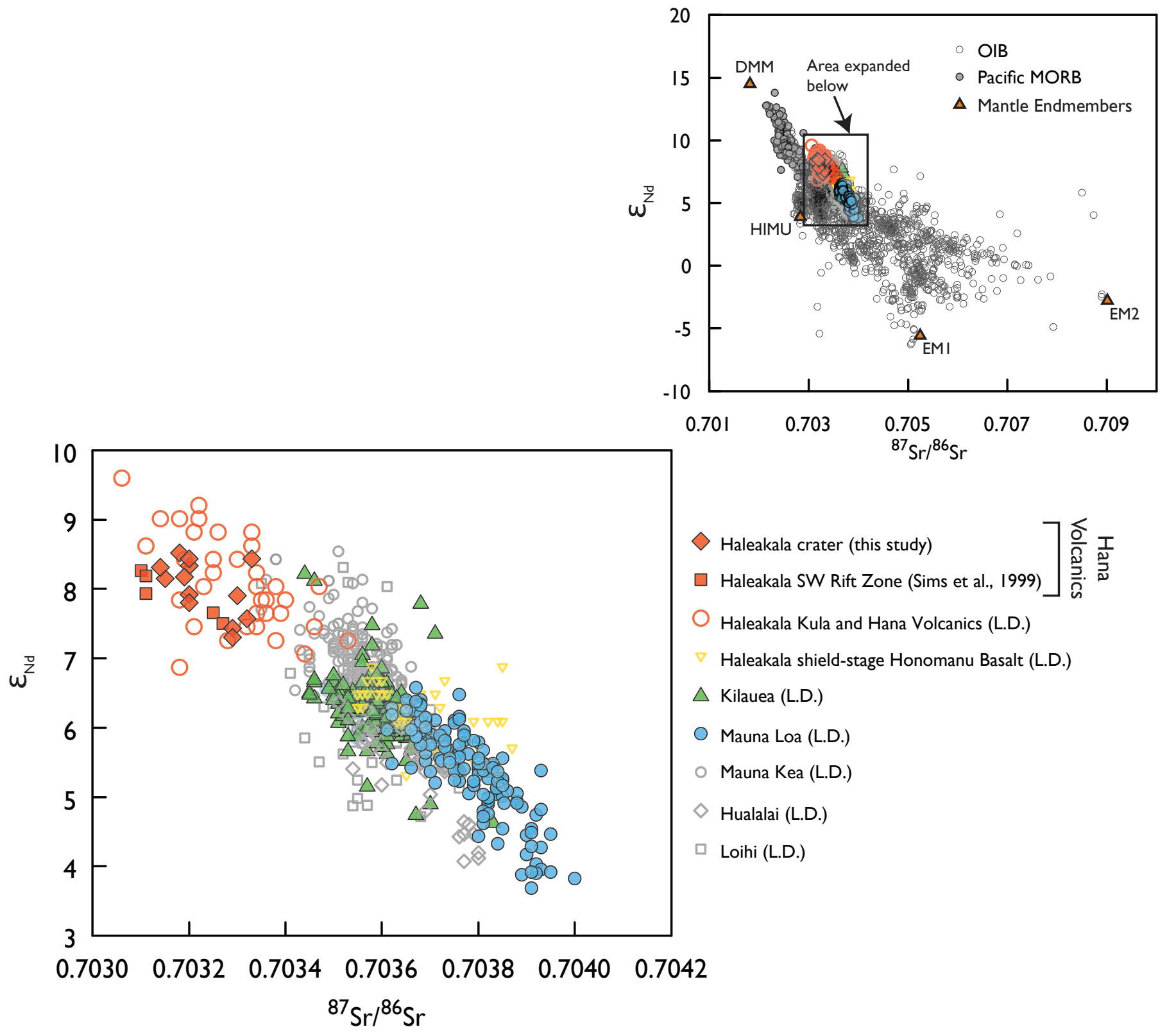

Figure 4 
Figure 5
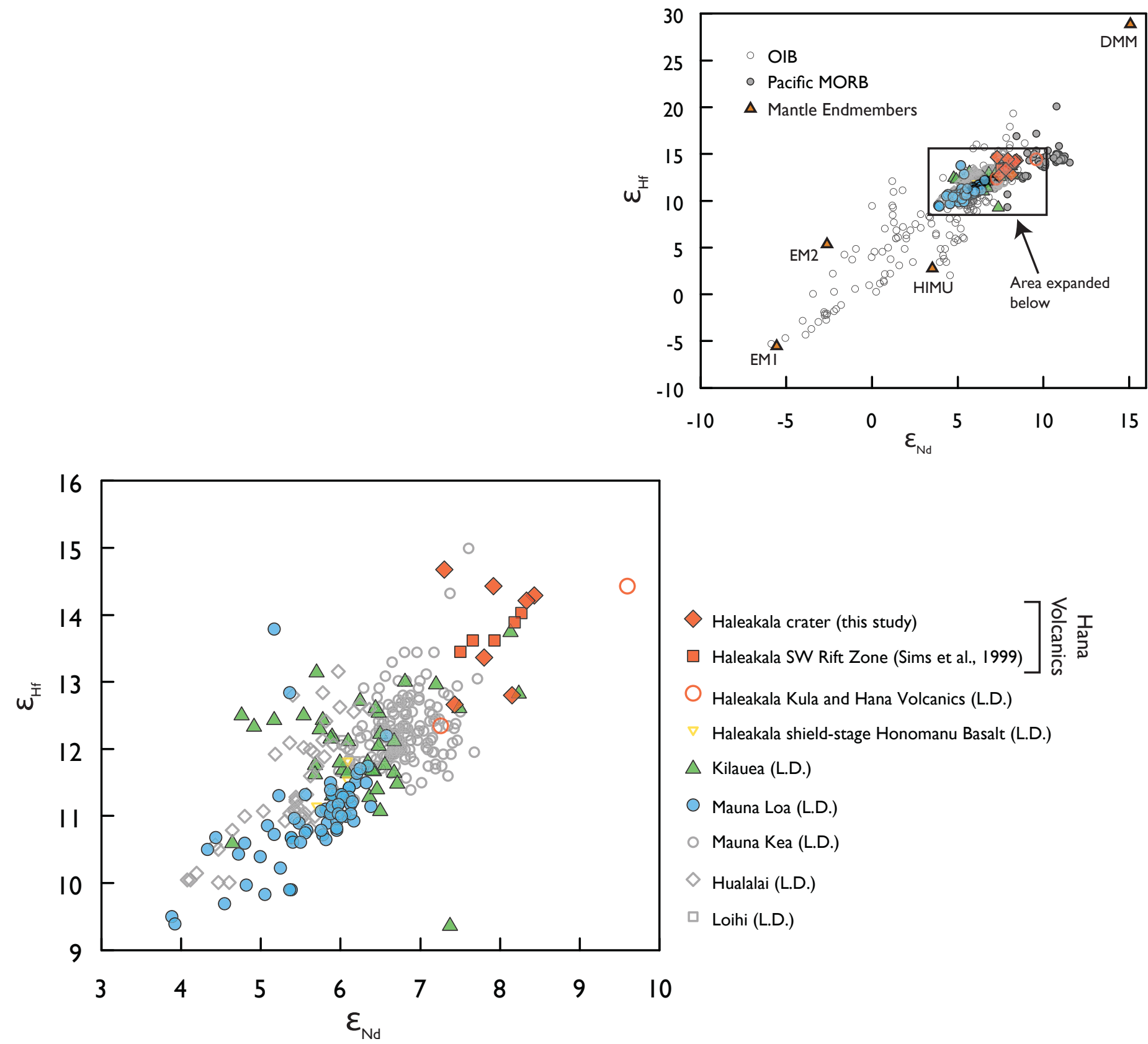

Figure 5

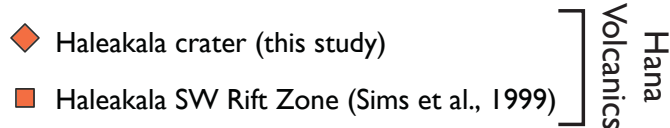

Haleakala Kula and Hana Volcanics (L.D.)

7 Haleakala shield-stage Honomanu Basalt (L.D.)

$\triangle$ Kilauea (L.D.)

Mauna Loa (L.D.)

- Mauna Kea (L.D.)

$\diamond$ Hualalai (L.D.)

$\square$ Loihi (L.D.) 


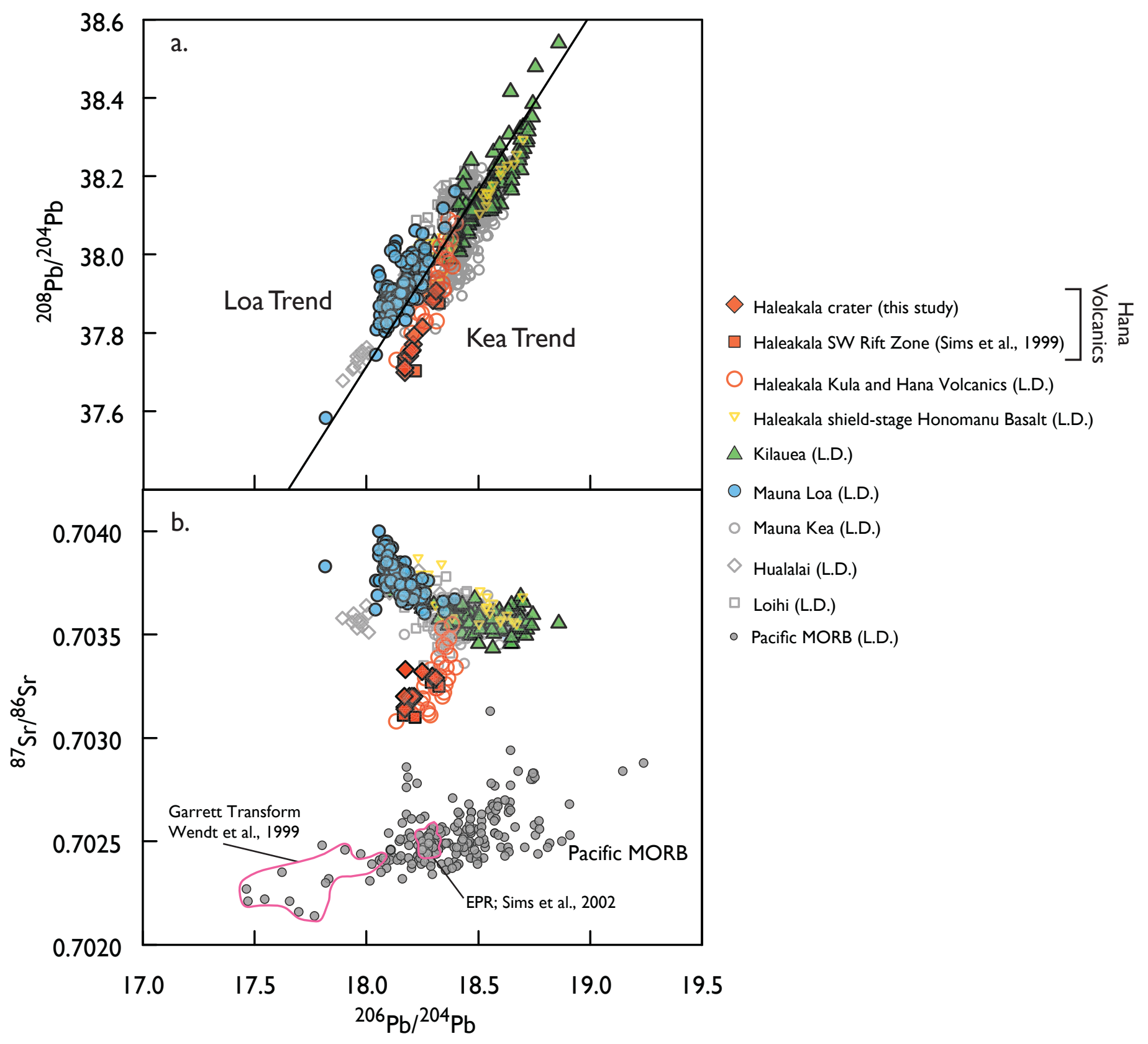

Figure 6 


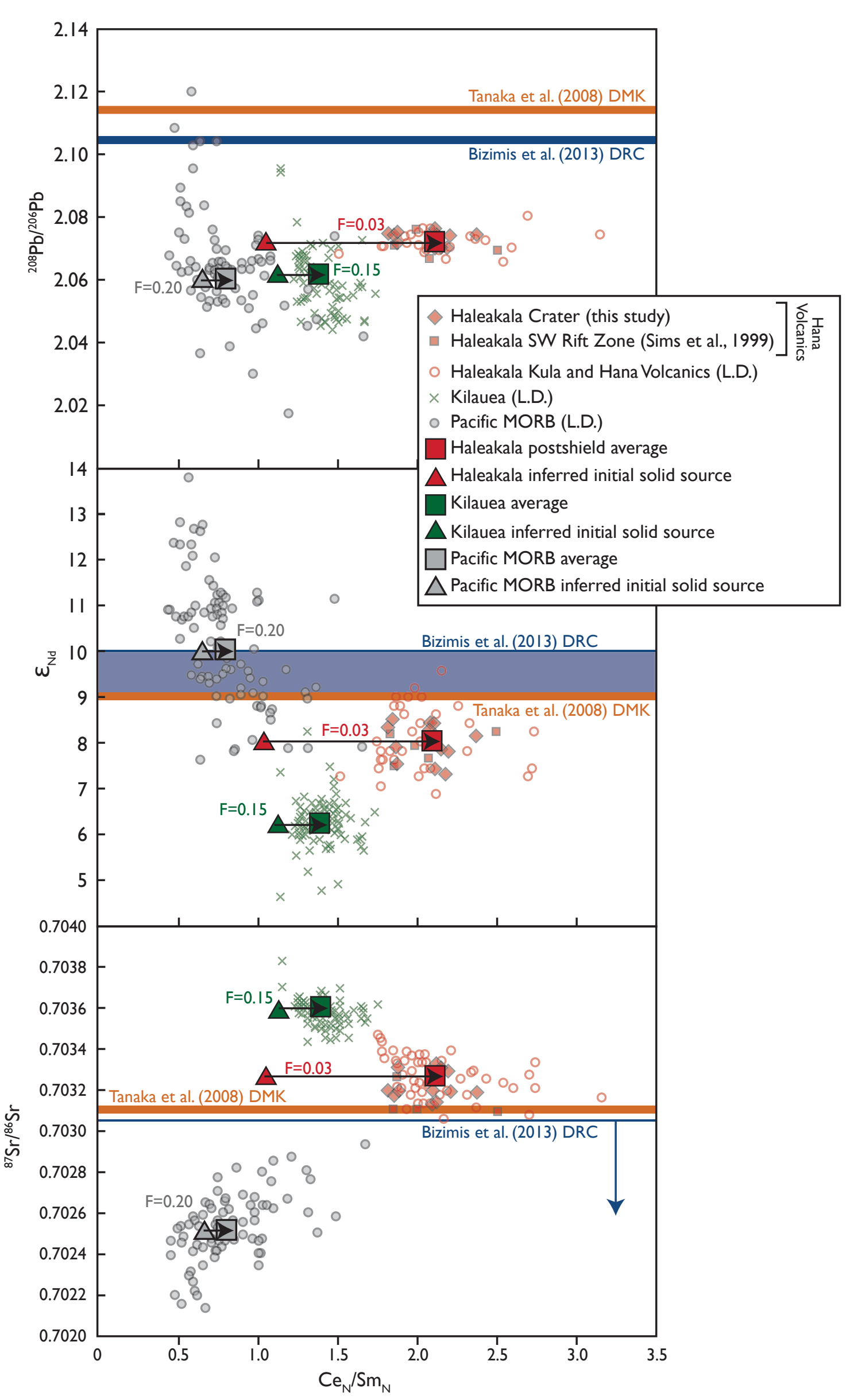

Figure 7 


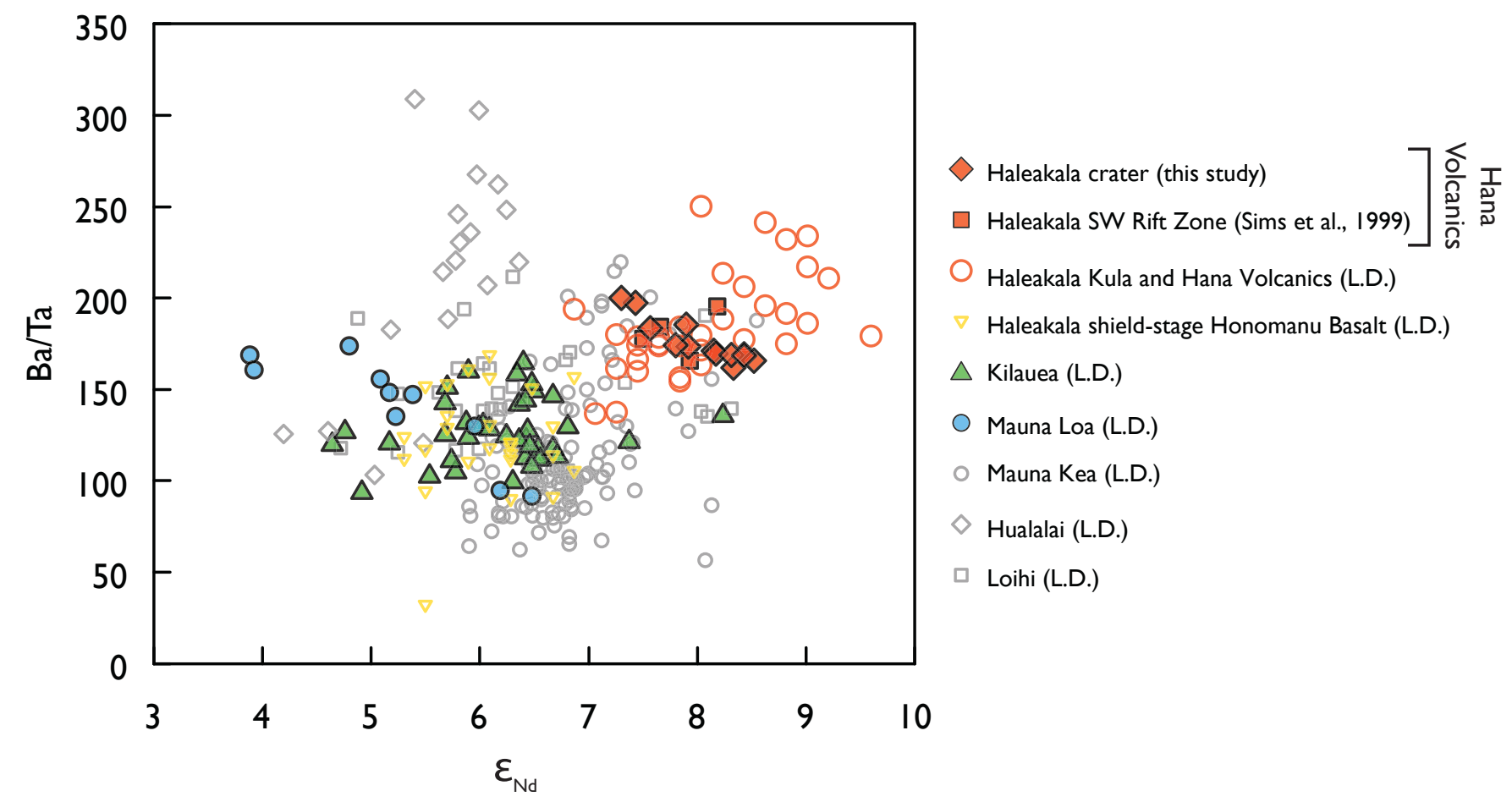

Figure 8 
Figure 9

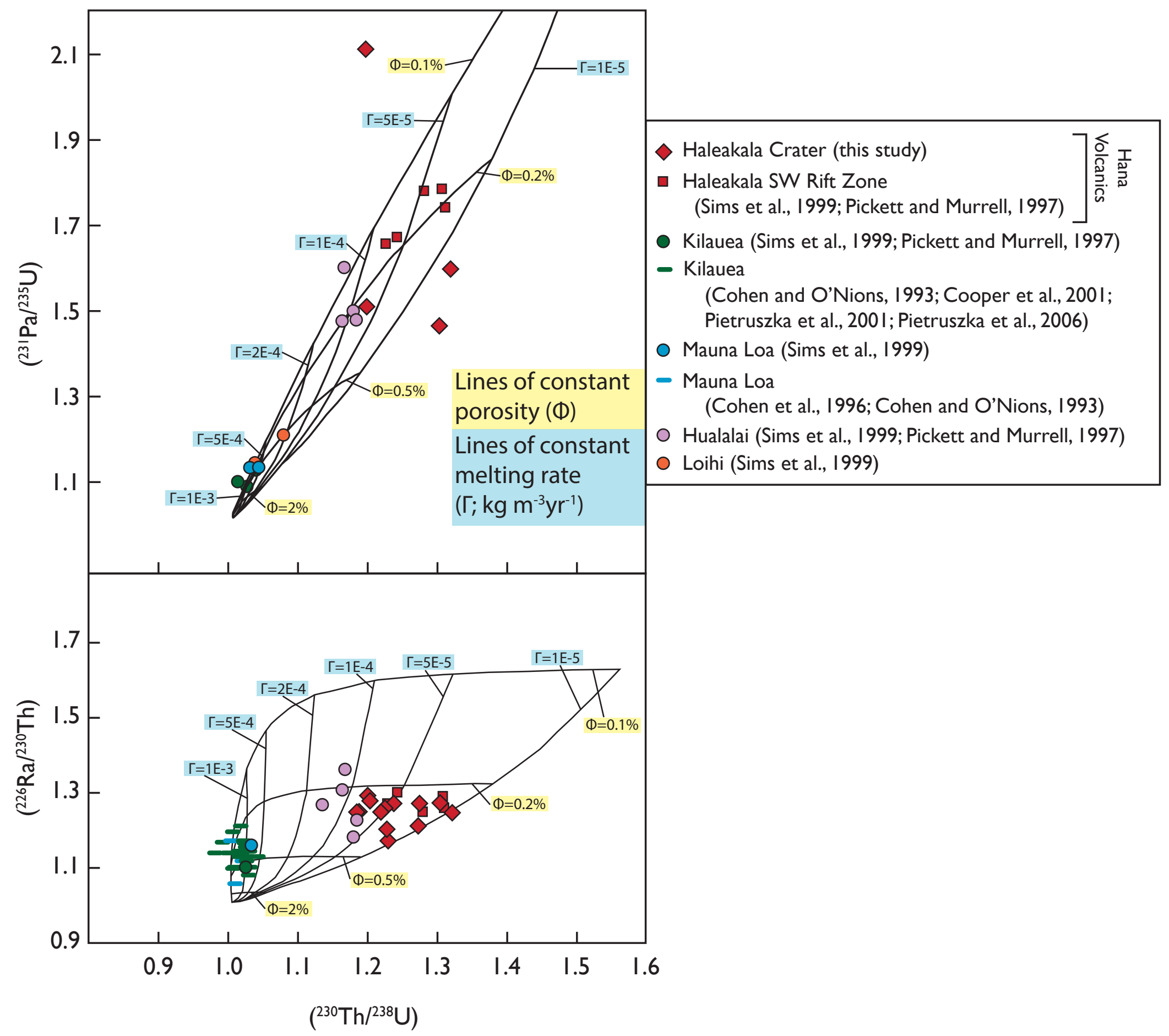

Figure 9 
a.) Kilauea and Mauna Loa Tholeiites $50 \mathrm{~km}$ melt column; I5\% melting

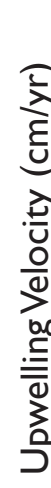

0.1

$0.1 \%$

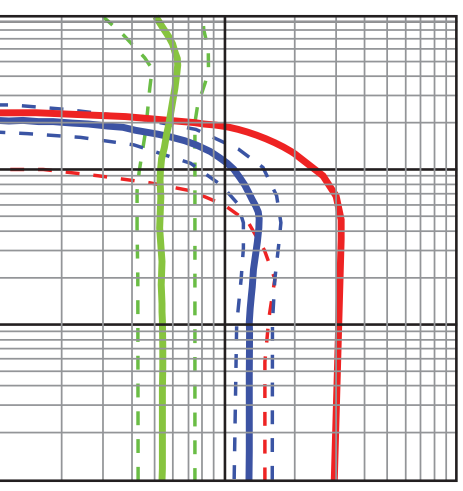

$$
\text { Porosity }
$$

$$
\begin{aligned}
& -\left({ }^{30} \mathrm{Th}^{238} \mathrm{U}\right)-\text { ave. }=1.03-\mathrm{n}=43- \\
& -\left({ }^{26} \mathrm{Ra}{ }^{230} \mathrm{Th}\right)-\text { ave. }=1.13-\mathrm{n}=27- \\
& -\left({ }^{231} \mathrm{~Pa}{ }^{235} \mathrm{U}\right)-\text { ave. }=1.12-\mathrm{n}=5-
\end{aligned}
$$

b.) Hualalai Alkali Basalts

$10 \mathrm{~km}$ melt column; $3 \%$ melting

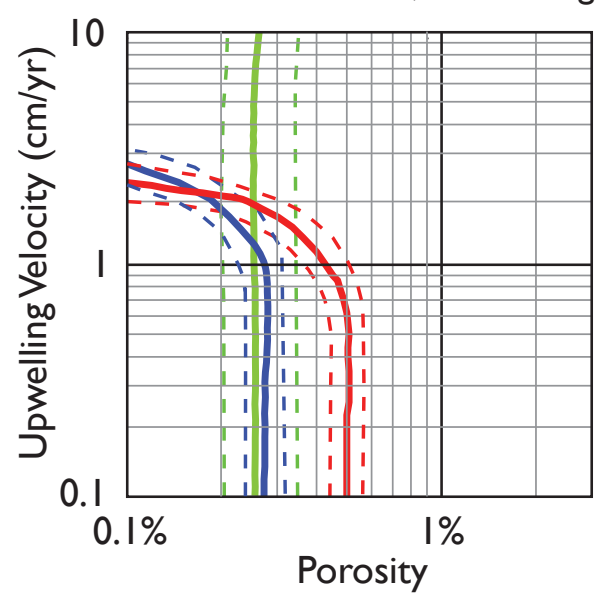

$\left.-{ }^{230} \mathrm{Th}^{238} \mathrm{U}\right)-$ ave. $=1.17-\mathrm{n}=5-$
$\left.-{ }^{226} \mathrm{Ra}^{230} \mathrm{Th}\right)-$ ave. $=1.27-\mathrm{n}=5-$
$-\left({ }^{231} \mathrm{~Pa}{ }^{235} \mathrm{U}\right)-$ ave. $=1.52-\mathrm{n}=4-$ c.) Haleakala Basanites

$10 \mathrm{~km}$ melt column; $3 \%$ melting

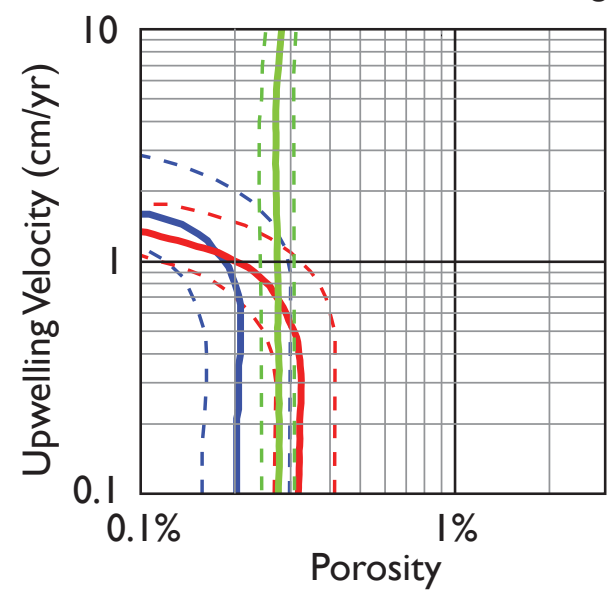

$-\left({ }^{30} \mathrm{Th}^{238} \mathrm{U}\right)-$ ave. $=1.24-\mathrm{n}=18-$
$-\left({ }^{26} \mathrm{Ra}{ }^{230} \mathrm{Th}\right)-$ ave. $=1.26-\mathrm{n}=18-$
$-\left({ }^{31} \mathrm{~Pa}{ }^{235} \mathrm{U}\right)-$ ave. $=1.70-\mathrm{n}=9-$

Figure 10 


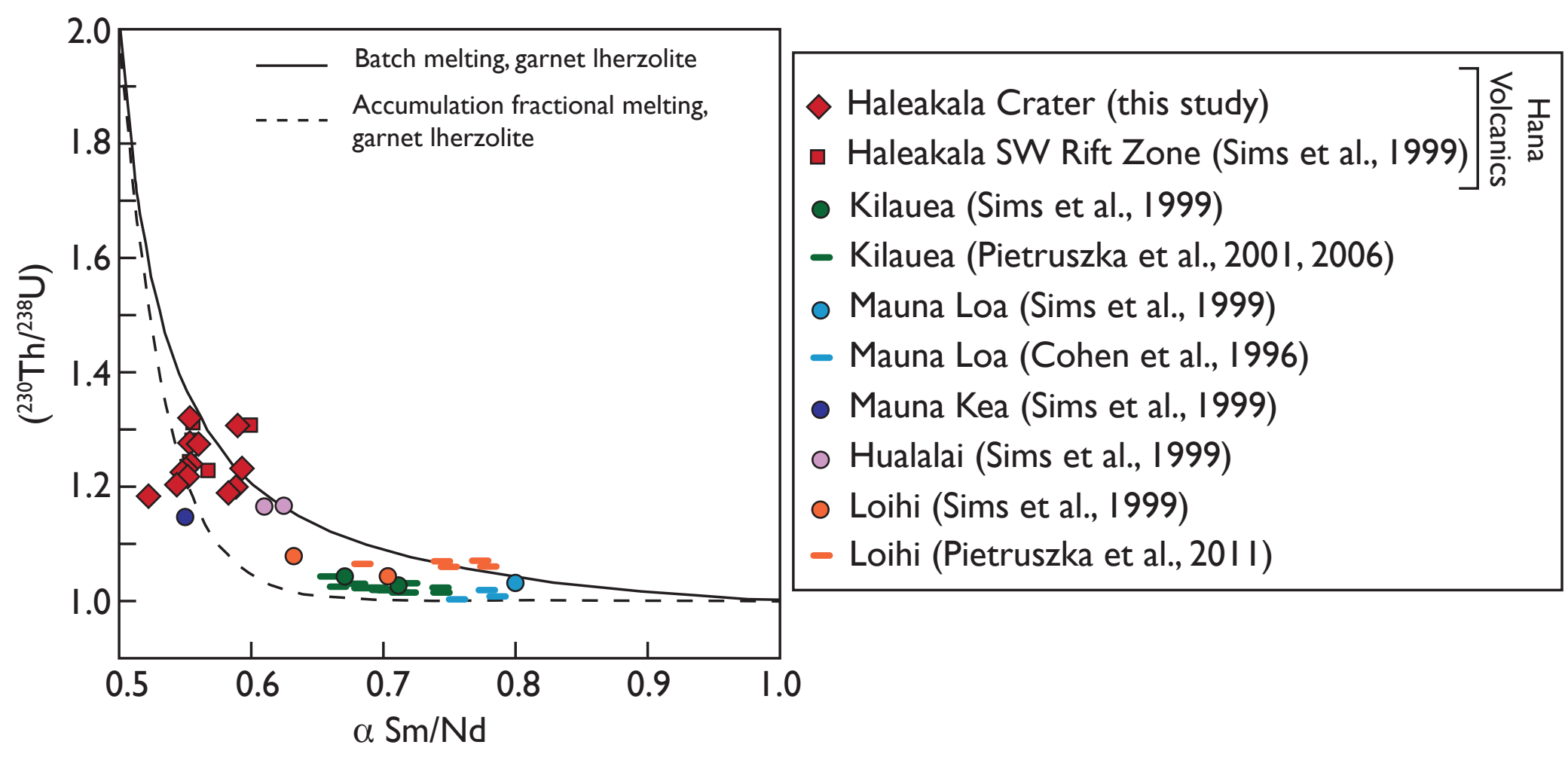

Figure 11 


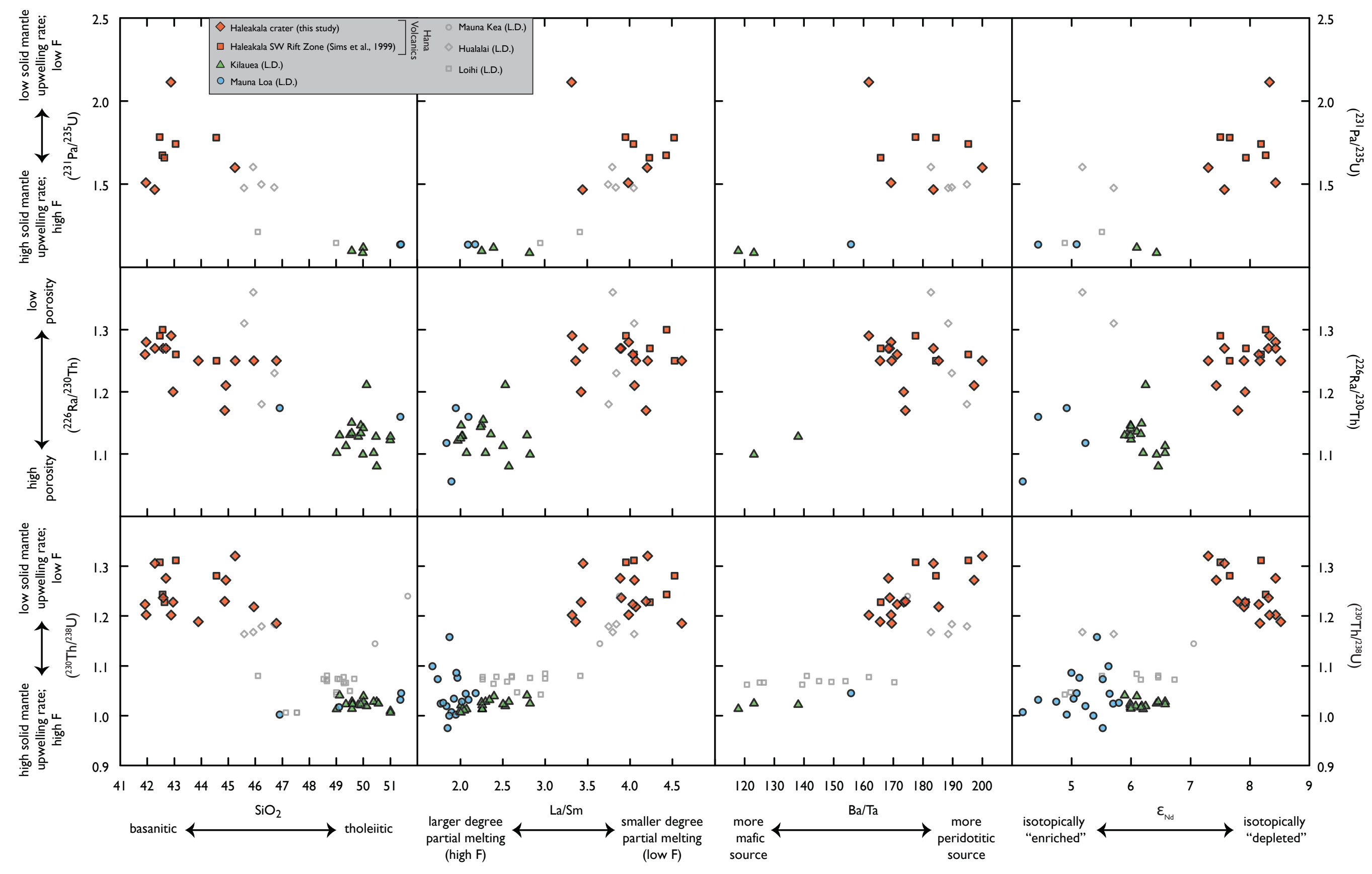

Figure 12 